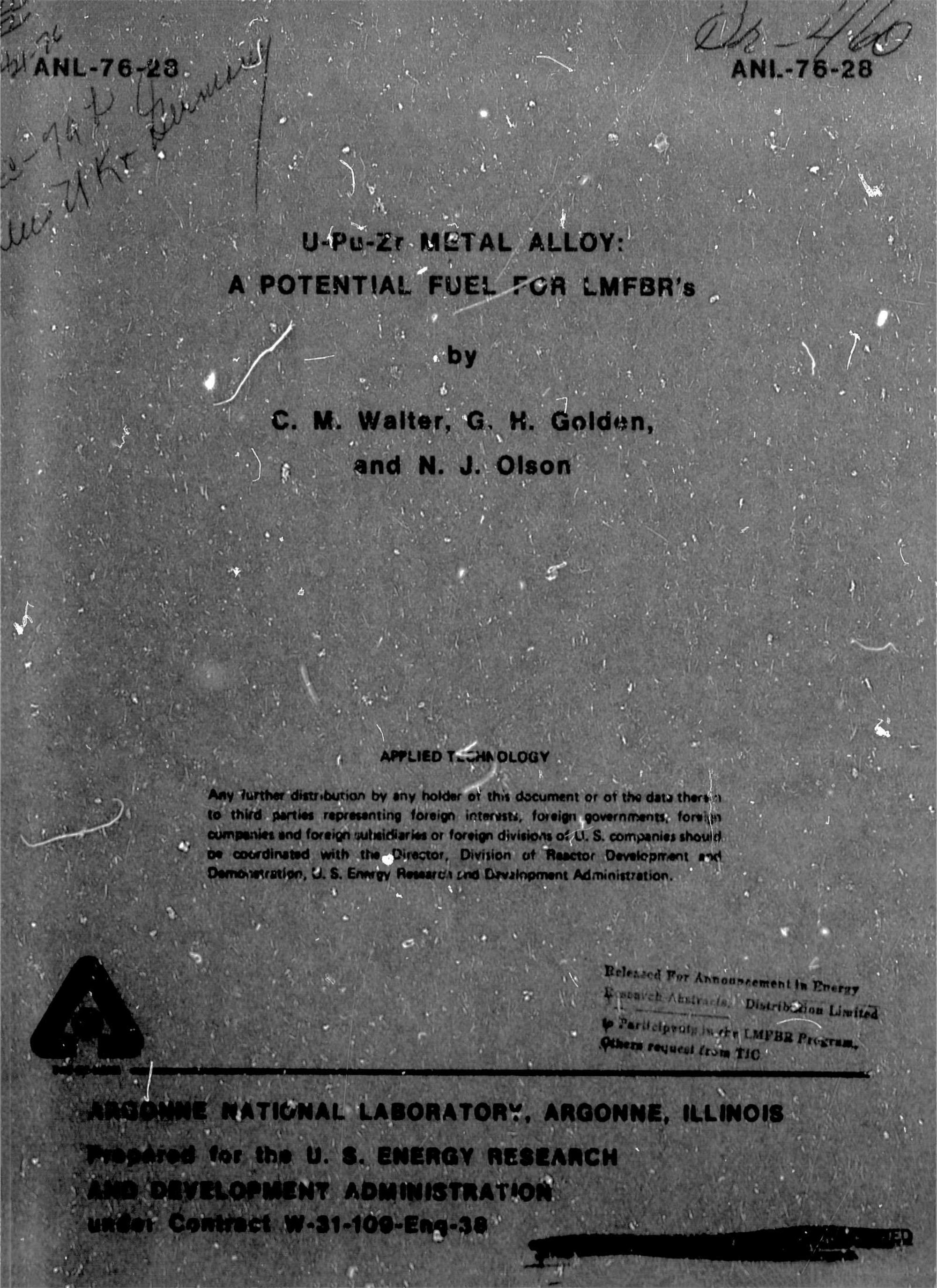


c

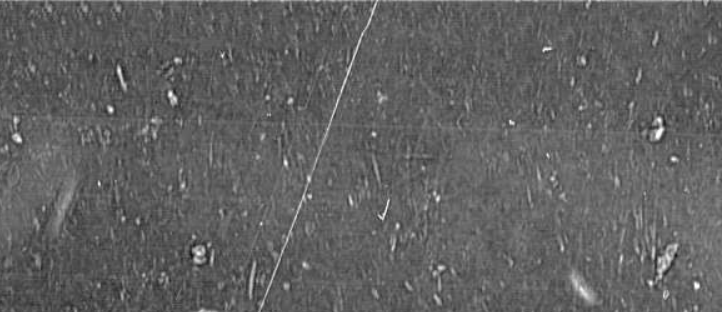

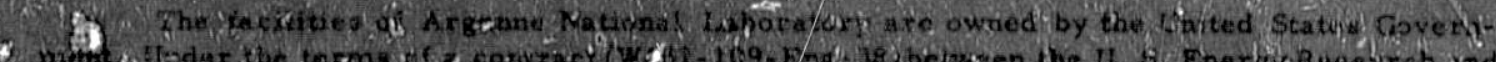

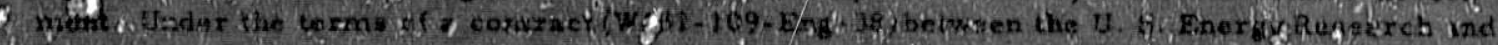

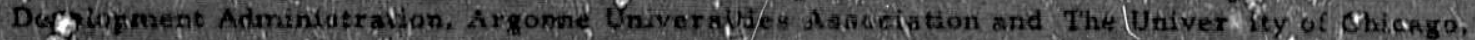

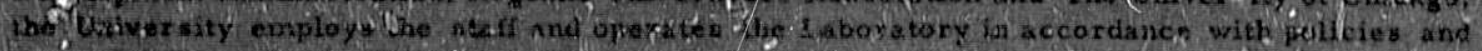

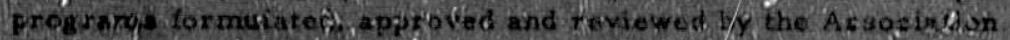
(4)

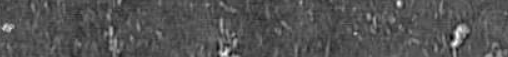

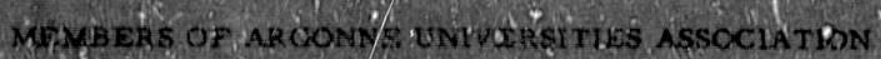

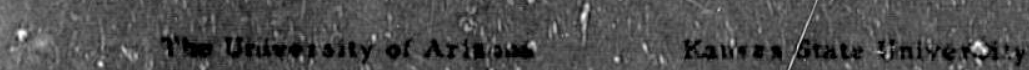

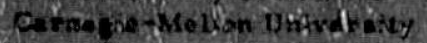

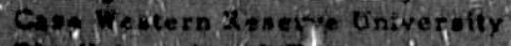
7W. Univer ally of 9 licigo Linizin vivy of Cthpthnati ulinote pyetitute.por Tecrnolony

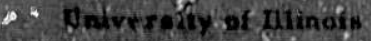
Indkese ohive foity lowe gats thiveraity

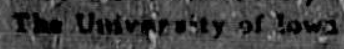

s

\section{8} This U. Sparatiy of kansed Layul Heivardity Marq/uette Unisidy nity Mic/igan soxte Univerkity. Th. Whitviritity of Wichigan Ui Averpity of Aqunesotol.

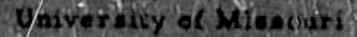
Joxtawantory Univeraity 1. Univergity of Nosre Bince
Tho Onio Stote, Univereatity

Dhat Indrorisity

Thy Poningylvonia State Univesinity

Purglue Nnivernity

Saint Lotí Un'vecosity

Southern Alinois Unvordity.

The Univexsity of Texas at Aur.an Washingon UNy expaty

Vaxper State Univeroity.

Tha Unirencetcy of Wisconelo

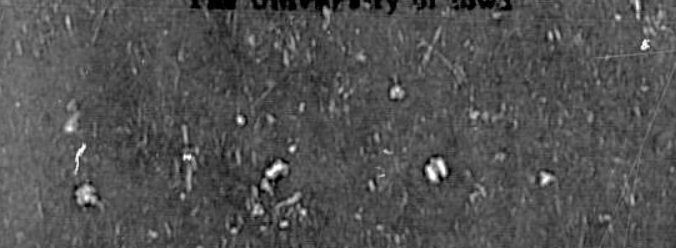

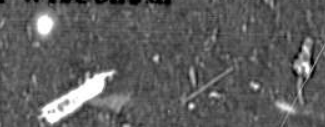

\section{y. $y$ noticen}

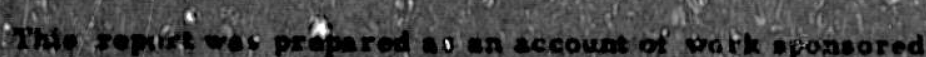

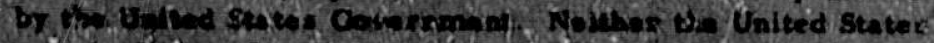

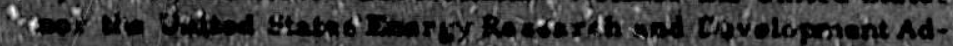

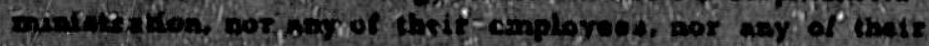

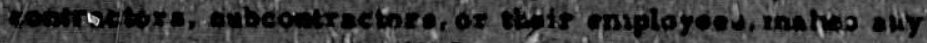

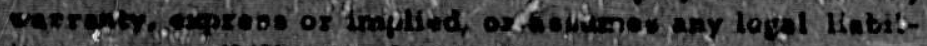

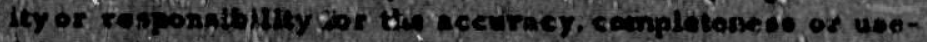

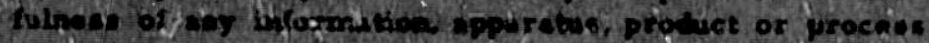

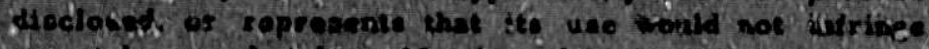

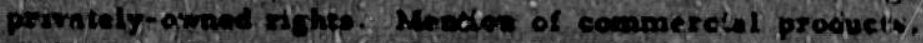

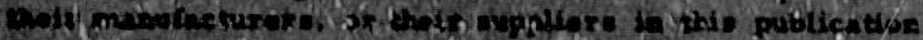

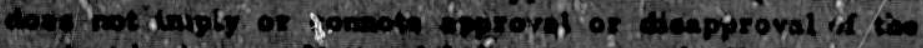

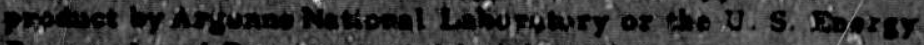

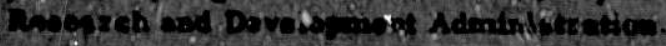

\section{2}
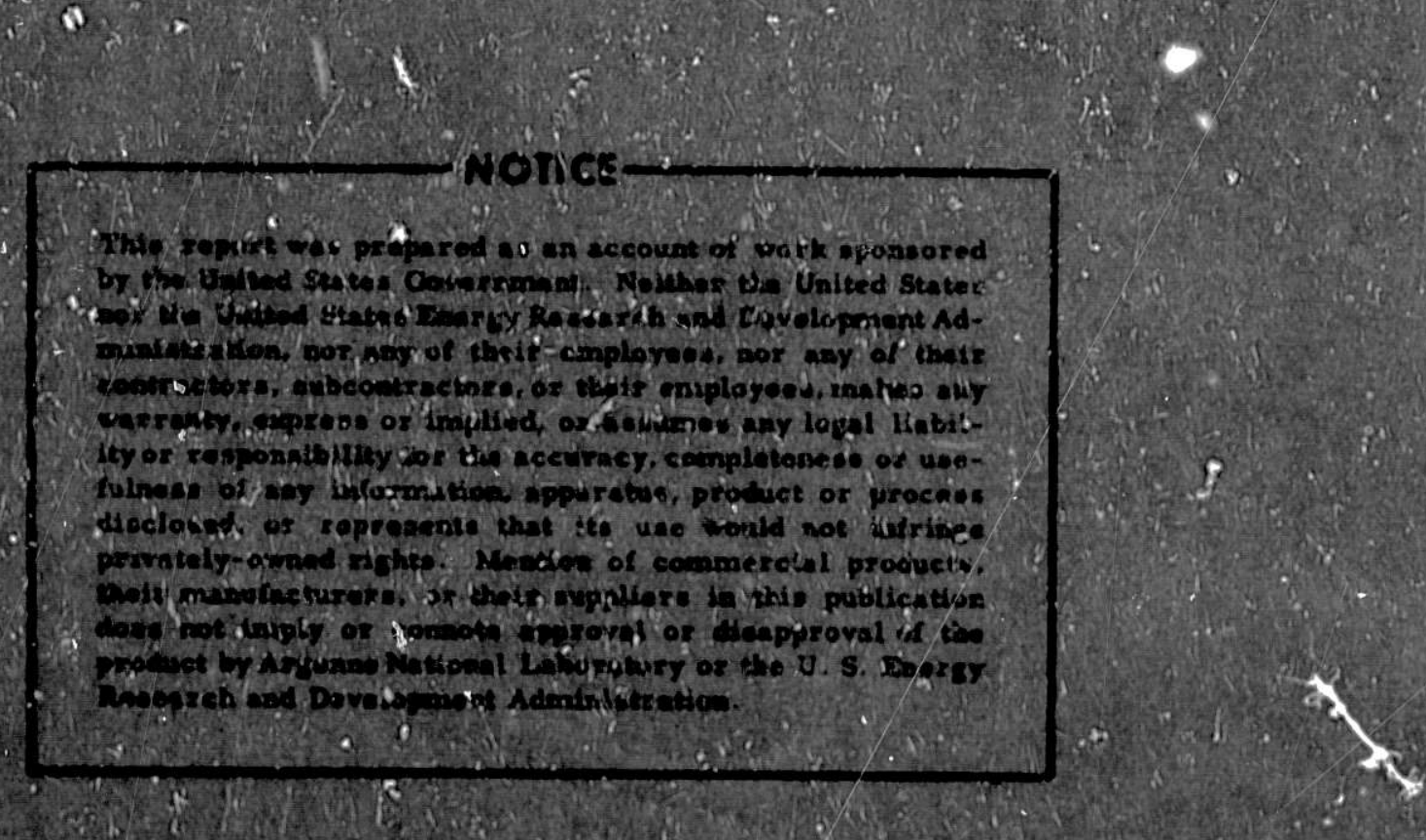
Distribution Category:

LMFBR Fuels and Materials

Engineering and Development (UC-7?b)

ANL-76-28

AR.GONNF. NATIONAL LABORATORY

9\%00 South Cass Avenue

Argonne, Jilinois 60439

U-Pu-Zr METAL ALLOY:

A POTENTIAL FUEL FOR LMFBR's

by

C. M. Walter, G. H. Golden, and $N$. J. Olson*

EBR-U Project

November 1975

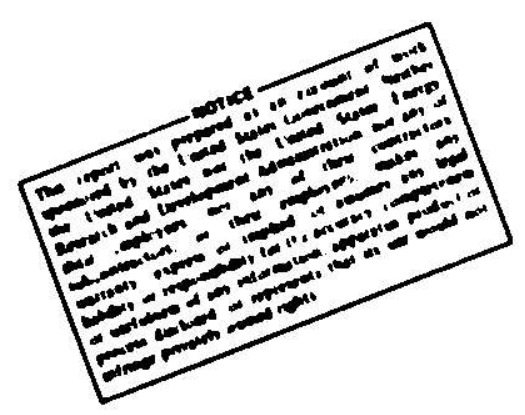

Now with Battelle Pacific Northwest Laboratory, Richland, Washir:gton 

TABLE OF CONTENTS

Page

ABSTRACT $\ldots \ldots \ldots \ldots \ldots$

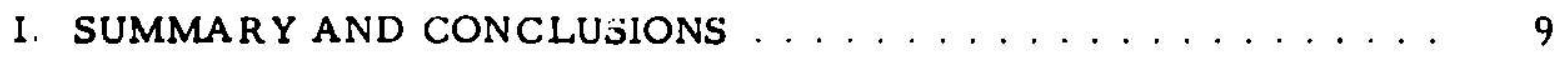

A. Potential Advantages . . . . . . . . . . 9

B. Major Uncertainties. . . . . . . . . . . . . . . 10

C. Recomnendations for Further Studies. . . . . . . . . . 11

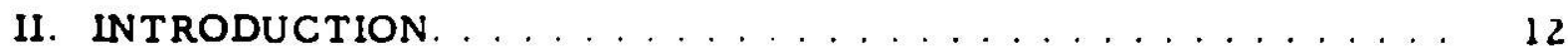

A. Scope and Objectives . . . . . . . . . . . . 12

B. Design Concepts . . . . . . . . . . . . . . . 13

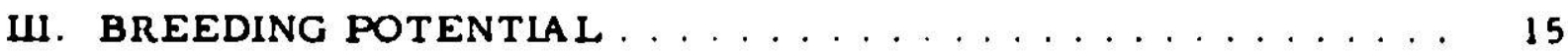

A. Comparison with Other Fuel Types............ is

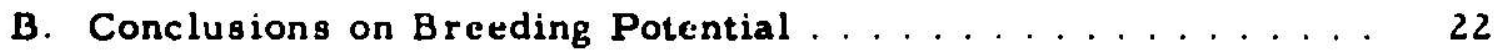

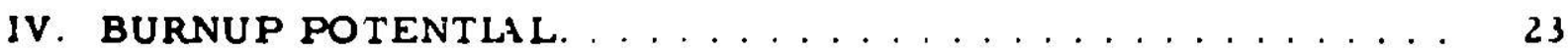

A. Irradiation Experience with U-5 wt \% Fs System (EBR-II

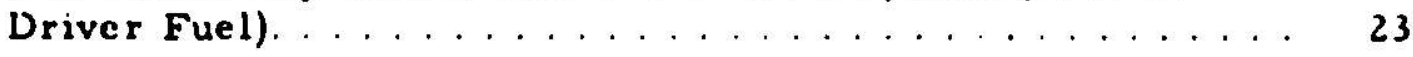

1. Statistical Analysis of Cladding Failures. . . . . . . 30

2. Cladding Fracture Modes . . . . . . . . . . . . . 32

3. Cladding-diameter Change $\ldots \ldots \ldots \ldots$

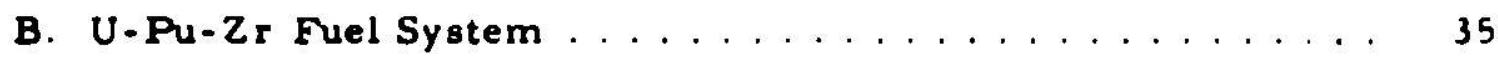

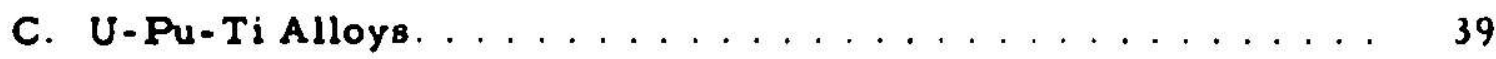

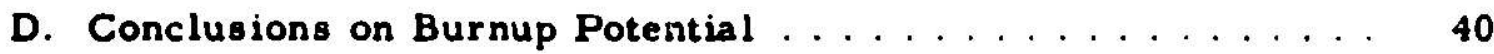

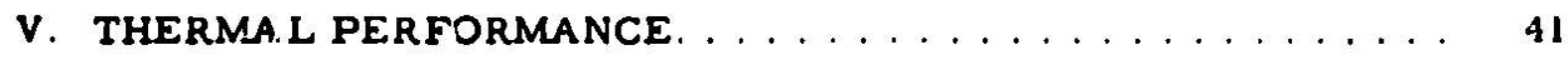

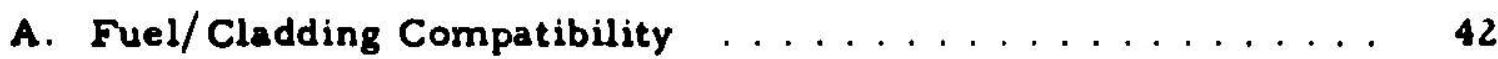

1. Fuel-Cladding Eutectic remperature . . . . . . . . 42

2. Solid-state Interdiffusion betweer - sel and Cladding . . . . 4 4t

3. Compatibility Variables . . . . . . . . . . . . . . 46

B. Fusl Meltin $\ldots \ldots \ldots \ldots \ldots \ldots \ldots$. . . . . . . . . . . .

C. Fuel Slumping. . . . . . . . . . . . . . . . . 49

D. Conclusions on Thermal Performance. . . . . . . . . . 5 51 
TABLE OF CONTENTS

$\underline{\text { Page }}$

VI. FUEL FABRICAGILITY. . . . . . . . . . . . . . 52

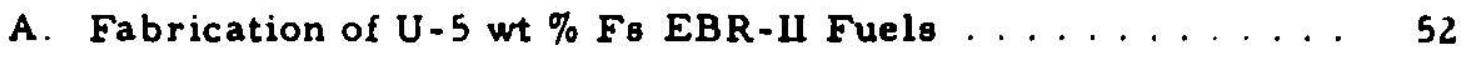

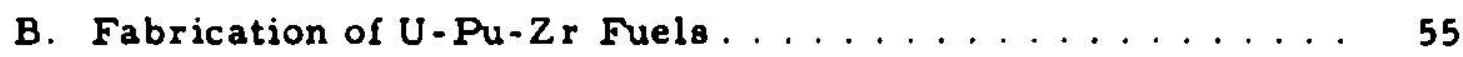

1. Preparation of Homogeneous Alloy Billets. . . . . . 55

2. Injection Casting. . . . . . . . . . . . . 56

3. Alternative Processes for Fuel-pin Fabrication....... 56

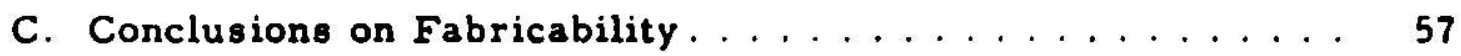

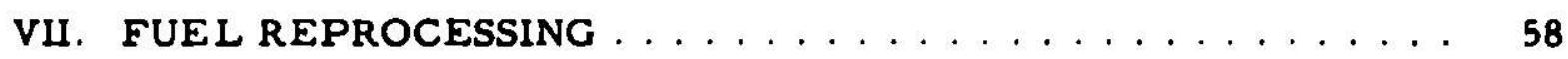

A. Reprocessing of U-5 wt \% Fs EBR-LI Driver Fuel . . . . . 58

B. Reprocessing of $U-P u-Z$ r Fuels. . . . . . . . . . 60

C. Conclusions on Reprocessing. . . . . . . . . . . . 64

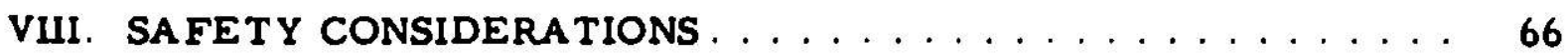

A. Safety-related Characteristics. . . . . . . . . . . 66

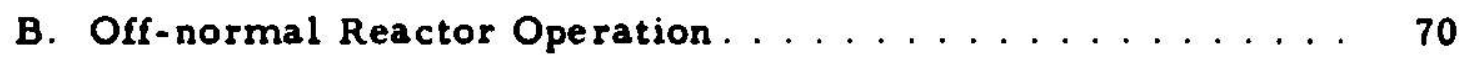

C. Conclusions on Safety Considerations . . . . . . . . . . 74

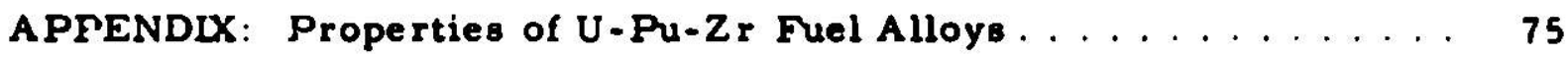

ACKNOW LEDGMENTS $\ldots \ldots \ldots \ldots \ldots$

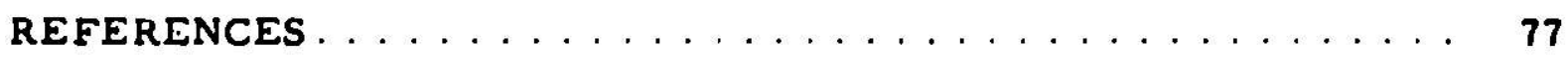




\section{LST OF FIGURES}

. Vo.

$\underline{\text { Title }}$

$\underline{\text { Page }}$

1. Effect of Swelling in Metallic Fuels on Release of Fission Gas.

2. Cumulative Failure Probability vs Maximum Eurnup for Variations in Design of Mark-1l Driver Fuel. . . . . . . . . . . . . . .

3. Typical Region of Cladding Fracture Surface of Element 230 from Subassembly X071A.

4. Attack of Claddirg Surface Adjacent to Fracture of Elen.ent 230 from Subassembly X071A. .

5. Maximum Diametral Cladding Strain-- Total and That Contributed by Swelling--for Mark-II Fuel Elements Irradiated in EBR-II . . .

6. Transverse Section of U-15 wt \% Pu-12 wt \% Zr Alloy Jacketed in Hastelloy-X, after 2.5 at. \% Burnup . . . . . . . . . . 36

7. Irradiation Zones and Diffusion Couples for U-Pu-Z.r System. . . 47

8. Solidus Lines for U-Pu-Zr Alloys 1-5 as a Function of Atomic Fractions of Zirconium and Plutonium . . . . . . . . . . . 48

9. Compressive Creep of U-18.5 wt \% Fu-14.1 wt \% Z r. . . . . . 50

10. Fabrication Scheme for Metallic Fuel .............. 53

11. Fission-product Removal in Melt Refining of EBR-II U-Fs Fuel. . 59

12. EBR-1I Lic, id-metal Process for Reclamation of Melt-refining Skulls. . . . . . . . . . . . . . . . . . . . . 61

13. Principal Steps in a Possible Pyrochemical Process for $\mathrm{U}-\mathrm{Pu}-\mathrm{Ti}$ Core and Uranium Blanket 


\section{LIST OF TABLES}

No.

$\underline{\text { Title }}$

Page

1. Densities of Mixed-oxide. Mixed-carbide, Mixed-nitride. and U-Pu-10 wt \% Zr Fuels . . . . . . . . . . . . . . . . . .

II. Design Paramecers for Oxide-. Carbide-, and Nitride-fueled LMFBR's with a Rating of alinut $500 \mathrm{MWe}$

III. Design Parameters for Oxide-, Carbide-, and Metal-fueled LMFBR's with a Rating of about $1000 \mathrm{MWe} \ldots \ldots . . . . . .$. .

IV. Parameter Study of Single-zone Cores: Oxide Fuel with Fullpower Lifetime of 1.75 Years at $100,000-\mathrm{MWd} / \mathrm{T}$ on Burnup . . . .

V. Parameter Study of Single-zone Cores: Carbide Fuel with Fullpower Lifetime of 1.75 Y (.ars at 100,000-MWd/Ton Burnup....

VI. Parameter Study of Single-zone Cores: Carbide Fuel with Fullpower Lifetime of 2.50 Years at $100,000-\mathrm{MWd} /$ Ton Burnup . . . .

VII. Parameter Study of Single-zone Cores: Metal Fuel with Fullpower Lifetime of 1.75 Years at $90,000-\mathrm{MWd} /$ Ton Burnup. . . . .

VIII Comparison of Mark-LA and -II Fuel-element Designs Irradiated in EBR-II . . . . . . . . . . . . . . . . . . . . . . . . .

IX. Cladiing Failures of Encapsulated Experimental Mark-II Elements with SA $304 \mathrm{~L}$ Cladding: 93\%-enriched \&uel, 24-in.-long Elements

X. Cladding Failures of Encapsulated Experimental Mark-LI Elements with SA $304 \mathrm{~L}$ Cladding: 93\%-enriched Fuel, 26-in--long Elements

XI. Cladding Failures of Encapsulated Experimental Mark-II Elements with SA $304 \mathrm{~L}$ Cladding: 80\%-cnriched Fuel, 24-in.-long

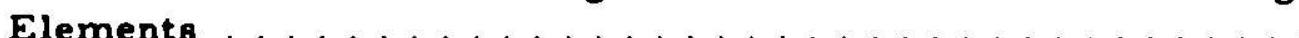

XII. Failure Data Used in Analysis of 80\%-enriched, 24-in.-long Encapsulated Experimental Mark-II Elements wilh SA 304L Cladding .

XIII. Cladding Failures of Encapsulated Experimental Mark-II Elements with SA $304 \mathrm{~L}$ Cladding: 80\%-enriched Fuel, 26-in.-long

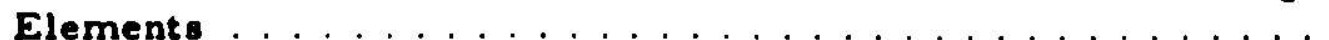

XIV. Failure Data Used in Analysis of 80\%-enriched, 26 -in--long Encapsulated Experimental Mark-II Elements with SA $304 \mathrm{~L}$ Cladding . . . . . . . . . . . . . . . . . .

XV. Status of 64\%-entiched, 26-in.-Iong Encapsulated Experimental Mark-U Elements with SA $304 \mathrm{~L}$ Cladding .............. 


\section{LST OF TABLES}

No.

$\underline{\text { Title }}$

Page

XVI. Status of 64\%-enriched, 26-in.-long Encapsulated Experimental Mark-II Elements with SA 316 Cladding .

XVII. Failure Statistics of 64\%-enriched, 26-in.-long Unercapsulated (X180) Experimental Mark-II Elements with SA 316 Cladding . . . . . . . . . . . . . . . . . . 30

XVIIl. Design and Operating Palameters for U-Pu-Zr and U-Pu-Ti Fuel Irradiated in EBR-II . . . . . . . . . . . . 38

XIX. Fuel-Cladding Eutectic Temperatures ............4 43

XX. Composition of Advarsed Cladding Alloys. . . . . . . . . . 44

XXI. Out-of-pile Solid-state Penetrations of Fuels into Stainless Steel Cladding in One Year................ 45

XXII. Comparison of In-reactor and Out-of-reactor Penetrations of Stainless Steel Cladding at $1200^{\circ} \mathrm{F} \ldots \ldots \ldots$

XXIH. Mean and (Range of) Atomic Percentages of Plutonium, Zirconium, and Uranium in Irradiation Zones of Alloys 4 and 5 after 4.5 at. $\%$ Burnup. . . . . . . . . . . . . . 47

XXIV. Melting Points of Metallic Fuels . . . . . . . . . . . . 49

XXV. EBR-U U-5 wt \% Fs Fuel Elements Produced as of June 1975. 54

XXVI. Chemical Analysis of Chill-cast U-Pu-Zr Alloys ....... 55

XXVII. Safety-related Characteristics of Large Metal- and Oxidefuelod LMFBR's........................ 66

XXVIII. Physical Properties of U-Pu-Zr Alloys . . . . . . . . . 75

XXIX. Tensile Properties of Extruded U-15 wt \% Pu-10 wt \% Zr . . 75 



\author{
U-PU-Zr METAL ALLOY: \\ A POTENTIAL L, FUEL FOR LMFBR's \\ by \\ C. M. Walter, G. H. Golden, and N. J. Olson
}

\begin{abstract}
AISTRACT
This report critically reviews the available information pertinent to the potential use of U-Pu-Z,r alloy fuels clad with stainless stecl in LMFBR's. The areas considered include breeding potential, burnup potential, therma! performance. fuel fabricability, fuel reprocessing, and safety consideratio.ns. "4.cause information on U-Pu- $Z_{r}$ alloys is limited, wide use is $\therefore$ ide of experience with EBR-II metallic driver fuel to infer a' $v$ ntages and limitations of $U-P u-Z r$ fuels. It is concluded is sufficient potential exists for the applicability of U-Pu-Z r fuels to LMFBR's to warrant additional analytical and experimental studies.
\end{abstract}

\title{
1. SUMMARY AND CONCLUSIONS
}

The principal advantages, uncertainties, and recommendations for the U-Pu-Zr metallic fuel system are summarized below.

\section{A. Potential Advantages}

1. The piricipal advantage of U-Pu-Zr fuels is their potantial for hign brecding ratio due to their high fertile/fissile atom densitics. Earlier studies showed that U-Pu- 10 wt \% $\mathrm{Zr}$ has similar or perhaps slightly higher breeding ratios than (U. Pu)C fuels.

2. U-Pu-Zr fuels clad with stainless steel have a potential for high burnup (in excess of 10 at. \%) at peak cladding temperatures of $1200-1300^{\circ} \mathrm{F}$. Although U-Pu-Zr fuels clad in Type 316 stainless steel have been irradiated only to 4.5 at. \% burnup, metallic EBR-Il driver fuel (U-5 wt \% FB, clad with stainles 8 steel that has a number of similarities in behavior) has shown high reliability up to 10.5 at. \% burnup.

3. U-Pu-Zr fuels clad with stainless steel have the potential for fairly high-temperature operation by virtue of their high fuel-cladding eutectic temperatures $\left(-1500^{\circ} \mathrm{F}\right)$ and high solidus temperatures $\left(-i j 00^{\circ} \mathrm{F}\right)$. Low fuel-cladding eutectic temperatures and low solidus temperatures for metallic fuels containing plutonium have previously been a major limitation. 
4. It appears that the fuel-fabrication processes (based on injection casting) used to fabricate over 100,000 irradiated and unirradiated EBR-II driver-fuel elements can be extended without significant difficulty to the fabrication of irradiated and unirradiated $U-P u-Z r$ fuel elements. Small numbers of U-Pu-Zr fuel elements have been successfully made by these processes.

5. Although a direct extension of the simple melt-refining reprocessing aycle used for EBR- $\amalg$ driver fuel is not possible for U-Pu-Zr alloys, direct application of segments of that cycle is fcasible. Specifically, melting of the ir radiated fuel to remcre gaseous and volatile fission products can be applied to U-Pu-Zr. Much of the EBR-II experience with a close-coupled reprocessing facility that returns fuel to the reactor within 45 days of discharge from the reactor is applicable. The mell-refining process has the additional advantage that it can be conveniently scaled to fit reactor size, in contrast to the aqueous process.

6. Metallic fuels have potertial advantages over oxide fuel for runbeyond-claciding-breach operation. These acivantages primarily result from their better compatibility with the sodium coolant.

7. Scoping calculations indicate that, in LMFBR's of equivalent size, the inher:nt prompt negative feedback for $U-P_{L}-Z_{1}$ fuel is similar to that for oxide fuel.

B. Major Uncertaintir:s

1. Because calc':lations of breeding ratio, inherent prompt negative feedback. and reactor response under off-normal conditions are very dependent on the details of a specilic reactor design, the calculations performed to date should be considered tentative.

2. The irradiation performance at high burnups (>4.5 at. $\%$ ) of U-Pu-Zr fuels clad with stainless steel has not been experimentally determined. Although the irradiation behavior of $\mathrm{U}-\mathrm{Pu}-\mathrm{Z}_{\mathrm{r}}$ fuels is $\mathrm{similar}$ to that of U-5 wt \% FB EBR-II driver fuel in many respects, the re are important differences. the effects of which are unknown at high burnup.

3. The high fuel-cladding eutectic temperatures and the high fuel/ cladding compatibility found in the U-Pu-Zr/atainless oteel syotem are anomalous when compared to other plistonium-containing metallic fuels. Reliance on this high eutectic temperature and fuel/cladding compatibilaty must be accompanied by a good understanding of their cauce. Although oxygen levels in the fuel and/or cladding appear to be associaled with the high eutectic temperature, a fundamental understanding of the cause of this high eutectic temperature, both in and out of the reactor. is not avallable from atudies conducted to date. 
4. Although the basic injection-casting fuel-fabrication process has been adequately demonstrated for production of U-5 wt \% Fs EBR-II driver fuel, it has only been used to produce small experimertal quantities of U-Pu-Zr fuel elements.

5. Complete schemes for reprocessing of irradiated U-Pu-Zr alloys ha; e been proposed. Significant portions of these schemes have been tested on EBR-II U-5 wt \% Fs driver fuels and are applicable to U-Pu-Zr alloys, but major portions of the schemes are as yet untested on high-burnup metallic fuels.

C. Recommendations for Further Studies

1. Detailed calculations of breeding ratios, doubling times, and safety-ielated aspects of U-Pu-ZZr-fueled LMFBR systems are required to provide the assurance that such systems have adequate potential to justify further development. These calculations are also required to provide guidance on fuel-element design and operating conditions for experimental irradiations.

2. The irradiation of experimental fuel elements (specifically, U-15 wt \% Pu-10 wt \% Zr clad with cold-worked Type 316 stainiess steel and advanced alloys) to high burnup is required to deternine the reliability of this fue! system as well as to characterize its irradiation behavior.

3. The cause of the high eutectic temperature and high fuel/cladding compatibility in the $\mathrm{U}-\mathrm{Pu}-\mathrm{Zr} / \mathrm{stainless}$ steel system requires additional experimental as well as analytical effort, using irradiated and unirradiated alloys. For irradiated materials, careful pre-and postirradiation cnaracterization and analysis of experimental fuel-element irradiations (see preceding paragraph) should be adequate. However, the fundamental understanding of the cause will require futstantial out-oi-reactor effort, particularly on determining the possible role played by oxygen.

4. Additional effort is required to optimize fabrication of $(\mathrm{r}-\mathrm{Pu}-\mathrm{Zr}$ fuel pins. Of particular importance is work on the preparation of homogeneous alloys and on the development of the injection-casting process.

5. Development and demonstration are required for the proposed fast-turnaround fuel-reprocessing steps to convert, in a close-coupled fuclrecycle facility, ir radiated $U-P u-Z r$ into new fuel elements for reiriadiation. 


\section{INTRODUC'IION}

\section{A. Scope and Objectives}

This report objeciively summarizes and evaluates the current state of knowledge on $\mathrm{U}-\mathrm{Pu}-\mathrm{Zr}$ fuel alloys that is germane to their potential use in LMFBR's. We will examine the major advantages and disadvantages of U-Pu-Zr fuels and identify principal areas of uncertainty in their behavior. Recommendations will be made on the value of additional studies for these alloys, as well as on specific areas which require further study if $\mathrm{U}-\mathrm{Pu}-\mathrm{Zr}$ fiels are to be pursued.

fuels:

The following topics will be considered in the evaluation of $U-P u-Z r$

1. Putential for breeding.

2. Iiradiation performance in fast reactors.

3. Thermal performance, with emphasis on fuel/cladding compatibility.

4. Fuel fabricability.

5. Fuel reprocessing.

6. Safety-related considerations.

This report primarily considers ternary U-Pu-Zr alloys in the composition range of $12-18$ wt \% Pu and 6-14 wt \% $\mathrm{Zr}$ : however, the emphasis is placed on U-15 wt \% Pu- 10 wt \% Zr as a reference. Cladding materials include Types 304 and 316 stainiess steel and a number of advanced alloys high in nickel, chromium, and, in some cases, cobalt; but the emphasis is on Type 316 stainless steel as a reference. Uranium-15 wt \% Pu- 10 wt \% Zr and Type 316 stainless steel were chosen as reference materials because of the relative amount of data and analyses avallable on them, and because they represent a fuel system that could probably be sufficiently developed in the minimum time.

Although this report 28 noi intended to provide an exhaustive review of all data a vailable on alloy fuels (the data for plutonium-bearing alloys were well summarized by Kittel et al. ${ }^{\prime}$ in 1971 ), information on other alloy fuels will be introduced where appropriate. Of particular value is the experience with U-5 wt \% Fs.* Uranium-5 wt \% fissium clad with Types $304 \mathrm{~L}$ and 316 stainless steel has been used as the exclusive driver fuel in the EBR-II reactor for more than 10 years. The information gained with $\mathrm{U}-5$ wt $\% \mathrm{Fs}$ in EBR-U the refore constitutes the largest single body of experience avaulable

-Fisslum $(F)$ is an equilibilum c ncentration of fission-product elemeno le ft by the pyrometallurgical reprocessIng cycle designed for ERR-II and consists of 2.4 wi molybdenum. 1.9 wt w ruthenium. 0.3 wt \% thodium. 0.2 wt \% palladlum. 0.1 wt $\%$ zirconium, and 0.01 wt $\%$ niobium. 
on the application of metallic fuels to fast reactors. Furthermore, there are a number of similarities between $U-F s$ and $U-P u-Z r$ fabricability, reprocessing, safety properties, and irradiation behavior. Because of these two factors, it is appropriate to inclucie somewhat detailed information on U-Fs in this report.

\section{B. Design Concepts}

Early engineering development of metal fucls for EBR-II centered on attempting to contain the fuel swelling with a strong cladding materiali alternatively, a fuel-alloy developme: it prograrn was dirccted toward minimizing the fuel swelling. It was found that selective alloy additions greatly reduced swelling with respect to pure uranium, but a relative optimum was reached with the U-5 wt \% Fs alloy currently used as the driver fuel in EBR-II. The initial fuel swelling due to the accumulation of solid fission products could not be readily restrained, and some room for this initial swelling was incorporated into a design to reliably achicve moderate burnups. This concept led to the Mark-IA design, currently used only in the EBR-II coricol and safety rods, which allows for $17 \%$ fuel swelling before fuel/cladding co: ${ }^{2}$ act, accompanied by fission-gas releases from fuel to plenum of $\leq 2 \%$ of tctal invento:y. Even with such low gas release, the life expectancy of the design is burnup-limited due to (1) a small plenum volume of ahout 0.012 in. ${ }^{3}$ at 3 at. $\% \mathrm{BU}_{\text {max }}$ (maximum fuel-pin burnup) at normal operating temperatures, and (2) a thin cladding-wall thickness of 0.009 in. The Mark-LA design is currently qualified at 1.8 at. \% BU $\max$ to obta in essentially a zero probability of failure. Efforts are underway to increase this burnup limit to a value nearer 3.0 at. \%. About 80,0 jD Mark-IA driver-fuel elements have been irradiated in F.BR-II, and considerable experimental effort has been expended to learn as much as possible about the cladding failure modes. ${ }^{2.3}$

Further research at Argonne on the relationship between fuel swelling and gas release led to the engineering development of the Mark-II design currently used as the EBR-II driver fuel. This design concept allows for $33 \%$ fuel owelling $\mathrm{F}:$ ior to fue!/cladding contact, the plenum is much larger than that of the Mark-IA to accommodate the increased gas release, and the cladding is thicker ( 0.012 in.). It has been experimentally verified that interconnection of porosity occurs just prior to the swelling value of $33 \%$ theorized by Barnes." If large gab releases can be achieved prior to fuel/cladding contact, the contact pressures are dramatically reduced, as expcrimentally evidenced by the observed magnitudes of riechanical strain at a given burnup for the Mark-IA and -II designs." Therefore, there is considerable improvement of burnup capability of the Mark- I design over the Mark-LA. All EBR-Ildriver-fuel designs have used sodium as a thermal bond between the fuel pin and cladding. Therefore, changing the smear densities has been straightforward (i.e.. changing the pin diameter, the fuel enrichment, and, correspondingly, the wize of the sodium annulus between the pin and jacket).

To optimize performance of the metal fuel, a compromise between gas release and smear density (i.e., a large gas release requires a low smear density) is required. For the $33 \%$ fuel swelling that must be allowed to ensure 
large gas release, the smear density must be $75 \%$. Because of the sodium pin-to-cladding thermal bond, the smear density can be easily changed without significant effects on fuel or cladding temperatures. With the large gas releases, the plenum volume used is also a major design consideration. The Mar:k- $\amalg$ design concept thus far has shown a burnup capability of up to 10.5 at. $\%$ in EBR-11, ${ }^{6}$ even though the design parameters such as choice of cladding (Type $304 \mathrm{~L}$ stáinless steel) and plenum-volume/fuel-volume ratio ( $0.8-1.0)$ may not be optimum for future fast-reactor application.

Since fission-gas releasc and fuel swelling are major variables in the design of a metal fuel element, $\because$ is instructive at this point to consider them in more detail. Fuel swelling as a function of burnup and operating temperature varies widely, even for fuel from the same batch. ${ }^{7}$ However, it has been shown that fission-gas release is a function of fuel swelling. At fuel temperatures above $950^{\circ} \mathrm{F}$ (see Fig. 1), the initial gas release rises sharply from $\sim 2$ to $\sim 60 \%$ because of the interconnection of porosity, and is independent of the particular fuel-alloy composition. ${ }^{8,9}$ Therefore, the experimentally determined fuel swelling required for interconnection of the porosity (25-30\%) is between that allowed by the Mark-IA and the Mark-II designs. This is an important point to consider with respect to smear density. It is also important to note that the relationship between gas release and fuel swelling is nearly the same for all metal fuels; i.e., the gas release is large when interconnection of pnrosity occurs. Therefore, the optimum fuel-element designs are similar, for example, for both the U-5 wt \% metal EBR-I driver fuel and the more advanced $\mathrm{U}-\mathrm{Pu}-\mathrm{Zr}_{\mathrm{r}}$ alloy.

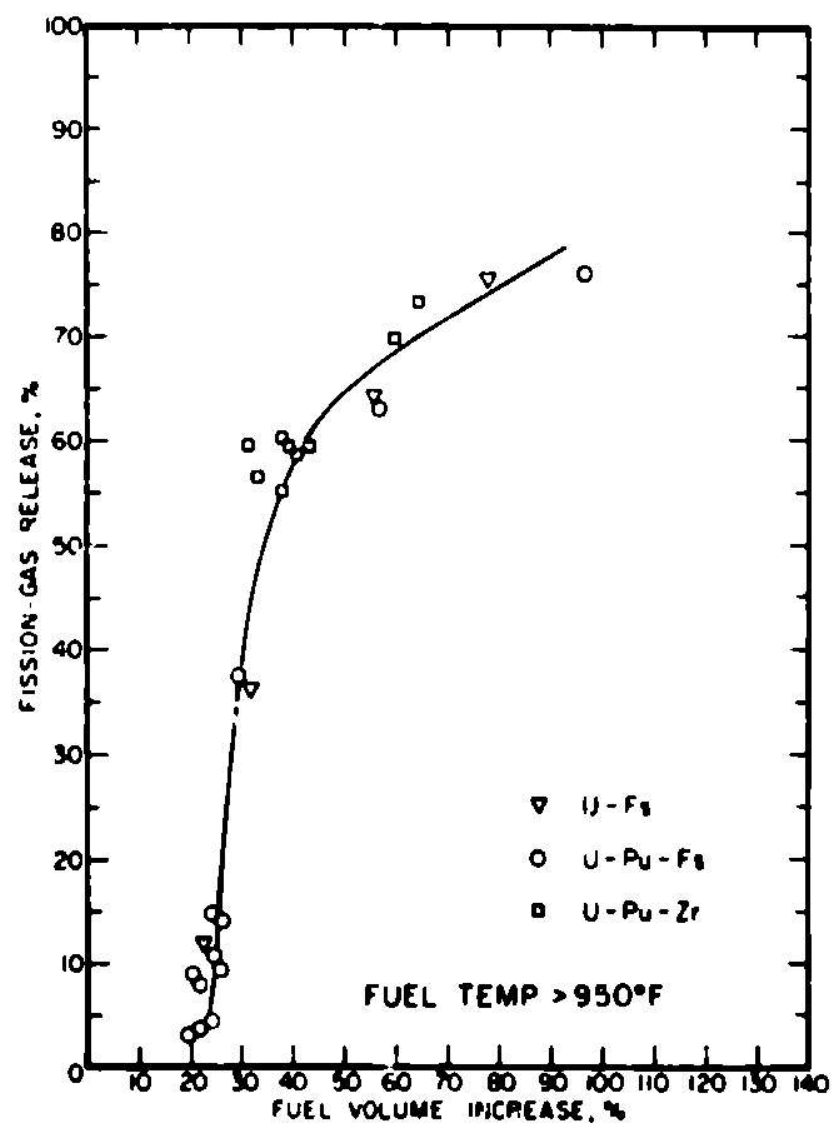

Fig. 1

Effect of Swelling In Metallic Fuets on Release of Fision Gas. ${ }^{8}$ ANL Neg. No. 106-9681. 


\section{I1I. BREEDING PO'TENTIAL}

\section{A. Comparison with Other Fuel Types}

The breeding ratio of a fast reactor is approximately proportional to the ratio of its ${ }^{238} \mathrm{U}$ atom density to its ${ }^{239} \mathrm{Pu}$ atcm density. That is, the more ${ }^{238} \mathrm{U}$ the reactor contains relative to its ${ }^{239} \mathrm{Pu}$ content, the better it will breed. The ${ }^{239} \mathrm{Pu}$ c -itical mass of a large power LMFBR of a given height and diameter is only weakly dependent upon the detailed composition of the reactor. For any fuel used in such a reactor, a given amount must be ${ }^{239} \mathrm{Pu}$; the remainder is ${ }^{238} \mathrm{U}$ and oxygen, carbon, or metal diluent, depending upon the fuel type. It thus follows that the greater the fuel density, the more ${ }^{2 s} U$ the reactor will conta $m$, and the better its breeding potential will be.

Table I shows theoretical densities and theoretical heavy-atom (HA) densities for mixed-oxide, mixed-carbide, mixed-nitride, and $U-P u-10$ wt $\% \mathrm{Zr}$ metal-alloy fuels. On the basis of HA density, the metal fuel has the greatest breeding potential of the four fuel types.

IABLF: 1. Densites of MLxed-oxide, Mixed-carbide. $M i x \cdot d-n i t r i d \cdot$, and $U-P u-10 \mathrm{we} \% \mathrm{Zr}$ Fuess

\begin{tabular}{|c|c|c|c|c|}
\hline & $\begin{array}{l}\text { Mixed } \\
\text { Oxideto }\end{array}$ & $\begin{array}{c}\text { Mixed } \\
\text { Carbide10 }\end{array}$ & $\begin{array}{l}\text { Mixed } \\
\text { Netrideto }\end{array}$ & $\begin{array}{l}L^{\prime}-P_{u}-10 \\
\text { we } \% \angle r^{\prime \prime}\end{array}$ \\
\hline Theoretacal fuel density. $\mathrm{cm}^{\prime}$ & 10.4 & 13.0 & 143 & 16.0 \\
\hline Theorctucal HA density. $\mathrm{c}^{\mathrm{c}} \mathrm{cm}^{\prime}$ & 9.8 & 12.4 & 13.5 & 14.4 \\
\hline
\end{tabular}

Many studies have been made to calculate breeding ratios for LMI'BR's using different fuels. Most such studies have been for mixed-oxide fuel, some have been for mixed-carbide fuel, and a few have been for mixed-nitride and metal-alloy fucls. Unfortunately, it is difficult to use the se studies to make consistent comparisons of the breeding potential of the various fuel types. This is due to differences in design assumptions such as:

1. Core H/D (ratio of height to diameter) as based upon consideration of sodium-void effect versus conomic optimization.

2. Core volume.

3. Thermal power level and spatial distribution (radial zoning).

4. Blanket size and composition.

5. Smeared fuel density.

6. Peak allowabie linear power.

7. Peak allowable turnup.

8. Refueling uchers:. 
Other differences are in the cross-section sets used for physics analyses, in the physical, chemical, and mechanical properties, etc.

With such differences, it is not surprising that rather wide ranges of breeding ratios have been reported for the different fuel types. These ranges are about 1.15-1.35 for mixed-oxide fuel and 1.30-1.50 for mixed-carbide, mixed-nitride, and metal fuels. Thus, comparisons of various fuel types are meaningful only to the extent that there is consistency of design paranieters for the reactors using the se fuel types.

A recent design study by Caspersson et al ${ }^{10}$ gives breeding ratios for mixed-oxide-, mixed-carbide-, and mixed-nitride-fueled LMFBR's sized to deliver about $500 \mathrm{MWe}$. The driver-region height was set at $3 \mathrm{ft}$ for all three reactors; other design parameters are shown in Table II. The reactor breeding ratios for the oxide, carbide, and nitride LMFBR's are 1.20,1.42, and 1.35 , respectively. Note that these cores have volumes of about 2400 3100 liters, fuel volume fractions of $33.3-36.0 \%$, and aspect ratios (H/D's) of $0.44-0.50$.

\begin{tabular}{|c|c|c|c|}
\hline & $\begin{array}{l}\text { Mixudd } \\
\text { Oxide. }\end{array}$ & $\begin{array}{l}\text { Mreced } \\
\text { Ciertiule }\end{array}$ & $\begin{array}{l}\text { Mixed } \\
\text { Nitride. }\end{array}$ \\
\hline Fuel turm & $\left(1 \cdot \mathbf{P}_{u}\right) U_{1}$ +o & (L. Julc, ut & $11 . P_{11} N_{1}$ no \\
\hline Fuel bund malerial & Holsum & Sindum & Sorlusul \\
\hline \multicolumn{4}{|l|}{ Healy-melal aniedr denndllen } \\
\hline \& $" m !$ & iov & $10: 8$ & $11: 4$ \\
\hline "ut U.eurettad & 800 & 341 & n: : \\
\hline Cludding OD ID & $0: 500: 20$ & 0 shit o sit & 013100301 \\
\hline Core-regton heavy metal cunteme kg & 7837 & $4+40$ & $16: 4$ \\
\hline Averake linest power. $h W$ lt & N $\mathbf{b}$ & IE 6 & In 8 \\
\hline Average upesalic puwer kW kk!IM & $: 14$ & $11 \cdot$ & 114 \\
\hline Core-rekson equivalent OD. It & 674 & $0: 1$ & 100 \\
\hline Cur. $H \mathrm{D}^{4}$ & $0+t$ & $0+6$ & $u>0$ \\
\hline Cure volume. 1 & 1070 & $\therefore 540$ & $\therefore+0:$ \\
\hline Driver-furi volume Iraction. & \$1 1 & 150 & 160 \\
\hline Tolal cure pounr. MH & IOGH & $10 \times 0$ & $110:$ \\
\hline Averane power denetty. $k W$, & int & +21 & $|e|$ \\
\hline
\end{tabular}

acore height st lew oll thre.. reactors

An unpublished parametric study of 1000-MWe LMFBR's using mixedoxide, mixed-carbide, and metal-alloy (U-Pu-10 wt \% Zr) fuel wos done at Argonne National Laboratory in 1967. All such reactors had a power output of $2500 \mathrm{MWt}$, a core-power/reactor-powi.s ratio of 0.9 . average core power densities ranging parametrically from 300 to $700 \mathrm{~kW} /$ liter, and core apect rutios ranging parametrically from 0.2-1.0. Design parametera for the reactors considered are shown in Table $\Psi$. 


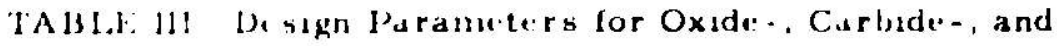

Melal-fuell c' LMFBK's with a Rathelg of about $1000 \mathrm{MW}$.

\begin{tabular}{|c|c|c|c|c|}
\hline & $\begin{array}{l}\text { Mixed } \\
\text { Oxide }\end{array}$ & $\begin{array}{c}\text { Mixed } \\
\text { Carbide- I }\end{array}$ & $\begin{array}{c}\text { Mixed } \\
\text { Cartide }-2\end{array}$ & $\begin{array}{l}U-P u-10 \\
w t \% \% r\end{array}$ \\
\hline Fuel burmup. MWd ton & 100,000 & 100.000 & 100.000 & 90.000 \\
\hline Full-power luel 11, 12111 yours & $17 \mathrm{~h}$ & 175 & $\therefore 50$ & 1.75 \\
\hline Sumedred tuel density. "ol throuretical & nO & no & BC & 70 \\
\hline Average lamear power. kW tl & $10+$ & 10 & 10 & b \\
\hline 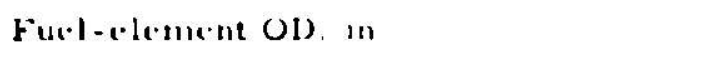 & 025.14 & $0: 71$ & 0318 & 0.212 \\
\hline Claddung-wall thekness. in & U OI & 0115 & 0.015 & 0015 \\
\hline
\end{tabular}

Two different sets of cases of the carbide fueied reactor were considered. In the first, the full-power lifetime of the fuel was taken as 1.75 years, the same as that used for all the reactors fueled with mixed oxides and $U-P u-10$ wt \% $Z$ r. For a given average core power density, burnup, and fractional fuel density, this led to unrealistically lower fuel volume fractions than were obtained for either the mixed-oxide or metal-alloy reactors. The lower fuel volume fractions resulted in correspondingly lower coolant velocities and core pressure drops and unrealistically low breeding ratios. It was thus decided to study another set of carbide-reactor cases in which flow characteristics were more like those of the mixed-oxide and metal-alloy reactors. This was done by increasing the full-power fuel lifetime to 2.5 years, leading to fuel volume fractions closer to those in the other systems. Results for the mixed-oxide fuel are given in Table IV. for the two mixed-carbide cases in Tables $V$ and VI, and for the metal-alloy fuel in Table VIl. The cores are all single-zone: i.e.. all fuel has the same enrichnent.

Interpolation of the results in Table $1 \mathrm{~V}$ indicates that. for a mixedoxide reactor having an $\mathrm{H} / \mathrm{D}$ of 0.44 and an average core power density of $350 \mathrm{~kW} /$ liter. the fuel volume fraction is $26.0 \%$ and the breeding ratio (BR) is 1.19. For a mixed-carbide core with the same full-power fuel lifetime of 1.75 years. an $H / D$ of 0.48 , and an average core power density of $\$ 2.0 \mathrm{~kW} /$ liter. the fuel volume fraction (sce Table $V$ ) is $23.5 \%$ and the breeding ratio is 1.32 . For the corresponding case with a full-power fuel lifetime of 250 years (Table VI). the ruel volume traction $2833.6 \%$ and the breeding ratio 281.48 .

The metal-alloy reactors considered in Table VII (1.75-yea: fullpower fuel lifetime) have hydraulic characteristic nearer to those of the 1.75-year carbide reactors than to those of the 2.50-year carbide reactors. That is, the netal reactor have conservatuvely low fuel volune fractions. and this has a strongly adverse effect on their breeding ratios. Nevertheless. the breeding ratio of a metal reactor having an 110 of 05 and an average core power denstly of $+20 \mathrm{~kW}$ / liter is 1.36 The corresponding fuel volume fraction is only $26.9 \%$. If the fucl volume fraction were increased to about $34 \%$. the brecding ratio would inc rease to about 1 . is 
TABLE IV Parameter Studv af Singie-zone Corcs: Oxide Fuel wath Full-power Lifetime of 17 ; Years at $100.000-\mathrm{MWd} /$ Ton Burnup

\begin{tabular}{|c|c|c|c|c|c|c|c|c|c|c|c|}
\hline \multirow[b]{2}{*}{ H. D } & \multirow{2}{*}{$\begin{array}{c}\text { Core } \\
\text { Power } \\
\text { Density. } \\
\text { kW ilater }\end{array}$} & \multirow{2}{*}{$\begin{array}{l}\text { Core } \\
\text { Volume. } \\
\text { laters }\end{array}$} & \multirow{2}{*}{$\begin{array}{c}\text { Core } \\
\text { Height. } \\
\text { cm }\end{array}$} & \multirow{2}{*}{$\begin{array}{c}\text { Core } \\
\text { Diameter. } \\
\text { cm }\end{array}$} & \multicolumn{3}{|c|}{ Core Volume Fractions $\%$} & \multirow{2}{*}{$\begin{array}{c}M_{\text {crit }} \\
\quad \text { kg }\end{array}$} & \multirow{2}{*}{$\left(\frac{P_{\max }}{P_{\text {avg }}}\right)_{a x}$} & \multirow{2}{*}{$\left(\frac{P_{\max }}{P_{\text {avg }}}\right)_{r a d}$} & \multirow[b]{2}{*}{ BR } \\
\hline & & & & & Fuel & Structure & Coolant & & & & \\
\hline \multirow[t]{2}{*}{1.0} & 300 & 7500 & 212.14 & 212.14 & 22.25 & 14.47 & 63.28 & 1878 & 1.3285 & 1.6423 & 1.157 \\
\hline & 400 & 5625 & 19263 & 192.63 & 29.66 & 18.14 & 52.20 & 1678 & 1.3393 & 1.6647 & 1.238 \\
\hline \multirow[t]{2}{*}{0.8} & 300 & 7500 & 18257 & $2<830$ & 22.25 & 13.87 & 63.88 & 1877 & 1.3014 & 1.6676 & 1.154 \\
\hline & 400 & 5625 & 165.81 & 207.57 & 29.66 & 17.30 & 53.04 & 1675 & 1.3129 & 1.6902 & 1.239 \\
\hline \multirow[t]{3}{*}{0.6} & 300 & 7500 & 150.88 & 251.46 & 22.25 & 13.30 & 64.45 & 1900 & 1.2658 & 1.7018 & 1.148 \\
\hline & 400 & 5625 & 136.86 & 228.30 & 29.66 & 16.50 & 53.84 & 1694 & 1. 2779 & 1.7239 & 1.240 \\
\hline & 500 & 4500 & 127.10 & 212.14 & 37.08 & 20.07 & $\$ 2.85$ & 1556 & 1. 2892 & 1.7485 & 1.307 \\
\hline \multirow[t]{3}{*}{0.4} & 300 & 7500 & 114.91 & 287.73 & 22.25 & 1269 & 65.06 & 1990 & 1.2140 & 1.7499 & 1.141 \\
\hline & 400 & 5625 & 104.55 & 261.51 & 29.66 & 15.67 & 54.67 & 1767 & 1.2276 & 1.7731 & 1.241 \\
\hline & 500 & 4500 & 96.93 & 242.62 & 3708 & 1890 & +1.02 & 1618 & 1.2394 & 1.7972 & 1.316 \\
\hline \multirow[t]{4}{*}{0.2} & 300 & 7500 & 72.54 & 362.71 & 22.25 & 11.93 & 65.82 & 2330 & 1.1331 & 1.8327 & 1.130 \\
\hline & 400 & 5625 & 65.84 & 329.49 & 29.66 & 1466 & 55.68 & 2052 & 1.1466 & 1.8576 & 1.248 \\
\hline & 500 & 4500 & 00.96 & 305.71 & 3708 & 17.48 & 45.44 & 1865 & 1. 1581 & 1.8829 & 1.337 \\
\hline & 600 & 3750 & 75.30 & 287.73 & 44.50 & 20.75 & 34.75 & 1727 & 1.1683 & 1.9060 & 1.408 \\
\hline
\end{tabular}


TABLE $v$ Parameter Study of Single-zone Cores Carbide Fuel with Full-power Lifetime of 175 Years at iv0.000-MWd Ton Eurnup

\begin{tabular}{|c|c|c|c|c|c|c|c|c|c|c|c|}
\hline \multirow[b]{2}{*}{ H/ D } & \multirow{2}{*}{$\begin{array}{l}\text { Core } \\
\text { Power } \\
\text { Density. } \\
\text { kW liter }\end{array}$} & \multirow{2}{*}{$\begin{array}{l}\text { Core } \\
\text { Volume. } \\
\text { liters }\end{array}$} & \multirow{2}{*}{$\begin{array}{c}\text { Core } \\
\text { Height. } \\
\text { cm }\end{array}$} & \multirow{2}{*}{$\begin{array}{c}\text { Cure } \\
\text { Drameler } \\
\text { cm }\end{array}$} & \multicolumn{3}{|c|}{ Corr Volume Fractions. $\%$} & \multirow{2}{*}{$\begin{array}{c}M_{\text {crit }} \\
\mathbf{k g}\end{array}$} & \multirow{2}{*}{$\left(\frac{P_{\max }}{P_{a v g}}\right)_{a x}$} & \multirow{2}{*}{$\left(\frac{P_{\max }}{P_{a v g}}\right)_{r a d}$} & \multirow[b]{2}{*}{$\mathrm{BK}$} \\
\hline & & & & & Fuel & Structure & Coolant & & & & \\
\hline \multirow[t]{2}{*}{1.0} & 300 & 7500 & 2122 & 2122 & 16.82 & 1204 & 7114 & 1808 & 1.317 & 1.016 & 1228 \\
\hline & 400 & 5625 & 192.8 & 1926 & $\therefore 2+2$ & 1341 & 03.07 & 1052 & 1.325 & 1.626 & 1.322 \\
\hline \multirow[t]{2}{*}{0.8} & 360 & 7500 & 1828 & $\therefore 285$ & 1682 & 1134 & 7184 & 1800 & 1284 & $1.0+0$ & 1.220 \\
\hline & 400 & 5625 & 166.1 & 2070 & $22+2$ & 13.53 & 6405 & 1053 & 1.298 & 1.653 & 1.310 \\
\hline \multirow[t]{3}{*}{0.6} & 300 & 7500 & 1509 & 2515 & 1682 & 108 & 7238 & 1892 & 1.253 & 1.674 & 1.208 \\
\hline & 400 & 5625 & 137.1 & 2285 & $22+2$ & 13.03 & 6455 & 1676 & 1.263 & 1.687 & 1.308 \\
\hline & 500 & 4500 & 127.3 & 2122 & 2803 & 15.29 & 56.68 & 1528 & 1.272 & 1.704 & 1.385 \\
\hline \multirow[t]{4}{*}{$0+$} & 300 & 7500 & 115.2 & 2879 & 16.82 & 1072 & 7240 & 1990 & 1.203 & 1724 & 1.186 \\
\hline & +00 & 5625 & .04 .6 & 261.6 & $22+2$ & 1236 & 6522 & 1750 & 1.213 & 1.736 & 1.300 \\
\hline & 500 & 4500 & 971 & 2429 & 2803 & 1452 & $57+5$ & 1598 & 1.223 & 1754 & 1.383 \\
\hline & 600 & 3700 & 914 & 228.5 & 33.54 & 17.54 & 4882 & 1485 & 1.233 & 1.775 & 1443 \\
\hline \multirow[t]{5}{*}{0.2} & 300 & 7500 & 72.6 & 362.8 & 16.82 & 926 & 73.93 & 2347 & 1.122 & 1.800 & 1.164 \\
\hline & 400 & 5625 & 65.9 & 329.6 & $22+2$ & 1123 & 66.35 & 2061 & 1.134 & 1.818 & 1.291 \\
\hline & 500 & 4500 & 61.2 & 306.0 & 2803 & 13.14 & 58.83 & 1863 & 1.144 & 1.837 & 1.390 \\
\hline & 600 & 3750 & 576 & 2879 & 3364 & 15.28 & 51.09 & $1 ? 17$ & 1.153 & 1.858 & 1.466 \\
\hline & 700 & 3214.3 & 54.7 & 273.5 & 3424 & 17.84 & 42.92 & 1605 & 1.162 & 1.878 & 1. 524 \\
\hline
\end{tabular}


TABLE VI. Parameter Study of Single-zone Cores. Carbide Fuel with Full-power Lifetime of 2.50 Years at 100.000-MWd, Ton Burnup

\begin{tabular}{|c|c|c|c|c|c|c|c|c|c|c|c|}
\hline \multirow[b]{2}{*}{ H/D } & \multirow{2}{*}{$\begin{array}{c}\text { Core } \\
\text { Power } \\
\text { Density. } \\
k W / \text { liter }\end{array}$} & \multirow{2}{*}{$\begin{array}{l}\text { Core } \\
\text { Voli:me. } \\
\text { liters }\end{array}$} & \multirow{2}{*}{$\begin{array}{l}\text { Core } \\
\text { Height. } \\
\text { cm }\end{array}$} & \multirow{2}{*}{$\begin{array}{c}\text { Core } \\
\text { Diameter } \\
\text { cm }\end{array}$} & \multicolumn{3}{|c|}{ Core Volume Fractions. $\%$} & \multirow{2}{*}{$\begin{array}{c}M_{\text {crit }} \\
\mathbf{k g}\end{array}$} & \multirow{2}{*}{$\left(\frac{P_{\text {max }}}{P_{\text {avg }}}\right)_{a x}$} & \multirow{2}{*}{$\left(\frac{P_{\text {raax }}}{P_{\text {avg }}}\right)_{\text {rad }}$} & \multirow[b]{2}{*}{ BR } \\
\hline & & & & & Fuel & Structure & Coolant & & & & \\
\hline 1.0 & 300 & 7500 & 212.2 & 212.2 & 24.03 & 12.80 & 63.18 & 2150 & 1.342 & 1.665 & 1.361 \\
\hline \multirow[t]{2}{*}{08} & 300 & 7500 & 182.8 & 2.3 .5 & 24.03 & 12.01 & 63.97 & 2147 & 1.316 & 1.689 & 1.361 \\
\hline & 400 & 5625 & 166.1 & 207.6 & 3203 & 15.12 & 52.84 & 1922 & 1.327 & 1.712 & 1.456 \\
\hline \multirow[t]{2}{*}{0.6} & 300 & 7500 & 150.9 & 251.5 & 24.03 & $11+1$ & 64.56 & 2171 & 1.281 & 1.723 & 1.358 \\
\hline & 400 & 5625 & 137.1 & 228.5 & 3203 & 14.27 & 53.69 & 1941 & 1294 & 1.746 & 1.460 \\
\hline \multirow[t]{3}{*}{0} & 300 & 7500 & 115.2 & 2879 & 24.03 & 10.57 & $65+1$ & 2262 & 1.231 & $1.76^{\circ}$ & 1.357 \\
\hline & 400 & 5625 & 104.6 & 261.6 & 3203 & 13.38 & 54.59 & 2017 & 1.245 & 1.794 & 1.465 \\
\hline & 500 & $\$ 500$ & 471 & 242.9 & 40.04 & 1657 & +339 & 1852 & 1.257 & 1.819 & 1.542 \\
\hline \multirow[t]{4}{*}{0.2} & 300 & 7500 & 72.6 & 3626 & 2403 & $9.4 i$ & 66.08 & $\angle 624$ & 1.151 & 1.851 & 1.351 \\
\hline & 400 & $56<5$ & 65.9 & 3290 & 32.03 & 1226 & 55.71 & 2310 & 1.165 & 1.876 & 1474 \\
\hline & 500 & 4500 & 612 & 3060 & 40.04 & 14.86 & 45.10 & 2107 & 1177 & 1.901 & 1.571 \\
\hline & 600 & 3750 & 57.6 & 2879 & 48.05 & 1822 & 33.73 & 1458 & 1.188 & 1.927 & 1.634 \\
\hline
\end{tabular}


TABLE vil. Paramete: Study of Single-zone Cores Metal Fuel with Full-power Lifetime of 1.75 Years at 90.000-MWd. Ton Burnup

\begin{tabular}{|c|c|c|c|c|c|c|c|c|c|c|c|}
\hline \multirow[b]{2}{*}{ H/D } & \multirow{2}{*}{$\begin{array}{l}\text { Core } \\
\text { Power } \\
\text { Density. } \\
k W / \text { liter }\end{array}$} & \multirow{2}{*}{$\begin{array}{l}\text { Core } \\
\text { Volume. } \\
\text { liters }\end{array}$} & \multirow{2}{*}{$\begin{array}{l}\text { Core } \\
\text { Height. } \\
\mathrm{cm}\end{array}$} & \multirow{2}{*}{$\begin{array}{c}\text { Core } \\
\text { Dumeter. } \\
\text { cm }\end{array}$} & \multicolumn{3}{|c|}{ Corc Volume Fractions. $\%$} & \multirow{2}{*}{$\underset{\mathrm{kg}}{\mathbf{M}_{\mathrm{crst}}}$} & \multirow{2}{*}{$\left(\frac{P_{\text {max }}}{P_{\text {avg }}}\right)_{a x}$} & \multirow{2}{*}{$\left(\frac{P_{\max }}{P_{\text {avg }}}\right)_{\text {rad }}$} & \multirow[b]{2}{*}{ BR } \\
\hline & & & & & Fuel & Structure & Coulant & & & & \\
\hline 1.0 & 300 & 7500 & 2122 & 212.2 & 1920 & 16.07 & 6473 & 1926 & 1321 & 1616 & 1257 \\
\hline \multirow[t]{2}{*}{0.8} & 300 & 7500 & 1828 & 228.5 & 19.20 & 15.67 & 65.13 & 1928 & 1.294 & 1642 & 1248 \\
\hline & 400 & 5625 & 166.1 & 2076 & 2560 & 18.81 & 5559 & 1080 & 1.301 & 1.652 & 1355 \\
\hline \multirow[t]{2}{*}{0.6} & 300 & 7500 & 1509 & 251.5 & $19<0$ & 14.93 & 0580 & 1955 & 1.259 & 1.075 & 1237 \\
\hline & 400 & 5625 & 137.1 & 228.5 & 25.60 & 17.95 & 56.45 & 1708 & 1.266 & 1.686 & 1.350 \\
\hline \multirow[t]{3}{*}{04} & 300 & 7500 & 115.2 & 287.4 & 19.20 & 13.96 & 6683 & 2050 & 1.209 & 1.722 & 1.221 \\
\hline & 400 & .625 & 1046 & 261.6 & 25.60 & 17.12 & 57.28 & 1790 & 1.218 & 1.736 & 1.339 \\
\hline & 500 & 4500 & 971 & 2429 & 32.00 & 20.45 & 47.55 & 1609 & 1.225 & 1.754 & 1.429 \\
\hline \multirow[t]{4}{*}{0.2} & 300 & 7500 & 72.6 & 3628 & 19.20 & 13.74 & 67.07 & 2418 & 1.134 & 1.810 & 1.182 \\
\hline & 400 & 5625 & 65.9 & 329.6 & 25.60 & 1586 & 58.54 & 2095 & 1143 & 1.824 & 1.320 \\
\hline & 500 & 4500 & 61.2 & 306.0 & 3200 & 19.00 & 49.00 & 1872 & 1.151 & 1.844 & 1.423 \\
\hline & 600 & 3750 & 57.6 & 287.9 & 38.40 & 22.17 & 39.42 & 1706 & 1.158 & 1.864 & i. 505 \\
\hline
\end{tabular}


These calculations confirm that metal-alloy fuels have breeding potential that is similar to that of mixed-carbide fuel.

B. Conclusions on Breeding Potential

1. Breeding ratios of large metal-fueled LMFBR's are estimated to be about 1.5 compared with about 1.25 for corresponding oxide-fueled LMFBR's. Since reactor doubling times vary approximately as $1 /(B R-1)$, doubling times for the metal-fueled reactors would be expected to be about half the doubling times for corresponding oxide-fueled reactors.

2. Detailed calculations of breeding ratios and doubling times for U-Pu-Zr-fueled systems are required to provide assurance that such systems have adequate potential to justify firther development. These calculations are also required to provide guidance on fuel-element design and operating conditions for experimental irradiations. 


\section{BURNUP POTENTIAL}

The design concept for metal fuels that has evolved--allowing for optimum fission-gas release--has demonstrated high burnup potential. Burnup potential is a key consideration in assessing the desirability of metallic fuels for use in advanced J.MFBR's. The largest body of data on the ir radiation behavior of fast-reactor fuels has been generated on the EBR-II driver fuel (U-5 wt \% Fs clad with solution-annealed (SA) $304 L$ and SA 316 stainless steel). However, significart, though limited, ir radiation results have also been cb. tained on the U-Pu-Zr and U-Pu-Ti fuel systems.

\section{A. Irradiation Experience with U-5 wt \% Fs System (E.BR-II Driver Fueli)}

The EBR-II driver-fuel element is composed of a U-5 wi \% F metallic fuel pin sodium-bonded to a stainless steel cladding. Two principal driverfuel-element designs (Mark IA and Mark II) have been employed. These designs are described in Table VIII. ${ }^{12}$ Some variations of the Mark II design have been

TABI.E VIII Comparisun uI Mark-IA and -II Fuel-elemient Debigne Irradiated in EBR-II':

\begin{tabular}{|c|c|c|c|c|}
\hline & \multirow[b]{3}{*}{ Mark IA } & \multicolumn{3}{|c|}{ Mark II } \\
\hline & & \multirow[b]{2}{*}{$\begin{array}{l}\text { Reference } \\
\text { cored }\end{array}$} & \multicolumn{2}{|c|}{ Expeririental Element: } \\
\hline & & & Fincapoulated & $\begin{array}{l}\text { Unencapoulated } \\
\text { and Encapoulated }\end{array}$ \\
\hline finrichment. at o, "ll & 425 & 670 & 13 and 60 & 640 \\
\hline sucl-pin welkht. & nit 0 & 517 & $5+4$ & $5+4$ \\
\hline ruel-pin lenuth. in & $13:$ & 135 & $1+2$ & $1+2$ \\
\hline Fuel-pin diameler. in & $01+4$ & 0130 & 0130 & 0130 \\
\hline ruel volume. in ' & 0220 & 0177 & 0168 & $018 \mathrm{~B}$ \\
\hline $\begin{array}{l}\text { Fuel ciladding } \\
\text { radial kap. in }\end{array}$ & 0006 & 0010 & 0010 & 0010 \\
\hline Cladding asll thacknese, in & 0004 & 0012 & 0012 & 0012 \\
\hline Clacitiınt OD, in. & $017+$ & 0174 & 0174 & 0174 \\
\hline Cladting material & SA Int1. & $S A \| t$ & SA $10+1$. & SA 30 tl. nat SA 31 . \\
\hline Elemeril length, in & 181 & $2+1$ & $2+1$ and 261 & 201 \\
\hline P!enum volume. in ' & $00+1$ & $0.1+5$ & $01+5.018+$ & 0 bet \\
\hline Plenum asa & Arzon & Arion & Helium & Arsun \\
\hline $\begin{array}{l}\text { Sodium level above } \\
\text { fuel. in }\end{array}$ & 0 b5 & 129 & 03.10 & 14 \\
\hline $\begin{array}{l}\text { Retrasner height above } \\
\text { tuel, li: }\end{array}$ & 0 to & $0 \times 0$ & 02.08 & $0=: n$. a.s nuner \\
\hline Reetrainer type & Solid & Diniple & $\begin{array}{l}\text { Rind. oplit rins. } \\
\text { o- dimple }\end{array}$ & Simple \\
\hline Spacer-wire dismeter. in & $00+9$ & $00+9$ & Nuns un elemunt & $\begin{array}{c}0 \text { oft } \\
\text { ILnen:epoule.ed only) }\end{array}$ \\
\hline Spacer-wire material & SA 1041 . & SA 116 & None & $\begin{array}{c}\text { SA sodi. } \\
\text { UUnercapeulated only. }\end{array}$ \\
\hline
\end{tabular}


experimentally irradiated in EBR-II, and these ise also shown in Table VIII. Sirce the Mark-II design, in concept, is the closest to optimum for metal fuels with respect to smear density, ratio of plenum volime to fuel volume, etc., only the irradiation results for Mark II will be discussed. The ir radiation results for Mark IA are discussed in datail in Ref. 3.

The experimental ir radiation programs for Mark-II fuel have been carried out in two simultaneous parts: encapsulated and unencapsulated irradiations. A rather large number of design variations were considered, such as: 64,80 , and $93 \%$ enrichments of ${ }^{235} \mathrm{U}$; two types of cladding (SA $304 \mathrm{~L}$ and SA 316): different types of restrainers to restrain axial fuel growth during irradiation; and different plenum/fuel volume ratios, which were achieved by using elerients of different lengths ( 24 and 26 in.) and slight pre-irradiation adjustments of the sodium leveis above the fuel (see Table VIII).

On.: of the principal objectives of these experimerits is to obtain information on the final cladding-failure $\operatorname{mode}(s)$ associated with the Mark-II driverfuel design. This information not only provides necessary input to the driverfuel programs, but may also provide design information for more advanced metal fuels (e.g., U-Pu-Zr systelis). Because a reasonably large number of cesign variations were to be tested, a large number of failures were required. Most of the run-to-failure program was carried out in encapsulated elements in EBR-II (subassembly X07I) in order to minimize the effect of the experiment on reactor plant factor. However, one subassembly $(X 180)$ containing unencapsulated elements was run to iirst failure, and a number of run-to-failure experiments with reference-core-design Mark-Il fuel are in progress, but have yet (as of June 1975) to achieve burnups at which failures arcexpected.

The experiment with encapsulated Mark-U driver fuel (designated X071H a of June 1975) having the design variations whown in Table VIII has contributed mcst of the information for establishing the burnup potential of metal fuels. This experiment has been ongoing in EBR-II since 1967 (initially as subassembly $\times 029)$ and has had 11 reconstitutions. ${ }^{13}$ All reconstitutions and reactor positions for this experiment have been planned so as to maintain a constant mean power-to-fiow ratio such that the operating temperatures and power ratings of individual fuel elements were kept is constant as possible. The experiment has produced 20 cladding failures for the $80 \%$ - and $93 \%$ enriched elements with SA $304 \mathrm{~L}$ cladding. Data on these failures are listed in Tables IX-XIV. (The statistical parameters given in the tablea are deacribed in Sec. IV.A.1 below.) One 93\%-enriched element has run to 16.1 at. \% burnup without failure. In addition, a number of encapsulated $64 \%$-enriched. 26-in.-long elements with both SA $304 \mathrm{~L}$ and SA 316 cleddings have becn irradiated to -9.3 at. \% maximum burnup in XO71H without failure (see Tables XV and XVI). 
TABLE 1X. Cladding Failures of Encapsulated Experimental Mark-II Elements with SA 304L Cladding: $93 \%$-enriched Fuel, 24 -in.-long Elements

\begin{tabular}{|c|c|c|c|c|c|c|c|c|c|}
\hline $\begin{array}{l}\text { Element } \\
\text { No. }\end{array}$ & $\begin{array}{c}\text { Restrainer } \\
\text { Typea }\end{array}$ & $\begin{array}{l}\text { Na Level. } \\
\text { in. }\end{array}$ & $\begin{array}{c}\text { Plenum } \\
\text { Volume. } \\
\text { in. }\end{array}$ & $\underset{\substack{\text { 'fax } \\
\text { of }}}{\text { clad }}{ }^{b}$ & $\begin{array}{c}\text { Axial } \\
\text { Failure } \\
\text { Location. } \\
17 .\end{array}$ & $\begin{array}{l}B U_{\max } \\
\text { at. } \sigma_{0}\end{array}$ & $\begin{array}{l}\text { Failure } \\
\text { Rank }\end{array}$ & $F\left(B U_{\text {max }}\right)$ & Remarks \\
\hline 7 total & - & - & - & - & - & $\leq 8.1$ & Unfailed & - & Suspended \\
\hline 205 & $\mathbf{A}$ & 0.36 & 0.149 & 1120 & 7.5 & 9.2 & 1.875 & - & From Xe71A \\
\hline 230 & C & 0.32 & 0.150 & 1130 & 7.5 & 9.2 & 3.750 & 0.240 & From $\times 071 \mathrm{~A}$ \\
\hline 203 & $\mathbf{A}$ & 0.46 & 0.147 & 1040 & 10.0 & 9.4 & 5.625 & 0.370 & From X071A \\
\hline 234 & B & 0.52 & 0.146 & d & - & 9.4 & Unfailed & - & $\begin{array}{l}\text { Suspended } \\
\text { after X071A }\end{array}$ \\
\hline 237 & C & 0.53 & 0.146 & 1070 & 7.7 & $\operatorname{lr} .0$ & 7.969 & 0.533 & From X071B \\
\hline 224 & C & 0.57 & 0.145 & 1 & d & 10.4 & 10.313 & 0.695 & From $\times 071 \mathrm{H}$ \\
\hline 232 & $\mathbf{A}$ & 0.48 & 0.147 & 1100 & - & 16.4 & Unfailed & - & $\begin{array}{l}\text { Still running } \\
\text { after } \mathrm{X} 071 \mathrm{H}\end{array}$ \\
\hline
\end{tabular}

$a_{A} \equiv$ split ring, $B$ E ring. $C \equiv$ dimple.

bMaximum time-averaged cladding temperature.

cDistance from bottom of fuel column.

do be determined. 
TABLE $X$. Cladding Failures of Encapsulated Experimental Mark-II Elements with SA 304L Cladding: $93 \%$-erriched Fuel, 26 -in.-long Elements

\begin{tabular}{|c|c|c|c|c|c|c|c|c|c|}
\hline $\begin{array}{l}\text { Element } \\
\text { No. }\end{array}$ & $\begin{array}{l}\text { Restrainer } \\
\text { Type }\end{array}$ & $\begin{array}{l}\text { Na Level, } \\
\text { in. }\end{array}$ & $\begin{array}{l}\text { Plenum } \\
\text { Volume, } \\
\text { in. }\end{array}$ & $\mathrm{T}_{\substack{{ }^{\circ} \mathrm{F} \\
\mathrm{clad}}} \mathrm{b}$ & $\begin{array}{c}\text { Axial } \\
\text { Failure } \\
\text { Location, }{ }^{c} \\
\text { in. }\end{array}$ & $\begin{array}{l}B J_{\max } \\
\text { at. } \%\end{array}$ & $\begin{array}{l}\text { Failure } \\
\text { Rank }\end{array}$ & $F\left(B U_{\max }\right)$ & Remarks \\
\hline 7 total & - & - & - & - & - & $\leq 7.9$ & Unfailed & - & Suspended \\
\hline 256 & $\mathbf{A}$ & 0.83 & 0.176 & d & - & 10.4 & Unfailed & - & Erom $\mathrm{X071H}$ \\
\hline 263 & $\mathbf{A}$ & C. 50 & 0.182 & 1110 & 9.7 & 10.6 & 2.143 & 0.128 & From $\times 071 \mathrm{C}$ \\
\hline 266 & $\mathbf{B}$ & 0.86 & 0.176 & 1070 & 9.5 & 10.8 & 4.285 & 0.277 & From X071C \\
\hline 256 & A & 0.88 & 0.175 & d & $d$ & 11.0 & 6.429 & 0.426 & From $\times 071 \mathrm{H}$ \\
\hline 267 & C & 0.84 & 0.176 & 1090 & 8.5 & 12.1 & 8.571 & 0.574 & From X071E \\
\hline 205 & $\mathbf{A}$ & 0.91 & 0.175 & 1060 & 12.5 & 12.6 & 10.714 & 0.723 & From $x 071 \mathrm{E}$ \\
\hline 288 & c & 0.36 & $0.18 ?$ & 1000 & - & 13.3 & Unfailed & - & From $\mathrm{X0?1 \textrm {C }}$ \\
\hline 285 & $\mathrm{C}$ & 0.36 & 0.184 & 1060 & d & $(14.9)^{\mathrm{e}}$ & $(12.857)^{e}$ & $(0.872)^{\mathrm{e}}$ & $\begin{array}{l}\text { Failed in } \times 071 H \text {, which } \\
\text { had } 16.2 \text { at. } \% B U_{\max }\end{array}$ \\
\hline
\end{tabular}

$a_{A} \equiv$ split ring. $B \equiv$ ring. $C \equiv$ dimple.

baximum time-averaged cladding temperature.

Distance from bottom of fuel cclumn.

do be determined.

Best estimates. Exact burnup at tiñe of element failure is not known 
TABLE XI. Cladding Failures of Encapsulated Experimental Mark-II Elements

with SA $304 \mathrm{~L}$ Cladding: $80 \%$-enriched Fuel, 24-in,-long Elements

\begin{tabular}{|c|c|c|c|c|c|c|c|c|c|}
\hline $\begin{array}{l}\text { Element } \\
\text { No. }\end{array}$ & $\begin{array}{c}\text { Restraizer } \\
\text { Typea }\end{array}$ & $\begin{array}{l}\text { Na Level. } \\
\text { in. }\end{array}$ & $\begin{array}{c}\text { Plenum } \\
\text { Volume. } \\
\text { in. }\end{array}$ & $\mathrm{T}_{\substack{\mathrm{i} \operatorname{lad}_{\mathrm{F}} \\
\max }} \mathrm{b}$ & $\begin{array}{l}\text { Axial } \\
\text { Failure } \\
\text { Location. } \\
\text { in. }\end{array}$ & $\begin{array}{l}B U_{\max } \\
\text { at. } \%\end{array}$ & $\begin{array}{c}\text { Failure } \\
\text { Rank }\end{array}$ & $F\left(B U_{\max }\right)$ & Remarks \\
\hline 11 total & - & - & - & & - & $\leq 8.2$ & Unfailed & - & Suspended \\
\hline 200 & C & 0.49 & 0.147 & 1050 & 9.5 & 10.2 & 3.75 & 0.240 & From X071E \\
\hline 209 & $\mathbf{A}$ & 0.39 & 0.149 & 1030 & 8.5 & 10.4 & 7.50 & 0.500 & From X071E \\
\hline 202 & C & 0.31 & 0.150 & 1050 & 9.0 & 10.5 & 11.25 & 0.760 & From X0715 \\
\hline
\end{tabular}

Maximum time-averaged cladding temperature.

CDistance from bottom of fuel column.

TABLE XII. Failure Data Used in Analysis of 80\%-enriched, 24-in.-long

Encapsulated Experimental Mark-Il Elements with SA 304 L Cladding

\begin{tabular}{cccc}
\hline $\begin{array}{c}\text { BU } U_{\text {max }} \\
\text { at. \% }\end{array}$ & $\begin{array}{c}\text { Failure } \\
\text { Fraction }\end{array}$ & $F\left(B U_{\max }\right)$ & Remarks \\
\hline 9.4 & 0.3 & $0.017^{\mathrm{a}}$ & X071D results \\
10.2 & $2 / 3$ & 0.500 & X071E results \\
10.4 & $3 / 3$ & 0.794 & X071E and X071F results
\end{tabular}

$\mathrm{BU}_{0}-8.9$ at. $\%: \beta=4.03: \eta=1.38 ; \mathrm{R}^{2}=99.7 \%$ (explanation of variance).

${ }^{a}$ Reliability of three elements assumed to be 0.95 . 
TABLE XIII. Cladding Fallures of Encapsulated Experimental Mark-II Elements with SA $304 \mathrm{~L}$ Cladding: $80 \%$-enriched Fuel, 26-in.-long Elements

\begin{tabular}{|c|c|c|c|c|c|c|c|c|c|}
\hline $\begin{array}{l}\text { Filement } \\
\text { No. }\end{array}$ & $\begin{array}{c}\text { Restrainer } \\
\text { Type }\end{array}$ & $\begin{array}{c}\text { Na Level. } \\
\text { in. }\end{array}$ & $\begin{array}{c}\text { Plenum } \\
\text { Volunie. } \\
\text { in. }\end{array}$ & $\mathrm{T}_{\substack{\mathrm{cla} \\
\mathrm{f}}}^{\max }{ }^{b}$ & $\begin{array}{c}\text { Axial } \\
\text { Failure } \\
\text { Location. } \\
\quad \text { in. }\end{array}$ & $\begin{array}{l}B U_{\max } \\
\text { at. } \%\end{array}$ & $\begin{array}{c}\text { Failure } \\
\text { Rank }\end{array}$ & $F\left(B U_{\max }\right)$ & Remarks \\
\hline 5 total & - & - & - & - & - & 58.4 & Unfailed & - & Suspended \\
\hline 275 & $\mathbf{A}$ & 0.41 & 0.184 & 1070 & $12 . t$ & 11.3 & 1.625 & - & From X071G \\
\hline 284 & $\mathbf{A}$ & 1.00 & 0.173 & 1070 & 9.0 & 11.3 & 3.250 & 0.238 & From X071G \\
\hline 269 & C & 0.40 & 0.184 & d & d & 13.2 & 4.875 & 0.369 & From X071H \\
\hline 276 & $\mathbf{A}$ & 0.92 & 0.175 & d & d & 13.3 & 6.500 & - & From X071H \\
\hline 277 & $\mathbf{B}$ & 0.40 & 0.184 & d & d & 13.3 & 8.125 & 0.631 & From $X 071 \mathrm{H}$ \\
\hline 287 & $\mathbf{B}$ & 0.77 & 0.177 & d & d & 13.5 & Unfailed & - & From $\times 071 \mathrm{H}$ \\
\hline 270 & C & 0.97 & 0.174 & d & d & 13.7 & 10.563 & 0.828 & From X071H \\
\hline
\end{tabular}

a $A$ eplit ring. $B \equiv$ ring. $C \equiv$ dimple.

Maximum time-averaged cladding temperature.

CDistance from bottom of fuel column.

do be determined. 
TABLE XIV. Failure Data Used in Analysis of 80\%-enriched, 26-in.-long Encapsulated Expcrimental Mark-II Elements with SA $304 \mathrm{~L}$ Cladding

\begin{tabular}{|c|c|c|c|}
\hline $\begin{array}{l}B U_{\max } \text {. } \\
\text { at. } \%\end{array}$ & $\begin{array}{l}\text { Failure } \\
\text { Fraction }\end{array}$ & $\mathrm{F}\left(B U_{\max }\right)$ & Remarks \\
\hline 10.4 & $0 / 7$ & $0.0073^{\mathrm{a}}$ & X07IF results \\
\hline 11.1 & $2 / 7$ & 0.230 & X07JG results \\
\hline 13.5 & $6 / 7$ & 0.770 & Y.07IG and $X 071 H$ results \\
\hline
\end{tabular}

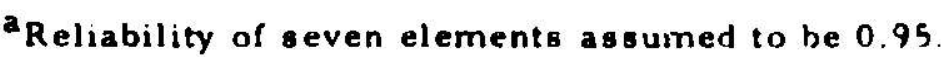

TABLE XV. Status of 64\%-enriched. 26-ın--iong Encapsulated Experiniental Mark-11 Elements with SA 304L Cladding

\begin{tabular}{|c|c|c|c|c|c|}
\hline $\begin{array}{c}\text { Element } \\
\text { No. }^{a}\end{array}$ & $\begin{array}{l}\text { Na Level. } \\
\text { in. }\end{array}$ & $\begin{array}{c}\text { Plenum } \\
\text { Volume. } \\
\text { in }\end{array}$ & $T_{\substack{\operatorname{lnad} \\
F}} b$ & $\begin{array}{l}B U_{\max } \\
\text { at. } \%\end{array}$ & Status \\
\hline 11 & 1.5 & 0.164 & 1024 & 2.8 & Unfailed \\
\hline 3 & 1.5 & 0.164 & 954 & 8. 5 & Unfailed \\
\hline 10 & 1.5 & 0.164 & $10+8$ & 8.6 & Unfailed \\
\hline 6 & 1.5 & 0.164 & 1028 & 8. 8 & Unfailed \\
\hline 1 & 1.5 & 0.164 & 1062 & 9.3 & Unfailed \\
\hline
\end{tabular}

a Fuel restrainers all dimple type.

${ }^{b}$ Maximum tume-averaped cladding temperature.

TABLE XV1. Status of 64\%-enriched, 26-in.-long Encapsulated Experimental Mark-Il Elements with SA 316 Claddink

\begin{tabular}{|c|c|c|c|c|c|}
\hline $\begin{array}{c}\text { Element } \\
\text { No. }\end{array}$ & $\begin{array}{l}\text { Na Level, } \\
\text { in. }\end{array}$ & $\begin{array}{c}\text { Plenum } \\
\text { Volume. } \\
\text { in.' }\end{array}$ & $T_{c \mid F}^{\max }{ }^{b}$ & $\begin{array}{l}\mathrm{BU}_{\max } \\
\text { at. } \%\end{array}$ & Status \\
\hline 12 & 1.5 & 0.164 & 1066 & 7.5 & Unfailed \\
\hline 7 & 1.5 & 0.164 & 1020 & 8.6 & Unfailed \\
\hline 17 & 1.5 & 0.164 & 986 & 9.2 & Unfailed \\
\hline 15 & 1.5 & 0.164 & 986 & 9.4 & Unfailed \\
\hline
\end{tabular}

Fuel restrainere all dimple type.

baximum time-avelaked cladding iemperature. 
A large number of unencapsulated 64\%-enriched, 26-in.-long elements have been ir radiated to 6 at. \% maximum burnup in six standard 7 :-element driver-fuel subassemblies. Abcut two-thircis of the initial 556 elements achieved 6 at. \% maximum burnup: about half of these elements were clad with SA $304 \mathrm{~L}$, and the other half with SA 316. No cladding failures occurred in this portion of the experimental program (up to 6 at. $\% \mathrm{BU}_{\text {max }}$ ); the irradiation results are reportud in Ref. 14.

The unencapsulated-irradiations program with $64 \%$-enriched, 26 -in.long e!ements was continued from the 6 at. $\% \mathrm{BU}_{\max }$ level with 37 elements clad only with SA 316 . This final experiment, X180, produced a single fasiure at 9.3 at. \% $B U_{\max }$ as shown in Table XVII." The peak cladding temperatures (at the inside cladding wall at the top of the fuel column) in $\times 180$ are calculated to range from 970 to $1070^{\circ} \mathrm{F}\left(-1060^{\circ} \mathrm{F}\right.$ lor the failed element).

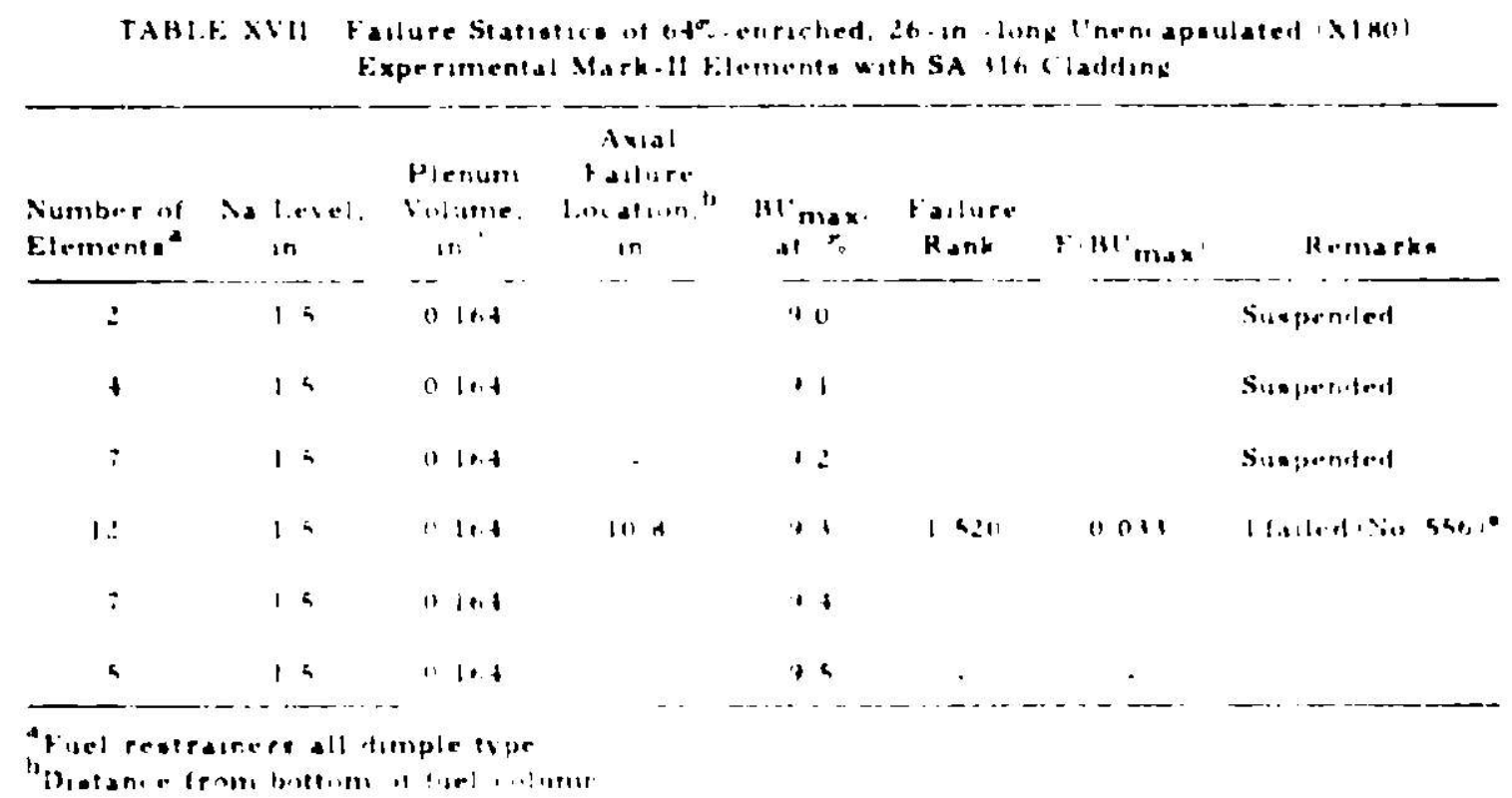

In addition to the previously described encapeulated and unencapaulated experiments, there is a large ongoing run-to-failure program associated with the 67\%-enriched. SA-316-clad, 24-in.-long reference Mark-ll design (oee Table VIII). At present (June 1975), 91 elements have been irradiated up to 6 at. \% BU $\max$. and 4459 element have been irradiated to the current 4.7 at. \% burnup limit without a single element tailure. is

\section{Statistical Analyais of Cladding Failures}

Since end-of-design-life failures have occurred only with the U-5 wt \% metal driver-fuel alloy with stainless steel cladding. the otatiotical analysis of failures must by necensity be 1 imited to this system. Only the re sults for the encapsulated $80 \%$ - and $93 \%$-enriched fuel with SA $304 \mathrm{~L}$ clading will be enalyzed. Before etutistical aralyeie of fallures may be performed, a suitable statistical failure model must be chosen or determined.

If h Math-II i lad with SA BIC. 
Since its publication, ${ }^{16}$ the Weibull failure model has received considerable attention because of $1 t s$ versatility in producing good agresment with data in a number of reliability-oricented industries. ${ }^{16-21}$ Application of the Weibull morlel fo fallures of reactor fuel elements was first made in 1954 at the Hanford production reactors and never failed to provide all adequate description of the fuel-clement fallure data, a prime requirement in mpirical model building. ${ }^{22}$ Recently, the model has provided a very good statistical description of fallures of Mark-1A Ariver fuel in EBR-II.' Theoretically, the Weibull distribution is applicable when one is concerned with the iailure of an item in which a large number of flaws exist and the failure depends upon the severest llaw in the system. Hence, the theoretical bacis for the Weibull model is that it is a reasinable description of what leads to failure. The basic W cibull distribution function may be written as

$$
f(x)=1-\exp \left[-\left(\frac{x-x_{0}}{T_{1}}\right)^{\beta}\right] .
$$

where

$$
\begin{aligned}
\mathbf{x} & =\text { time-deperdent variable. } \\
\mathbf{F}(\mathbf{x}) \text { - } & \text { cumulative failure probability at } \mathbf{x} \text {. or the fraction of the } \\
& \text { population accounted for. } \\
\mathbf{x}_{0}= & \text { origin of the distribution }\left[F\left(\mathbf{x} \leq x_{0}\right)=0\right] . \\
\eta & \text { scaling parameter }(>0) . \\
\eta+x_{0} & \left.=\text { characteristic life }\left[F(\pi)+x_{0}\right)=63 \%\right] .
\end{aligned}
$$

and

$$
\text { = shape parameter, or Weibull slope }(>0) \text {. }
$$

Next, one requires a method to determine the best estimates for the observet failure probabilities. All the failure data that will be analyzed here came (rom the X07I experiment with encapoulated fuel (Tables $(X-X I V)$ : hence, we do not know the exact burnup or time of failure. But we do know the cumulative probability of failure at any time the experiment was examined. Thus we choose to work with the cumulative failure probability (Eq. I) for th: analysis.

The binomial correction employed by . Johnso.:23 wae used in ae - essing the failure probabilities from the data (Tables IX-XIV). This correction is necessary because. for small eample sise, there is a better than even chance that a larger iallure fraction will be observed than dictated by the actual median fallure probability. Instead of uning the actual observed failure frac. tion, we used the simplified binomial interpretation of the cumulative failure probability." 


$$
F(x)=\frac{j-0.3}{N+0.4}
$$

where $j$ is the number of failures observed out of $N$ observations, or the rank order number. The correction is relatively small for $\mathrm{N}>10$.

Another correction is required when suspended items are involved. This approach is covered in detail by Johnson in Ref. 23; the expression for the increment in failure rank $(\Delta n)$ is

$$
\Delta n=-\frac{(N+1)-(\text { previous rank order number })}{1+(\text { number of items beyond present suspended item })}
$$

The relationship between Eqs. 2 and 3 is

$$
j=\sum_{i=i}^{j} \Delta n_{i}
$$

Equations 2 and 3 were used to assess the failure probabilities in Tables IX, X, XI, and XIII. Some of the data points for $80 \%$-enriched fuel in Tables XI and XIII have burnup intervals too close together to achieve valid analysis for the entire data sets. Therefore. we used the last known burnup at which there were no failures (assuming $95 \%$ reliability at such burnups). and applied averaging teciniques to obtain at least three well-conditioned $d$.ta points from Tables $X I$ and XIII; those points are listed in Tables XII and XIV. The best-estimate Weibull jarameters for the respective data sets are shown in Tables IX, X, XII, and XIV.

Although there were not enough data points to satistically test all design parameters, there is a definite difference between 24 - and 26 -in. - long SA-304L-clad elements. The difference is basically an additional 1.5 at. \% BUmax capability for the longer elements, which may be indicative of the larger plenums of those clements. There are no fa:lures for the encapsulated 64\%-enriched elements with SA $304 \mathrm{~L}$ or SA 316 cladding (Tables XV and XVI). The only failure for the unencapsulated $64 \%$-enriched fuel is with SA $304 \mathrm{~L}$ cladding ( $T$ able $X V I I$ ). Further conclusions will have to await more irradiation results. The experimental failure statistice for data accumulated thus far are graphically illuutrated in Fig. 2, along with the lines describing the results calculated from the respective Weibull parameters.

\section{Cladding Fracture Modes}

The failure mode(s) for encapeulated. SA - 304L-clad Mark-Il elemente has not been fully established. Many of the early-burnup failurea a. oociated with the 93\%-enriched 24 -in. elemonts (see Table $(X)$ exhibited omall 


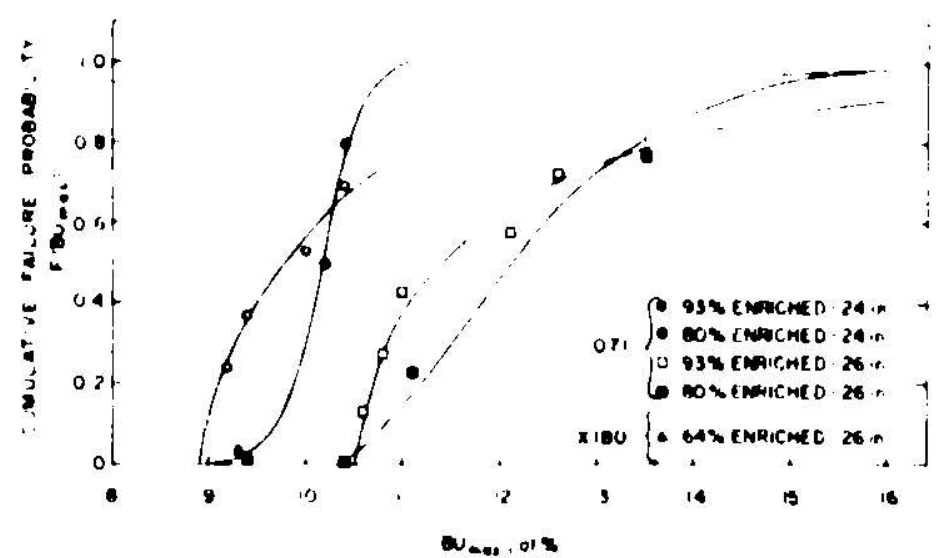

Fig. ". Tumulative Fallute Probability ss Maximum Burnup for Varialiens in Design of Mark-11 Iriver Fucl. ANL Neg. No, 103-T532" longitudinal cladding cracks, but later (in time) (ailures with higher neutron doses (e.g., Table XIII) and larger cladding s'welling tend to exhibit "pinholes" and are rather difficult to locate. All the cladding failures located thus far have been $7.5-12.5 \mathrm{in}$. above the bottom of the fuel pin, as noted in Tables IX - XIV.

To date (June 1975), only one failure of a Mark-II element has been examined in detail, ${ }^{24}$ but the results are worth re-

viewing. Scanning-elertron-microscopy (SEM) evaluation of the fracture surface from the SA $304 \mathrm{~L}$ cladding of encapsulated element 230 (see Table IX) frcm experiment X07IA was completed at LASL. This cladding was observed to have failed $7.5 \mathrm{in}$. from the bottom of the fuel column when the element was examined at 9.2 at. $\% \mathrm{BU}_{\max }$. Some of the irradiation parameters of interest at the failure location were: $16.1 \%$ cladding volume swelling. $2.4 \%$ mechanical hoop strain, $5.8 \times 10^{22} \mathrm{n}, \mathrm{cm}^{2}(\mathrm{E}>0.1 \mathrm{MeV})$ fluence, and peak calculated cladding temperature of $1078^{\circ} \mathrm{F}$ at the inner wall.

A typical region of the fracture surface is shown in Fig. 3. The fuel/ cladding interaction zor.e $(20 \%$ of the 0.012 -in. cladding thickness) is to the left of the arrow. The region to the right of the arrow (toward the outer cladding surface) exhibits a very ductile region, with the dimples indicating the dirction of fracture propagation from the outside to the inside of the cladding yall. There was considerable evidence of stress corrosion, as is appires: in Fig. 4, with the attack shown on the outer surface of the cladding adjaz: $n$ t to the fracture surface. The fracture surface observed in this examination was far more ductile in appearance than that observed for the Mark-IA design (see Ref. 3), even though both designs of driver fuel have similar uniform hoop strains at the fracture locations. (Mechanical hoop strains averaging $2 \%$ are readily achievable before failure of SA $304 \mathrm{~L}$-clad Mark-II elements.") Peak SA 304L cladding volume swellings of up to $23 \%$ before failure have been measured by immersion density.

\section{Cladding-diameter Change}

A considerable amount of data on cladding-diameter change as a function of irradiation exposure has been generated for both SA-304L-clad 

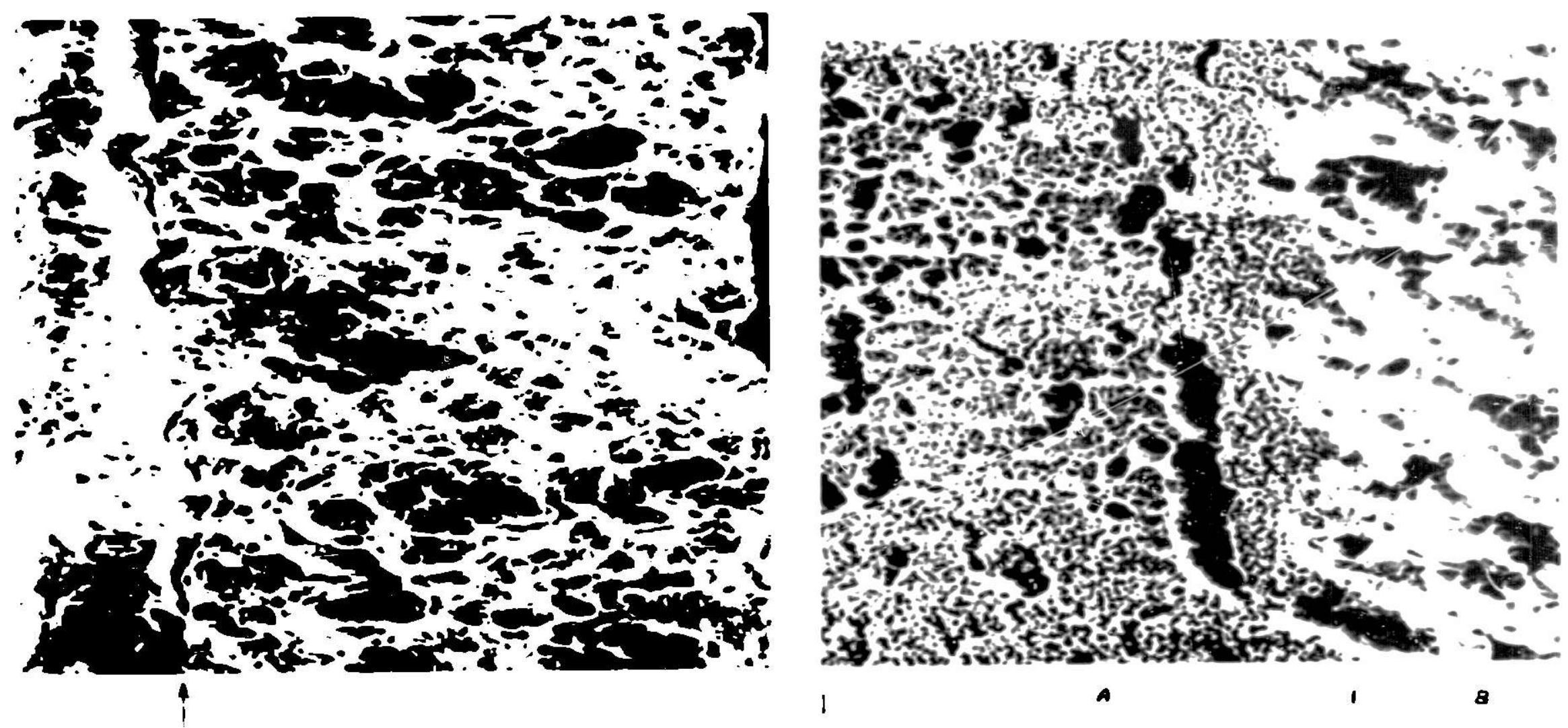

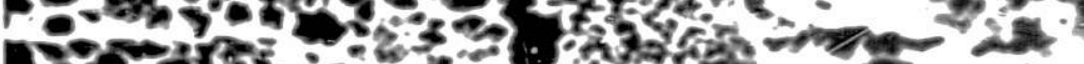
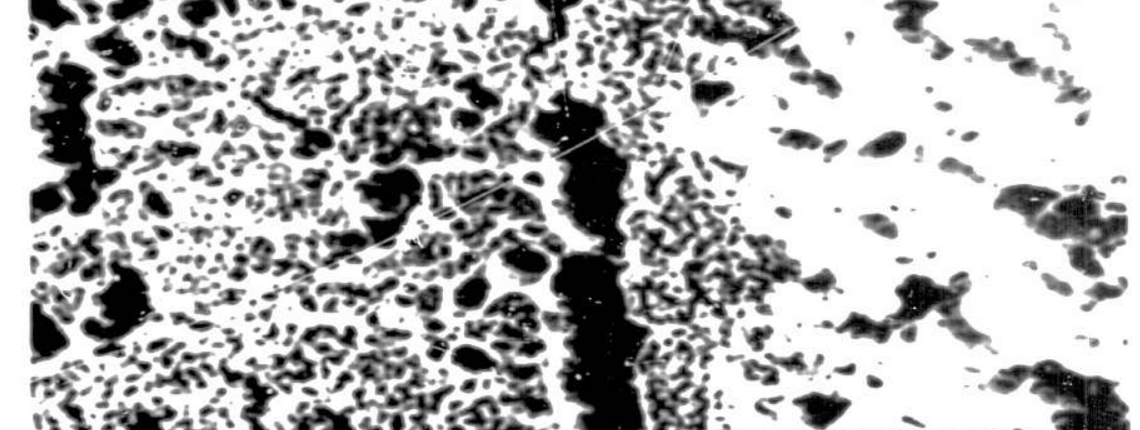

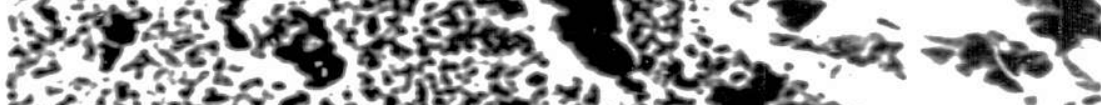

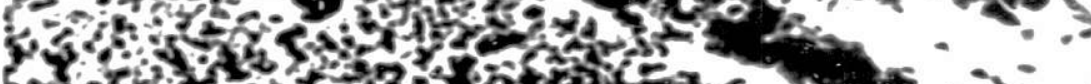

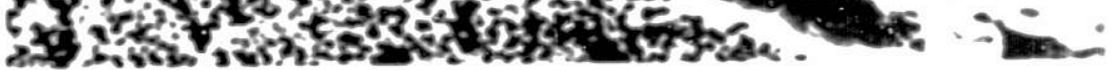


and SA-316-clad Mark-11 elenents. These data are summarized in Fig. 5 in terms of maximum burnup. The data points have been omitted from the figure to improve clarity; the lines represent necan values for the maximum diameter changes of several individual elements. The results are plotted two ways: (1) the maximum diameter cisange due to cladding swesling $\left(\Delta \mathrm{V} / \mathrm{V}_{0}\right)$ and (2) the total neasured naximun diameter chanfe (total strair). The swelling is measured by immersion density, and $L D_{\max }^{8 / 4 e l !} D_{0}$ is assumed equal to ( $A \mathrm{~V}$ $\left.V_{0}\right)$ 3. The $\Delta D_{\text {max }} D_{c}$ ! ir an individual elemerie normally occurs above the core midplane. The difference between the total diameter change and the coniribution of swelling 10 it is an estimate of the mechanical hoop strain. Two fluence scales are guven to encompass the range of fluence-to-burnup ratios caused by the different ith Uenrichments.

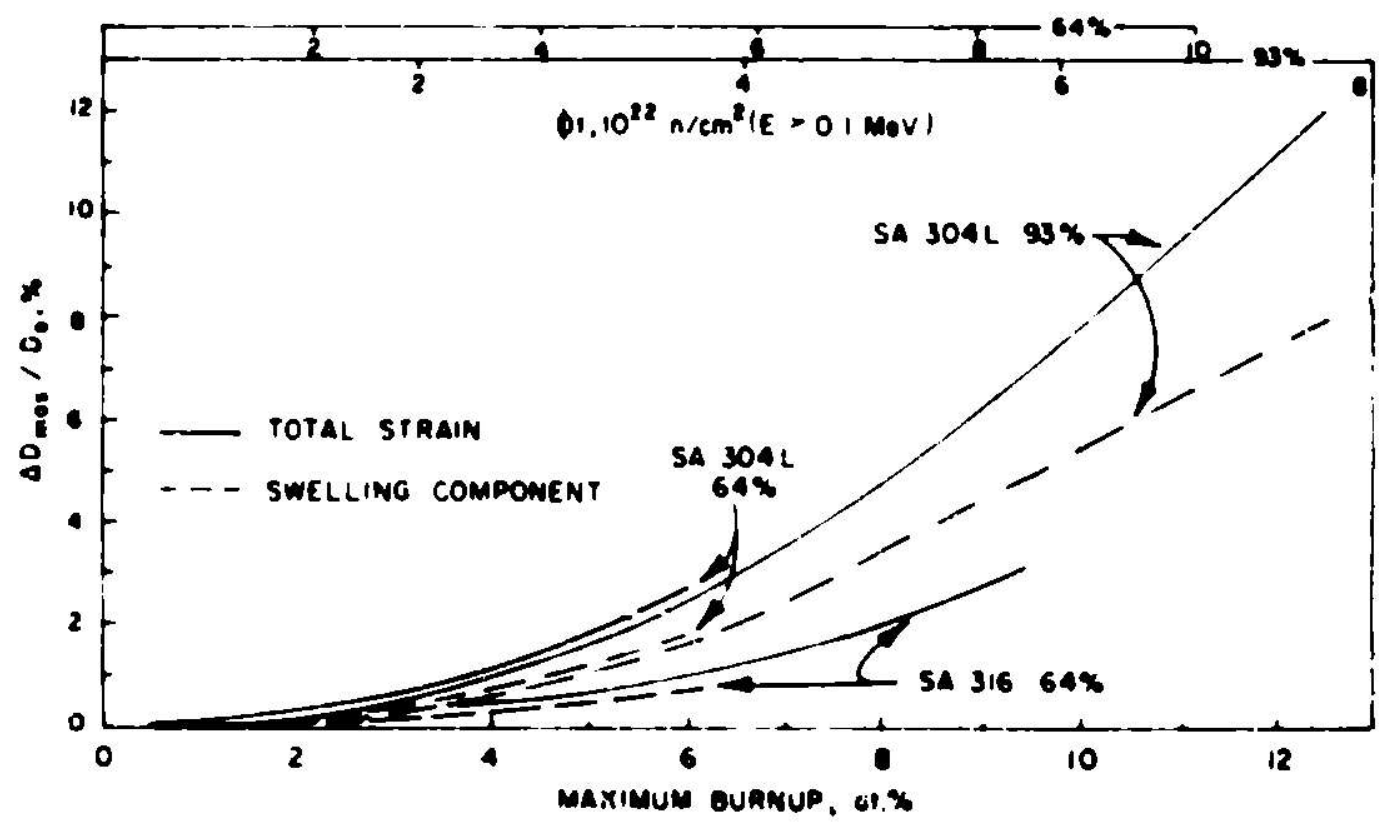

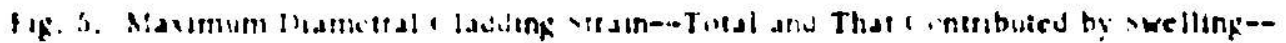

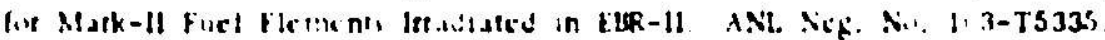

It appears possible: to achieve very large diameler changes with the SA-304l.-clad elenents prior to fallure. These large $\Delta D_{\text {max }} D_{0}$ values at high burnups result from large contributions from both welling and mechani. cal hoop strain. The synergistic effect of teniperature, neutron dose, and stress on $\Delta D_{\text {max }} D_{0}$ are not known. but the dillerence between the performance of SA 316 and SA 3041 cladding is illustrated reanonably well in Fig. 5. The figure also shows what appears to be a nearly constant ratio between the contributicors of swellins and mechanical strain to $\Delta D_{\max } D_{0}$.

13. U-Pu-Zr Fuel System

For a rretal fuel to be considered in the L.MFBR program, it must be a plutonium-bearing alloy (containing 10-2:0 we ${ }^{\circ}$. Pul that is conpatible with 


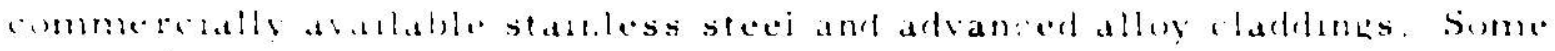

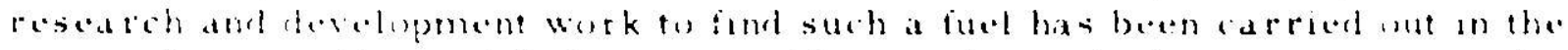
past at Arwmne Katuonal l.dboratory. This work resultert in a promising ad-

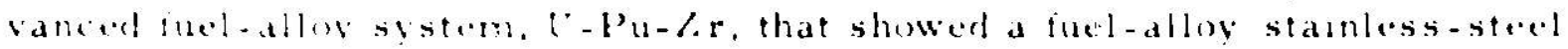

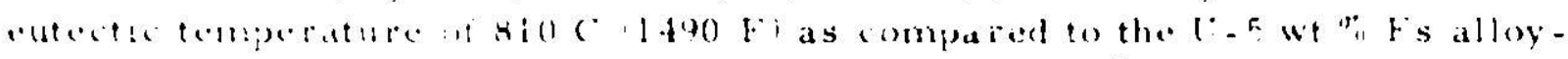

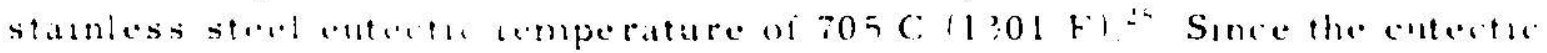
temperature is lite as sumed limiting variable for the applation of anctal fuels

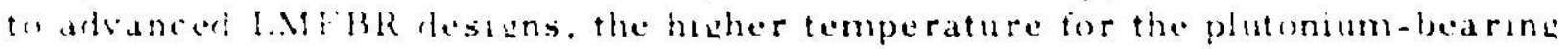
metal luet alloy as stendifeant.

A number at in - and out-of-pole experiments hate been completed with

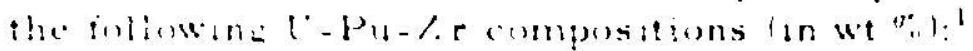

$$
\begin{aligned}
& \text { 1. } \quad[-15 p u-10 / . r \text {. }
\end{aligned}
$$

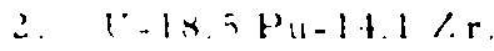

$$
\begin{aligned}
& \text { 3. }\left[0-i 0 \cap P_{t}-6\right) 3 / r \text {. } \\
& \text { +. } \quad \because-1=P_{1,-1 / R} \\
& \Rightarrow \quad r-1+1+12 / \mathrm{r} \\
& \text { i) } \quad 1-1=1+12 \% \text {. }
\end{aligned}
$$

The arst irrartations of L'-Pu-Zr alloys were performed on prototype

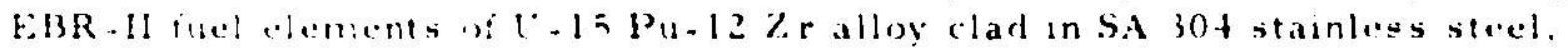
SA 3lestabless steel. Hastelloy-X. and $V .20 \mathrm{~T}$ alloy. The elements were

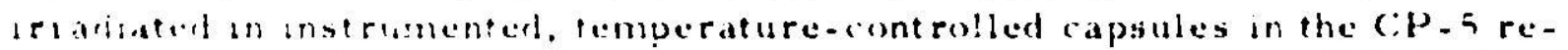
actorto $2 t$ is. "burnup at a maximum cladding temperature of $1130 \mathrm{~F} 1610 \mathrm{C:})^{\prime}$

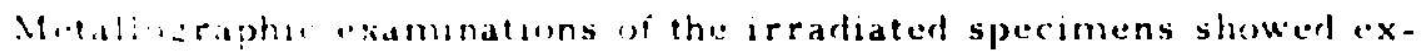

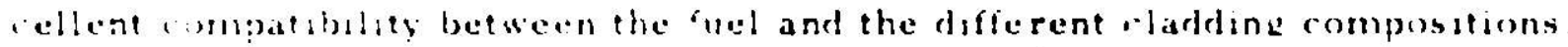

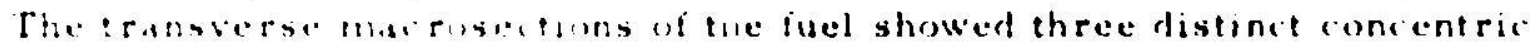
bands which are rolaterl to phase distributions existing at the temperature of

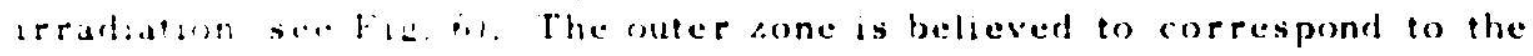

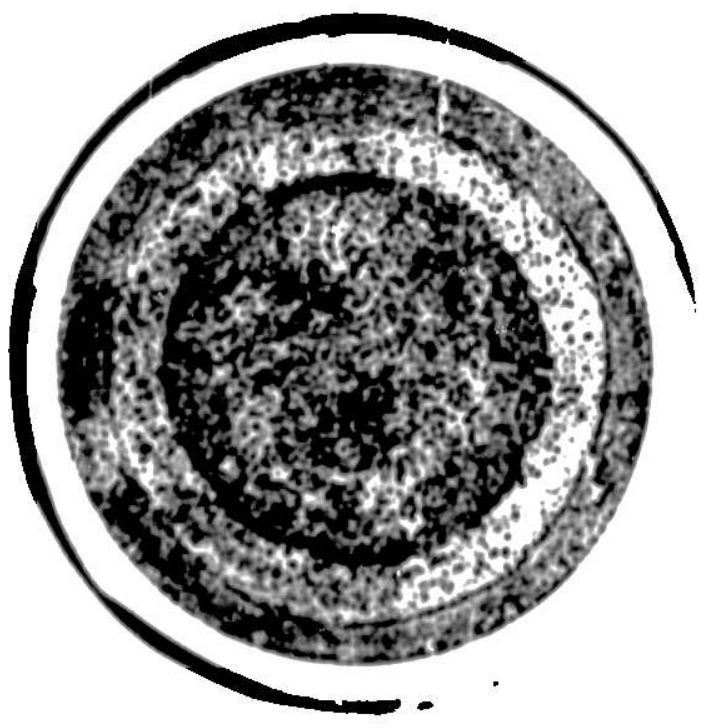

fis: "

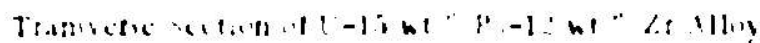

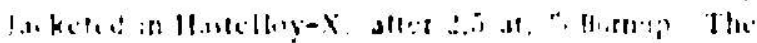

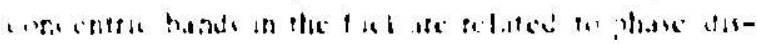

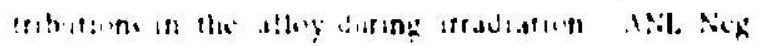
$\therefore \quad 1 \therefore-\cdots 1 \cdot$ 
alpha-uranium + delta + zeid phase, the second band to the alfha-uranium: zeta + gamma phase, and the central area to the samma piase The fuel had swelled to the internal diameter of the cladding, and the bond sdium was er tirely displaced into the gas plenum. Figure 6 also show that he original void volume. which had existed as a sorlium-filled annulus aroind the solio metal fuel pin at the start of ir radiation, became redistributed throughout the fuel volume in the form of finely civided porosity

Irradiation of the U-Pu-Zr element ciarl in $V-20 \mathrm{Ti}$ alloy was contin'sei to 12.5 at $\%$ burnup at a maximum cladding temperature of $\left.1210: 51654^{\circ} \mathrm{C}\right)$. Periodic neutron radiography of the capsule during irradiation showed that the fuel attained a maximum elongation of $3 \%$ within the claddıng, which occurred at 4.2 at. \% burnup. This dimensior. did not change throughout the remainjer of the irradiation.

An average 0.0002 -in. increase of the oripinal claddinf diameter of $0.174 \mathrm{in.}$ was measured. No measurasle length increase of the cladding was noted. It was determined that $74 \%$ of the fission gas had beer released to the plenum. The cladding was intact.

Because of the promising resulis obtained or. sraall prototype fut ele nents, irradiations were made on full-length elernents of $U-P u-Z r$ alloy in EBR II subassemblies XG05, XG06, XA07, and XC28.",36 Zable XVIII lists the. debign and operating parameters of those fuel elements and two others containing $\mathrm{U}-15 \mathrm{Pu}-10 \mathrm{Ti}$ fuel.

Fuel compositions in the EBR-Il irradiations were U-15 Pu-9 Z r, I]- $15 \mathrm{Pu}-10 \mathrm{Zr}$, and $\mathrm{U}-15 \mathrm{Pu}-12 \mathrm{Zr}$, with smeared densities ranging from 66 10 $75 \%$. Cladding included SA 304 and SA 316 stainless steel. Hastelloy $-X$. Iaste!loy-X-280, and V-20 Ti. All cladding was in the annealed state. Fucielemert dian.etirs were 0.196 or 0.208 in.. With wall thicknesses of 0.015 or $0.019 \mathrm{in.}$ The fuel pins were nominally $13 \mathrm{in}$. lo'g. with $0.144-$ in. diameters. Linsar heat ratings ranged from 9.1 to $10.5 \mathrm{~kW} / \mathrm{ft}$, and maximum cladiing terr.peratures ranged from 1021 to $1206^{\circ} \mathrm{F}\left(549\right.$ to $\left.652^{\circ} \mathrm{C}\right)$.

The most thoroughly evaluated EBR-LI irradiation data for the U-Pu-Zs fuel system are the results from the 16 encapsulated elements contained in s sbassemb:y XA07." These elements were irradiated to $4.0-4.6$ at. \% burnuf without cladding failure.

External dimensional measurements of the irradiated elements shovicd maximum diameter changes of $0.05-0.5 \%$ at the +.5 at. $\%$ burnup level. The:s: changen a re somewhat lower than would be expected with SA-316-stainlese. steel-clad U-5 wt \% Fs (see Fig. 5): however, the U-Pu-Zr elements had sinewhat larger plenums, so their ratio of hoop stress to plenum preseure wss lower. No immersion-dunsity measuroments were taken to determine the cladding swelling. Fuel-pin lengthe within the cladding were determined by 
TABi.E XVil: Dearn and Operaling Parameters lor U-Pu-Zr and U.Pu-Ti Fuel Irradialed in EBR-1I

\begin{tabular}{|c|c|c|c|c|c|c|c|c|c|}
\hline \multirow{2}{*}{$\begin{array}{c}\text { Fuel } \\
\text { Composition. } \\
\text { n }\end{array}$} & \multirow[b]{2}{*}{$\begin{array}{l}\text { Element } \\
\text { No. }\end{array}$} & \multirow{2}{*}{$\begin{array}{l}\text { EBR - U } \\
\text { SA } \\
\text { No }\end{array}$} & \multirow{2}{*}{$\begin{array}{l}\text { Fuel } \\
\text { Smeared } \\
\text { Deneity. } \\
\text { o TD }\end{array}$} & \multicolumn{3}{|c|}{ Cladding } & \multirow{2}{*}{$\begin{array}{l}\text { Max } \\
\text { Linear } \\
\text { Heat. } \\
k W \text { ft }\end{array}$} & \multirow{2}{*}{$\begin{array}{l}\text { Max } \\
\text { C.ladding } \\
\text { Temp. 'F }\end{array}$} & \multirow[b]{2}{*}{$\begin{array}{c}\text { Burnup. } \\
\text { al }\end{array}$} \\
\hline & & & & Material & OD. & $\begin{array}{c}\text { Thack. } \\
\text { in. }\end{array}$ & & & \\
\hline \multirow[t]{4}{*}{ U - IS Pu-9 Zr } & ND.2A & XA07 & 73 & 30455 & 0.205 & 0.019 & 10.9 & 1206 & 4.6 \\
\hline & ND. 32 & & 74 & 316 SS & 0196 & 0.015 & 9.9 & 1164 & 42 \\
\hline & ND.\&I & & it & $30+5 S$ & 0.205 & 0.019 & 10.4 & 1197 & 4.4 \\
\hline & ND.43 & & 75 & Hast - $X$ & 0.196 & 0015 & 104 & 1180 & 4.4 \\
\hline \multirow[t]{17}{*}{$\mathrm{U}-15 \mathrm{~Pa} .10 \mathrm{Zr}$} & BA.01 & $\mathrm{x} 028$ & 79 & $30+1$ SS & 0.196 & 0.015 & 9.4 & 1182 & 0.77 \\
\hline & BA.02 & & 75 & 304L SS & 0196 & 0.015 & 94 & 1152 & 0.77 \\
\hline & BA-0 & & 75 & 3041 SS & 0196 & 0015 & 94 & 1182 & 0.77 \\
\hline & BA.04 & & 75 & $304 L$ SS & 0.196 & 0.015 & 95 & 1184 & 0.78 \\
\hline & BA-OG & & 75 & $304 L$ SS & 0.196 & 0.015 & 94 & 1182 & 0.77 \\
\hline & SB.01 & & 75 & $304 L$ SS & 0205 & 0.020 & 9.5 & 1184 & 0.78 \\
\hline & BC.OI & & 75 & 31655 & 0196 & 0015 & 94 & 1182 & 0.77 \\
\hline & BC. -02 & & 75 & 316 SS & 0.196 & 0.015 & 95 & 1384 & 0.78 \\
\hline & $\mathrm{BC}-\mathrm{O}_{3}$ & & 75 & 31655 & 0196 & 0.015 & 94 & 1182 & 0.77 \\
\hline & SD.03 & & 76 & $V-20 \mathrm{~T}_{2}$ & 0.195 & 0.015 & 94 & 1182 & 0.77 \\
\hline & $\mathrm{B}^{\prime \prime}: .04$ & & 76 & $V .20 T_{1}$ & 0195 & 0.015 & 94 & 1182 & 077 \\
\hline & AD-05 & & 76 & $V-20 \mathrm{~T}_{2}$ & 0194 & 0015 & 94 & 1182 & 0.77 \\
\hline & BE-UI & & 76 & $V \cdot 20 T_{2}$ & 0195 & 0.015 & 94 & 1182 & 0.77 \\
\hline & BE.02 & & 76 & $V=20 T_{1}$ & 0195 & 0.015 & 94 & 1182 & 0.77 \\
\hline & $B E-0\}$ & & 76 & $V-20 \mathrm{Tl}$ & 0.195 & 0.015 & $9+$ & 1182 & 0.77 \\
\hline & ND - 23 & XG06 & 65 & $\mathrm{~V} .20 \mathrm{~T}$ & 0209 & 0.016 & 108 & 1184 & 4.2 \\
\hline & ND.24 & XGOS & 65 & $\mathrm{~V} .20 \mathrm{Tl}$ & 0209 & 0016 & 108 & 1184 & 50 \\
\hline \multirow[t]{12}{*}{ U-15 Pu. $12 \mathrm{Zr}$} & ND-25 & XA07 & 74 & $30+55$ & 0205 & 0019 & 95 & 1144 & 4.0 \\
\hline & ND-26 & & 74 & 316 SS & 0196 & 0.015 & 95 & 1121 & 40 \\
\hline & ND. 27 & & 73 & $30+55$ & 0.205 & 0.019 & 9.7 & 1154 & 41 \\
\hline & ND-24 & & 72 & 31655 & 0196 & 0.015 & 95 & 1132 & 40 \\
\hline & ND. 30 & & 72 & 316 SS & 0196 & 0015 & 104 & 1168 & 4.4 \\
\hline & ND. 31 & & 74 & 316 SS & 0.196 & 0.015 & 99 & 1155 & +2 \\
\hline & ND.33 & & 73 & Hast $-x$ & 0196 & 0015 & 97 & 1155 & +2 \\
\hline & ND.34 & & 73 & Hast - $X$ & 0196 & 0.015 & 99 & 1161 & 42 \\
\hline & ND. 35 & & 75 & llace $-x$ & 0197 & 0.015 & 104 & 1173 & $4 t$ \\
\hline & ND.37 & & 65 & Hast $-X-280$ & 0207 & 0015 & In 4 & 1170 & $4+$ \\
\hline & ND. 39 & & 65 & Hant - X-280 & 0207 & 0015 & 10.2 & 1164 & +3 \\
\hline & ND-44 & & 66 & Hase: - X-280 & 0208 & 0015 & 99 & 1152 & 42 \\
\hline U. 15 Pu.10 TI & $\begin{array}{l}N C-17 \\
N C-23\end{array}$ & $\begin{array}{l}\text { XC05 } \\
\text { XC06 }\end{array}$ & $\begin{array}{l}64 \\
68\end{array}$ & $\begin{array}{l}V-20 T_{1} \\
V .20 \mathrm{Tl}\end{array}$ & $\begin{array}{l}0204 \\
0.204\end{array}$ & $\begin{array}{ll}0 & 016 \\
0.016\end{array}$ & $\begin{array}{l}108 \\
108\end{array}$ & $\begin{array}{l}1184 \\
1184\end{array}$ & $\begin{array}{l}56 \\
42\end{array}$ \\
\hline
\end{tabular}

Based on salyses ,i neodymium or technetium 
neutron radiography, which disclosed an average length increase of $1.9 \%$. The irradiated fuel pins were r.ct seated on the bottom closures of the cladding, but were elevated an average of $0.20 \mathrm{in}$. The elements had been intentionally assembled without fuel restrainers to observe possible axial fuel movement. The neutrca radiographs revealed one or two partial axial separations, which varied from 0.02 to $0.96 \mathrm{in}$. in width, in most of the fuel pins within the cladding.

Measurements of fission-gas recovery showed that $60-71 \%$ of the fission gas had been released from the high-burnup fuel alloy to the plenum above the bond sodium. Detailed metallographic and microprobe examination 3 of the fuel/claddinif interfaces showed reaction zones that had a maximurn depth of $0.005 \mathrm{in}$. ir the Hastelloy $-\mathrm{X}$ and the $\mathrm{SA} 304$ stainless steel, and $0.001 \mathrm{in}$. in the SA 31 ś stainless steel.

Irradiation of a group of encapsulated U-15 Pu-10 $\mathrm{Zr}$ fusl elements clad with SA 304 and SA 316 stainless steel in EBR-II subasser.bbly X028 (see Table XVIII) was terminated at 0.77 at. \% burnup when capsule BC -02 and its contained element failed. It appeared that the capsule failed first, so the capsule bond sodium was removed and the fuel element overheated. Irradiation of this group of fuel elements was discontinued primarily because of concern regarding the weld quality of the remaining capsules. Postirradiation examination showed that in all elements the fuel had swelled into contact with the cladding. ${ }^{26}$

Two U-15 Pu-10 Zr fuel elements clad with 0.016-in.-thick V-20 Ti alloy were irradiated in EBR-II subassemblies XG05 and XG06 to burnups of 5.6 and 4.2 at. $\%$, respectively. ${ }^{26}$ The peak linear heat rating was $10.8 \mathrm{~kW} / \mathrm{ft}$, and the maximum cladding temperature was $1184^{\circ} \mathrm{F}\left(640^{\circ} \mathrm{C}\right)$. Element ND-24, irradiated in subassembly XG05, released $57 \%$ of its fission gas into the element plenum. Microprobe analysis showed infiltration of sodium into the porous fuel, with local concentrations of $1-6$ wt \%.

A number of other metallurgical features of the U-Pu-Zr system are considered in Sec. $V$ below. That Jiscussion will consider the influence of fuel-cladding eutectic and solidus temperatures on high-teniperature irradiation performance.

C. U-Pu-Ti Alloys

The U-Pu-Ti alloy system, like the U-Pu-Zr system, is potentially attractive because of the high melting points of alloys of interest. However. U-Pu-Ti alloys are not as compatible with stainless steel as U-Pu-Zr alloys. Only a limited number of irradiations were performed; all the fuel was clad in V-20 Ti alloy.' A prototype element was irradiated to 10.7 at. \% burnup in a thermal-reactor ir radiation, ${ }^{9}$ and two full-length elements were ir radiated to burnups up to 5.6 at. \% in EBR-11. ${ }^{26}$ 
D. Conclusions on Burnup Potential

1. The high-burnup potential of properly designed LMFBR rnetal fuel elements is shown by the demonstrated capability of EBR-II Mark-II driver fuel to reliably ferform at burnups greater than 10 at. \%. This Mark-II design concept could be used with an LMFBR metal fuel such as U-Pu-Zr.

2. Successful EBR -II irradiations were made with stainless steelclad U-Pu-Zralloy fuel eiements to burnups of $\sim 4.5$ at. \%, which demonstrated the feasibility of this fuel system with peak cladding temperatures of $1200^{\circ} \mathrm{F}$ $\left(649^{\circ} \mathrm{C}\right)$.

3. Information on irradiation performance is needed at high burnups $(>4.5$ at. $\%)$ to establish the burnup potential of the U-Pu-Z r metal fuels clad with 20\%-coldworked Type 316 stainless steel and with advanced alloys such as PE16. The design and operating parameters for these irradiations should reflect guidance from the systems studies recommended in paragraph 2 of Sec. III.B. 


\section{THERMAL PERFORMANCE}

A major consideration for evaluating applicability of fuels for LMFBR's is the maximum coolant lemperature at which the fuel design will satisfactorily perform. Many early metal-alloy fuels have suffered from substantial linitations in this critical area. Of particular current interest are stainless steelclad U-Pu-Zr alloy fuels, which are less thermally limited than any other stainless steel-clad plutonium-containing metallic fuel studied to date.

When thermal-performance limits for U-Pu-Zr fuels are considered, the following three areas must be addressed; these are discussed in detail later in this section.

1. Fuel/Cladding Compatibility. Of greatest importance is the temperature at which a fuel-cladding eutectic forms, resulting in an accelerated rate of cladding deterioration. Another important consideration is the rate of fuel/cladding interdiffusion that occurs below the eutectic temperature. This interdiffusion results in a gradual loss of effective cladding thickness with time, and may limit the burnup potential.

2. Fuel Melting. Because fuel melting may result in undesirable rapid changes in reactivity or in greatly accelerated cladcing-penetration rates, it should be avoided during normal operation.

3. Fuel Slumping. The fuel should not slump significantly (shorten by creep under its own weight) during normal reactor operating conditions. The effect of fuel slumping on reactor safety is considered in Sec.VIl. The U-Pu-Zr alloys, like most metallic fuel alloys, are compatible with oodium, and sodium is commonly used as a thermal bond between the fuel and the cladding. While this compatibility is taken for granted in metallic fuels, it is an important consideration in the use of other fuel types (e.g., oxides and carbides). particularly when running beyond cladding failure.

Two thermal considerations, not unique to metallic fuels, are the cladding mechanical strength and ductility and the cladding corrosion in sodium coolant. These are not discussed in detail in this report, but a brief otatement on them is in order.

First, the strength and ductility of cladjing must be adequate to withstand the stress/time history imposed by thermal, gas-pressure, and fuelpreasure stresses. This consideration is not unique to metallic fuels, but both the relative contributions of these three otresses and the cladding otrese state may be unique.

Second, excess: re wastage or detrimental change in important propeitie of the cladding by the flowing primary-sodium coolant must be avoided. Sodium corrosion can compromise cladding integrity as well as revult 
in excessive deposition of activated chemical elements from the cladding in the reactor regions outside the core (e.g., pumps, heat exchangers, etc.). This deposition can greatly increase difficulties in maintaining these components: but, again, it is not unique to metallic fuels.

A. Fuel/Cladding Compatibility

1. Fuel-Cladding Eutectic Temperature

One critical parameter for uranium-base alloy fuels clad with irun- or nickel-base alloys is the fuel-cladding eutectic temperature. Table XIX summarizes the available compatibility tata for unirradiated U-Pu-Zr fuel alloys and compares them with data for other metallic fuel systems.* The important point to note is the high eutectic temperature $\left(1515 \pm 45^{\circ} \mathrm{F}\right)$ found for the combination of SA 304 stainless steel and U-Pu-Zr fuel containing 10 wt \% or more of zirconium. This is well above any other metallic fuel-stainless steel eutectic temperature we are aware of $\left(\mathrm{e} . \mathrm{g}\right.$. , it is about $195^{\circ} \mathrm{F}$ above the eutectic temperature of the U-5 wt \% Fs and SA 316 stainless steel of the EBR-II Mark-II driver fuel). It is $180^{\circ} \mathrm{F}$ above the U/Fe eutectic temperature and $740^{\circ} \mathrm{F}$ above the $\mathrm{Pu} / \mathrm{Fe}$ eutectic temperature. It is expected that the eutectic temperature for the U-Pu-Zr/Type 316 stainless steel system would be similar to that obtained with the U-Pu-Zr/SA 304 stainles s steel syotem.

Future LMFBR designs may require low-swelling and stronger cladding materials if burnup limits are not to be reotricted. Hence, the fuelcladding eutectic temperatures of $\mathrm{U}-\mathrm{Pu}-\mathrm{Zr}$ fuel and a number of advanced cladding alloys are also presented in Table XIX. The compositions of these alloys are listed in Table XX. Although the alloys are not ones currently being considered in the advanced-cladding-alloys programs. for the purpose of compatibility studies their compositione can be considered representative of advanced cladding alloya. Except for the high-nickel-content Incoloy 800 and Hastelloy-X alloys, the listed alloys exhibit essentially the same fuel-cladding eutectic temperatures as those with SA 304 etainless stcel.

The irradiztion in EBR-II (in subassembly XAO7) of U-15 wt \% Pu-10 wt \% Zr fuel clad with SA $304 \mathrm{~L}$ stainless steel, with SA 316 stainlesa steel, with Hastelloy-X, and with Hastelloy-X-280 to maximum busnupe of 4.5 at. \% and at maximum cladding temperatures of $1200^{\circ} \mathrm{F}$ showed no formation of the fuel-cladding eutectic." This provides come confirmation of the out-of-resctor results of Table XIX, but does not give the required information on actual eutectic temperatures for irradiated fuel and cladding.

It is reaconable to ask what rates of cladding penetration would occur if the fuel/cladding interface temperatures exceed the fuel-cladding eutectic temperatures. Exceeding the outectic temperature is not acceptable under normal operating conditions, becalise the ratec are too rapid. For offnormal conditione (mild overpower or reduced flow). however, the eutectic temperatures can be exceeded for short times without cladding fallure. Because

-The alloy Jeignated $8 z$ is identical to the alloy Fi. except that it ha a ilighily highet sirconium coateat. 
TABLF. XIX, Fuel-Ciladding Filte.els Temperatureg ('F)

\begin{tabular}{|c|c|c|c|c|c|c|c|c|c|}
\hline \multirow[b]{2}{*}{ Fuel Alloy. wi } & \multicolumn{9}{|c|}{ Ciladding Matrerial } \\
\hline & $30+\mathrm{SS}$ & $316 \mathrm{SS}$ & $r$. & $\begin{array}{c}\text { Imken } \\
16 \cdot 15 \cdot 6^{a}\end{array}$ & $\begin{array}{c}\text { limken } \\
16-25 \cdot 6^{2}\end{array}$ & Haynes $5 b^{a}$ & $x-155^{a}$ & $\begin{array}{c}\text { In: oloy } \\
n 00^{\mathrm{a}}\end{array}$ & Hastelloy- $x^{a}$ \\
\hline$\therefore 15 \mathrm{Pu}-10 \mathrm{Zr}^{27}$ & $1515 \cdot 15$ & $\cdot$ & - & $1515 \cdot+5$ & $<1560$ & $1515 \cdot+5$ & $<1560$ & $1+30 \cdot+5$ & $1335 \cdot 45$ \\
\hline $\mathrm{U}-16.6 \mathrm{Pu}-6.3 \mathrm{Zr}^{21}$ & $1335 \cdot 45$ & $\cdot$ & - & - & - & - & $\cdot$ & - & $1335: \$ 5$ \\
\hline $\mathrm{U}-18.5 \mathrm{Pu}-14.1 \mathrm{Zr}^{27}$ & $1515 \cdot 45$ & $\cdot$ & - & $1535 \cdot 30$ & $<1560$ & $1515 \cdot 45$ & $1515 \cdot+5$ & $1515 \cdot 35$ & $1335 \cdot 45$ \\
\hline U-15 Pu-10 Ti ${ }^{21}$ & $<1290$ & $\cdot$ & - & & - & - & & - & $\cdot$ \\
\hline$U-5 F e^{20}$ & $1300: 10$ & $1320 \cdot 10$ & - & $\cdot$ & - & $\cdot$ & $\cdot$ & $\cdot$ & $\cdot$ \\
\hline$U-15 P u-10 F z^{20}$ & $1220 \cdot 25$ & - & - & - & - & - & - & $\cdot$ & \\
\hline Uransum (ualloyed) & - & $\cdot$ & $1335 \cdot 5$ & - & $\cdot$ & - & - & & $\cdot$ \\
\hline Plutonium (unslloyed)" & - & - & $775 \cdot 5$ & - & - & - & - & - & - \\
\hline
\end{tabular}

compositione ere given in Table $x x$ 
TABLE XX. Composition of Advanced Cladding Alloys

\begin{tabular}{|c|c|c|c|c|c|c|c|}
\hline \multirow[b]{2}{*}{ Alloy } & \multicolumn{7}{|c|}{ Composition, wt \% } \\
\hline & $\mathbf{F e}$ & $\mathrm{Ni}$ & $\mathrm{Cr}$ & Mo & Co & $w$ & $M n$ \\
\hline Timken 16-15-6 & 55 & 15 & 16 & 6 & - & - & 7.5 \\
\hline Timken 16-25-6 & 50 & 25 & 16 & 6 & - & - & 1.3 \\
\hline Haynes 56 & 46 & 13 & 21 & 4.5 & 11.5 & 1.5 & 1.5 \\
\hline$N-155$ & 30 & 20 & 21 & 3 & 20 & 3 & 1.5 \\
\hline Incoloy 800 & 46 & 32 & 21 & - & - & - & 0.75 \\
\hline Hantelloy - X & 18 & 48 & 22 & 9 & 1.5 & 0.6 & 1.0 \\
\hline
\end{tabular}

no information has been generated on cladding penetration above the eutectic temperature for otainless oteel-clad U-Pu- $\mathrm{Zr}$ fuel, we will attempt to infer its behavior from results obtained on the U-5 wi \% F/SA 304 stainless stecl system. ${ }^{32-34}$ These studies have shown that, at temperatures elightly above the melting point of uranium or the liquidus of uranium-fiesium, $U-F$ alloys wil! penetrate stainless steel or iron at the rate of about $10 \mathrm{mils} / \mathrm{sec}$. Reference 34 also explored the maximum penetration rates of uranium through irun at temperatures between the uranium-irolt eutectic temperature and the uranium melting point. The following penetration rates were found: $0.01 \mathrm{mil} / \mathrm{min}$ at $1365^{\circ} \mathrm{F}, 0.76 \mathrm{mil} / \mathrm{min}$ at $1565^{\circ} \mathrm{F} .3 .1 \mathrm{mils} / \mathrm{min}$ at $1745^{\circ} \mathrm{F}$. and $8.5 \mathrm{mils} / \mathrm{min}$ at $1925^{\circ} \mathrm{F}$. It is not unreasonable to assume that the penetration rates of $U$ Pu-Zr alloys through Type 316 stainless steel would be of the eame order when their eutectic temperature of $-1515^{\circ} \mathrm{F}$ is exceeded. Therefore. excecding the eutectic temperature of stainlese steel-clad U-Pu-Zr fuels by as much a $200^{\circ} \mathrm{F}$ (or hort times (of the order of $1 \mathrm{~min}$ ) does not imply gross fue!-element iailures due to eutectic formation.

\section{Solid-otate Interdiffuoion between Fuel and Cladding}

Extensive penetration of fuel components into the cladding or loes of cladding components into the fuel below the eutect:c temperature could compromise the ability of the cladding to contain the fuel at high burnup. Table XXI summarizes available results of out-of-pile fuel-penetration test below the fuel-cladding eutectic temperature for U-Pu-Zr fuel alloy and rompares them to results obtained with other metallic fuel avotems. The data presented in this table are only for etainlese steel. Much more limited penetration data (usually single points at short timeo) were generated on the advanced alloys listed in Table $X X$. These data gen.rally howed penetration rates eimilar to thone obtained for SA 304 tainlese steel, except that the high-nickel alloye showed higher penetration ratee. Although the effec" of fuel penetration on the mechanical propertien of the stainlese steele in Table XXI is not really known. a relative comparison is posalble. For example, the penetration at $1300^{\circ} \mathrm{F}$ of the U-Pu-Z: alloye into SA $3 G 4$ stainlese steel ranges from 15 to $20 \%$ of that found for the U-5 Fe eystem. Hence, there is some improvigment with the 


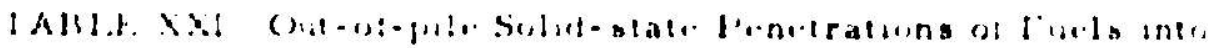

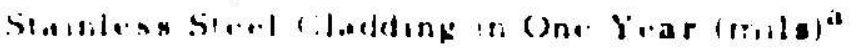

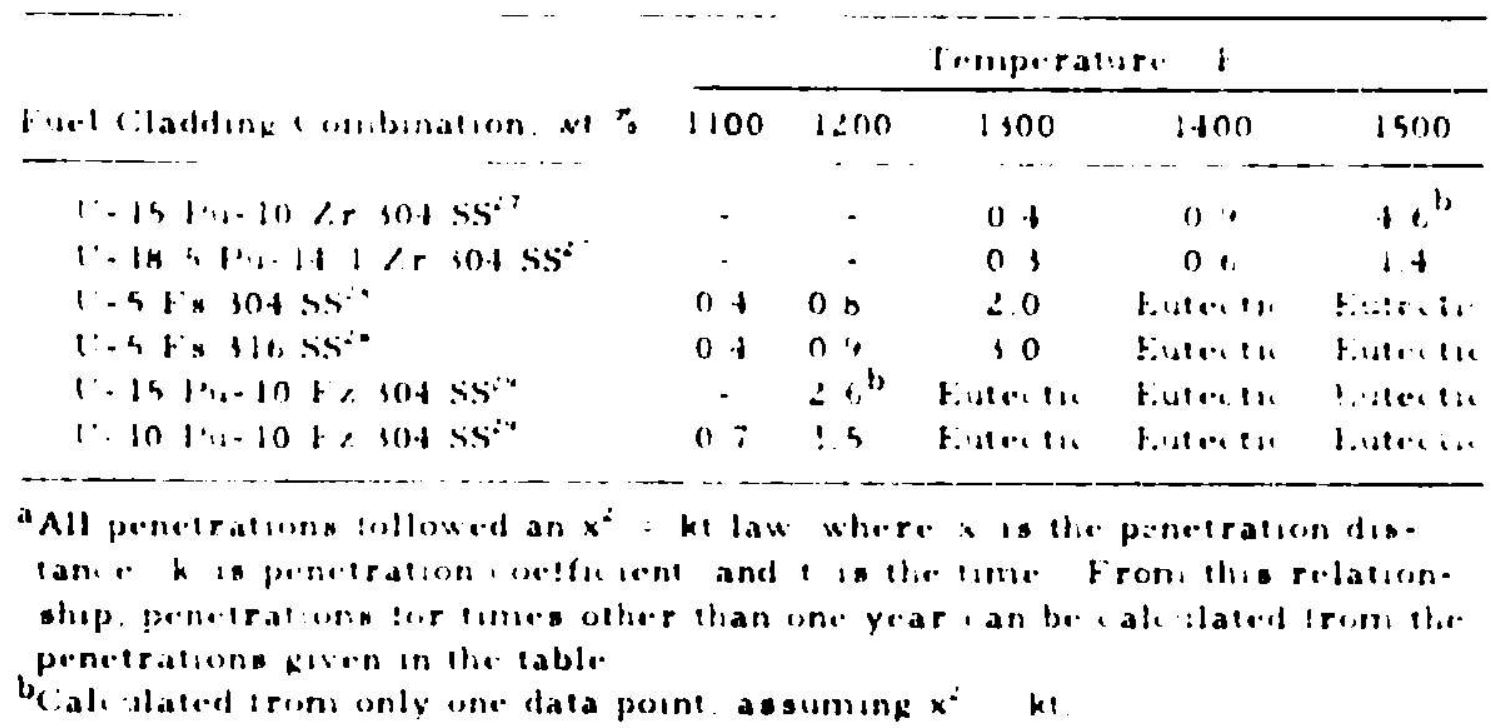

ternury alloy over a fuel syotem used as the EBR-Il driver fuel, which has shown good burnup potential (see Sec. IV). The significant conclusion that can be drawin from Table XXI is that, in the abecnce of irradiation, fuel/cladeing interdiffusion in the U-Pu-Zr/otainlese steel oyetem is not a significant problem at anticipated LMFBR temperaturea.

Of additional interest in the metal-fuele prograrn is the diffusion of stainless etecl cladding components into the uranium-base fuel. Nickei and. to come extent. iron diffuse oul of the austenitic cladding into the fuel. thereby increasing the chromium content in the interdiffusing region of the claddir With the loss of the austentic etabilizer, nickel, the austenitic etructure transforms to ferrite and otgma phases. Thio embrittling otructure can lead to cracking upon thermal cycling. Interdiffusion bands of $-3 \mathrm{mils}$ are not unconmon for SA-304L-etainlese-eteel-clad experimental Mark-II driver fuel (12-mil cladding thicknese) prior to failure in EBR-Il. This observation may be compared with the following review.

Some data on the effect of irradiation on interdiffusion between U. $15 \mathrm{wt} \% \mathrm{Pu}-10 \mathrm{wi} \% \mathrm{Zr}$ fuel and stainles ateel are available from the irradiation of fuel elements in E.BR-II experiment XA07. These elen.onts were operated at maximum fuel/ciadding-interface temperatureo of $1200^{\circ} \mathrm{F}$ to a burnup of 4.5 at. \%. Thie burnup wae equivalent to six monthe of full-power operation. Table XXIl oummarizes the cladding penetrationa observed during postirradiation examination of these elemente. In addition, tire table includes in-reactor penetratione extrapolated to one year uoing both $x^{2}=$ kt (the unual penetration-rate law) and $x$ y kt (the law for the most rapid penetration rate oeen in- or out-of-reactor), and extrapolated out-of-rsector penotratione extrapolated uning $x^{2}=k t$. 


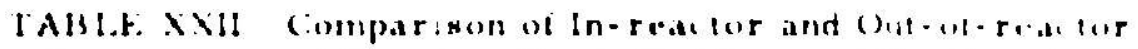

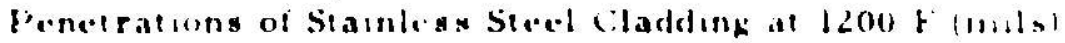

\begin{tabular}{|c|c|c|c|c|}
\hline \multirow[b]{3}{*}{$\begin{array}{c}\text { Iuel Claddink combination } \\
\text { we }\end{array}$} & \multicolumn{3}{|c|}{$\ln -\mathbf{r} \cdot \mathbf{a}, \operatorname{lo} r$} & \multirow{3}{*}{ 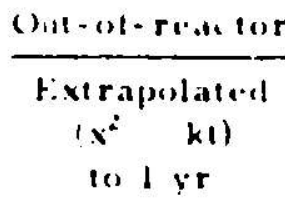 } \\
\hline & $\therefore|1, a|$ & Extrapolated & Fistrapolated & \\
\hline & 111110 & $\begin{array}{ll}\left(x^{2}\right. & k t) \\
t o & \mid y r\end{array}$ & $\begin{array}{l}\text { (x) k1) } \\
(1) 1 \text { yr }\end{array}$ & \\
\hline$\left[\because 15 \mathrm{Pu}_{\mathrm{u}}-10 \mathrm{dr}\right.$ 304 ss & 55 & 78 & 110 & 02 \\
\hline $\mathrm{t}=15 \mathrm{k}:-10 \mathrm{H}$ 110 Ss & 10 & 14 & $\therefore 0$ & $\cdot$ \\
\hline $\mathrm{U}=18 \mathrm{Pu}-1+2.530+\mathrm{SS}$ & $\cdot$ & - & . & 01 \\
\hline U.G Fs He SSa & . & $01^{b}$ & $01^{b}$ & $0+$ \\
\hline $0.5 \mathrm{~F}=10.4 \mathrm{~s} 5=$ & - & $10^{3}$ & $.0^{\prime \prime}$ & $0+$ \\
\hline
\end{tabular}

alpenetrations at $1100 . \mathrm{F}$

bA.tial neasired 1-year penetration

Two important pointe are noted from the data. First, the in-reactor penetration rate for the SA 316 stainleso steel is much les than that for the SA 304 stainlesen steel. Irradiation results for EBR-II driver fuel indicate that SA 316 stainles uteel is also more compatible than SA 304 stairless steel with U-5 wt \% F at temperatures up to $1100^{\circ} \mathrm{F} .14$ Although the difference in compatibility is not as great as seen in the irradiation results fcr U-Pu-Zr, it is significant. A difference in SA 316 stainlesesteel and SA 304 stainless steel was not seen for out-of-pile results on U-5\% Fs (sec Table XXII). A second and even more significant sbservation to be made for the U-Pu-Zr fuel is the much greater cladding penetration in-reactor than out-of-reactor. For the U.5 wt \% Fs/SA 304 stainless stecl combination, on the other hand, the cladding penetration (at $-1100^{\circ} \mathrm{F}$ ) was only elightly greater in-reactor than out-ofreactor. Additional irradiation data at higher cladding temperatures for longer times are eseential it U-Pu-Zr clad with stainlese steel is to be a viable LMFBR fuel element. Nevertheless, the modest in-reactor penetration $(-1 \mathrm{mil}$ in six monthe) of SA 316 stainles steel cladding) indicates that $13-15$ wt \% Pu- 10 wt $\% 2$ r clad with SA 316 ie a stisfactory high-burnup element, from the cumpatibility vi.upoint, at meximum cladding temperatures up $10-1200^{\circ} \mathrm{F}$.

\section{Compratibility Variables}

The high eutertic temperatures and low interdiffusion ratcs exhibited by U-Pu-Zr alloys with SA 304 stainlese steel may be influenced by the oxygen levels in the fuel and cladding. Electron-mic roprobe analyaea made on certain annealed diffusion couples indicated that compatibility inay be improved by the formation in the fuel of diffupion layers consisting of one or more zirconium-rich phases stabilized by oxygen. ${ }^{27}$ These phases may reatrict the iransport of iron and nickel into the fuel as well as diffusion of uranium and plutonium into the stainless oteel. The presence of oxygen at some level in the cladding and fuel alloy may therefore be beneficial, if not esential, for obtaining good compatibility in U-Pu-Zr/stainlese steel systems. It is important that this point be pursued further. 
A most interesing feature of this fuel alloy system is that, except for oxygen, the starting composition may not be as important for cdedding com-

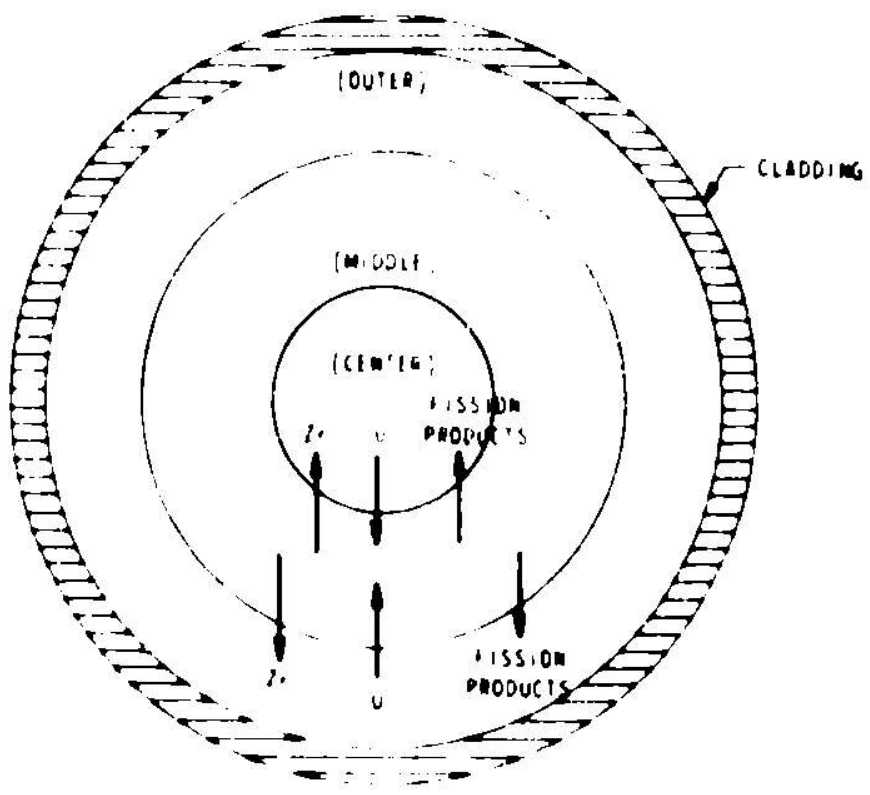

Fig. 7. Ittadiation Lones and Difusion Couples for (1-Pu-Lt Syvieni. ANL Neg. No, 103-89093. patibility as the out-of-pile studies indicate. During irradiation, when the fuel-centerline temperatures reach $-1380^{\circ} \mathrm{F}$, the fuel exhibits hree distinct metallurgical zones caused by compositional (phase) changes that are due to the temperature gradient from the center to the outside of the fuel pin and to ir radiation. These zones, schematically represented in Fig. 7. inay be physically separated.

Table XXIII liats the componition ranges along the fuel-pin lengths for these zones after the EBR-II ir radiation of U-Pu- $\mathrm{Zr}$ alloy 4 and 5 (s.eSec. IV.B) to 4.5 at. \% burnup. Comparison of these compositions with the solidus curves of Fig. 8 shows that the high zirconium content of the outer zone. adjacent to the cladding, would lead to an outer-zone coidus temperature higher than $2190^{\circ} \mathrm{F}$; this may result in beneficial compatibility effects. The middle zone has a solicius temperature below $1830^{\circ} \mathrm{F}$, while the center zone. with its higher zirconium content, again exceeds the $2190^{\circ} \mathrm{F}$ solidus temperature.

Beta-gamma autoradiograph" show that active fission products diffuse into the outer and center zones in a similar manner to the natural and stable isotopes of zirconium. There is very little net radial novement of the

TABLE XXI1I. Mean and (Range of) Atomic Percentages of

Plutonium. Zirconium, and Uranium in Irradiation Zonea of Alloys 4 and 5 after 4.5 at. \% Burnup

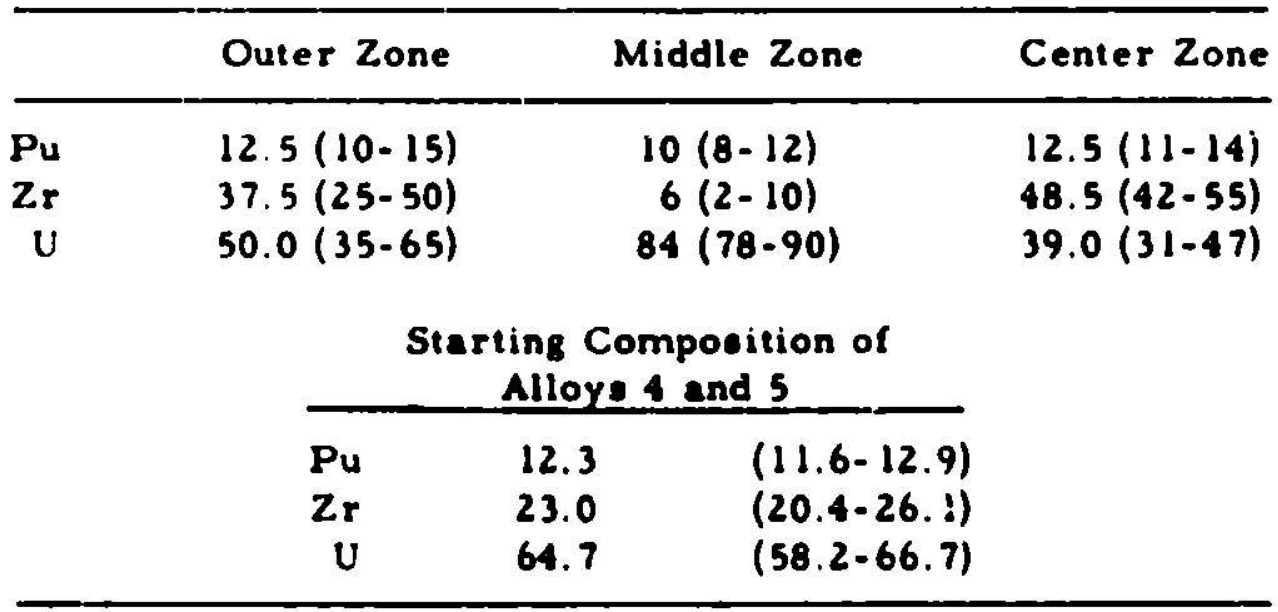




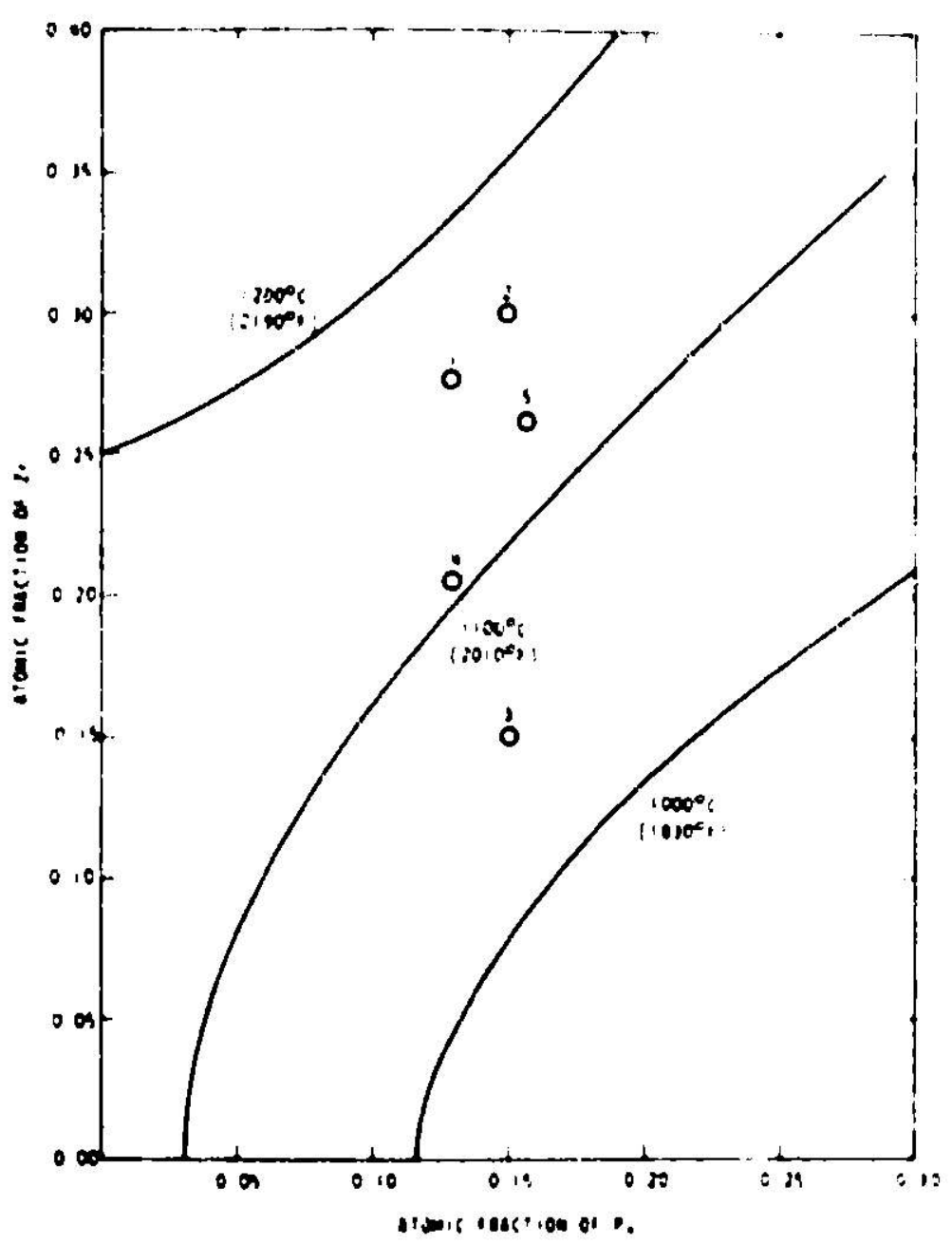

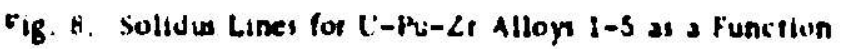
of Atomic fiactions if Zirconium and Plutunium. (iniall citcles indicate itaning comparitions.) A.VL Nieg. No. 103-98097.

plutonium (ace Table XXIII). At lower fuel-centerline temperaturea (i.e.. at the bottom of the (uel column), the center zone. which is all gammil phase, is noi produced, and the outer and middle zones are wider. Other inratigatorass have no: 9 the same diffusion phenomenon out-of-pite in an axiai enperature gradient.

\section{B. Fuel Melting}

Table XXIV oummarizes the available information on U-Pu-Z: melting pointe (solidus and liquidus) and compares them with melting points as aher metallic fuelo. The solidus temperatures for the U-Pu-Zr alloye are will! above those for previously considered U-Pu alloye ouch as U-Pu-Fr ast even exceed the roclting point of uranium. The U-15 wt \% Pu-10 we $\%$ Zr alle, hae - colidus temperature of $-211 C^{\circ} \mathrm{F}$, more than $250^{\circ} \mathrm{F}$ bove the solidus tenterature of U-5 wt $\%$ F. (the EBR-II driver fuel). The U-Fu-Ti alloys alco hore high solidus temperatures, but are not coinpatible with etainless eteels ab. re $-1300^{\circ} \mathrm{F}$. 
TABLE XXIV. Melting Points of Metallac Euels

\begin{tabular}{|c|c|c|}
\hline \multirow[b]{2}{*}{ Fuel Alloy, we \% } & \multicolumn{2}{|c|}{ Melting Point, 'F } \\
\hline & Solidus & Liqiadu* \\
\hline$\because \cdot 1111+u-6.32 r^{2 s}$ & -2050 & -2140 \\
\hline $\mathrm{l}=15 \mathrm{pl}-6.8 \mathrm{kr}$ & $2020 \div 20$ & $2260 \div+0$ \\
\hline $1-151 u_{u}-10 \% \mathrm{r}^{25}$ & -2110 & -2280 \\
\hline $\mathrm{l}=15 \mathrm{Pu}-13.5 \mathrm{Zr}^{3 \mathrm{~s}}$ & $2180 \cdot 20$ & $2600:+10$ \\
\hline $\mathrm{L}-18.5 \mathrm{Pu}-14.12 \mathrm{r}^{25}$ & $21+0$ & -2350 \\
\hline$U-15 P u-10 T_{1}^{23}$ & -2190 & $\cdot 2+t 0$ \\
\hline $\mathrm{L}-5 \mathrm{ks} \mathrm{s}^{16}$ & $1836: 10$ & $1978=10$ \\
\hline$\left(i=15 \mathrm{P} \quad J \mathrm{Fx}^{23}\right.$ & -1590 & -1830 \\
\hline Lranium (unalloyed)"7 & $2070: 2$ & $2070 \cdot ?$ \\
\hline Plutonium (unalloyed) & $1185: 5$ & $1185: 5$ \\
\hline
\end{tabular}

A. Was shown in Fig. 8 . The rolidus temperature of the L-Hu- Z.r systom inc reases with inc reasing zirconium content for the erenary compicitonn considered in this report. As can be seen. the weight perciest involved irannlate into rather high atomic percents. Therefore, sume work should br cton. to optimize the initial zirconiun content of the alloy (1. e. miamizing sirionius. content while relaining acceptably high solidus temperatures and good onipatibility with stainlexs secll

The effect of fission-product busldup during irgadiation on the L-P11-7.s solidus temperature has not been inveutigaled. but on the basis of data on

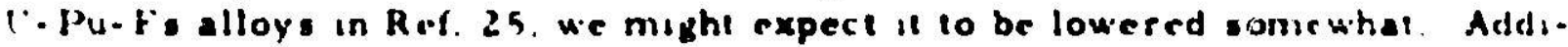
lional elfort is required with regard to this aspect of melting.

\section{Fuel Slumping}

Shortening of (ucl by ireep under ito own weight (elumping) has been of iraditional interest in melallic fuel. Some oul-of-reactor information has bs:en generated on coinpreseive creep of U-18.5 wi 5 Pu-14.1 we $2 \mathrm{Z}$ in the $1100-1300^{\circ} \mathrm{F}$ iemperature rates 23 Based upon solidus temperature. the crecp of U-15 wi : Pll-10 wt $\mathrm{Zr}$ would probably be elightly higher. Figure 9 uer. this data to extrapalate the time for the former fuel composition to tompres. sively crecp (olump) 1t a 1300, 1500, 1700. and 1900\% F. For the sasurnd 36-in.-long fuel pin. the streas is 20 pai at the bottom of the pin (where the temperature is loweet). 10 pei at the coremidplace. and 5 pai one-quarter of the way down from the top of the pin (where the luel iemperature appronches its higheot value)

For an anoumed conervatively high mean tuel temperature (t.e.. 0.5 (fuel-eurface temperature fuel-centerline temperalure al high burnup)] of about $1700^{\circ} \mathrm{F}$ at the top of the pin. $1500^{\circ} \mathrm{F}$ at the core midplane. and $1300^{\circ} \mathrm{F}$ at 


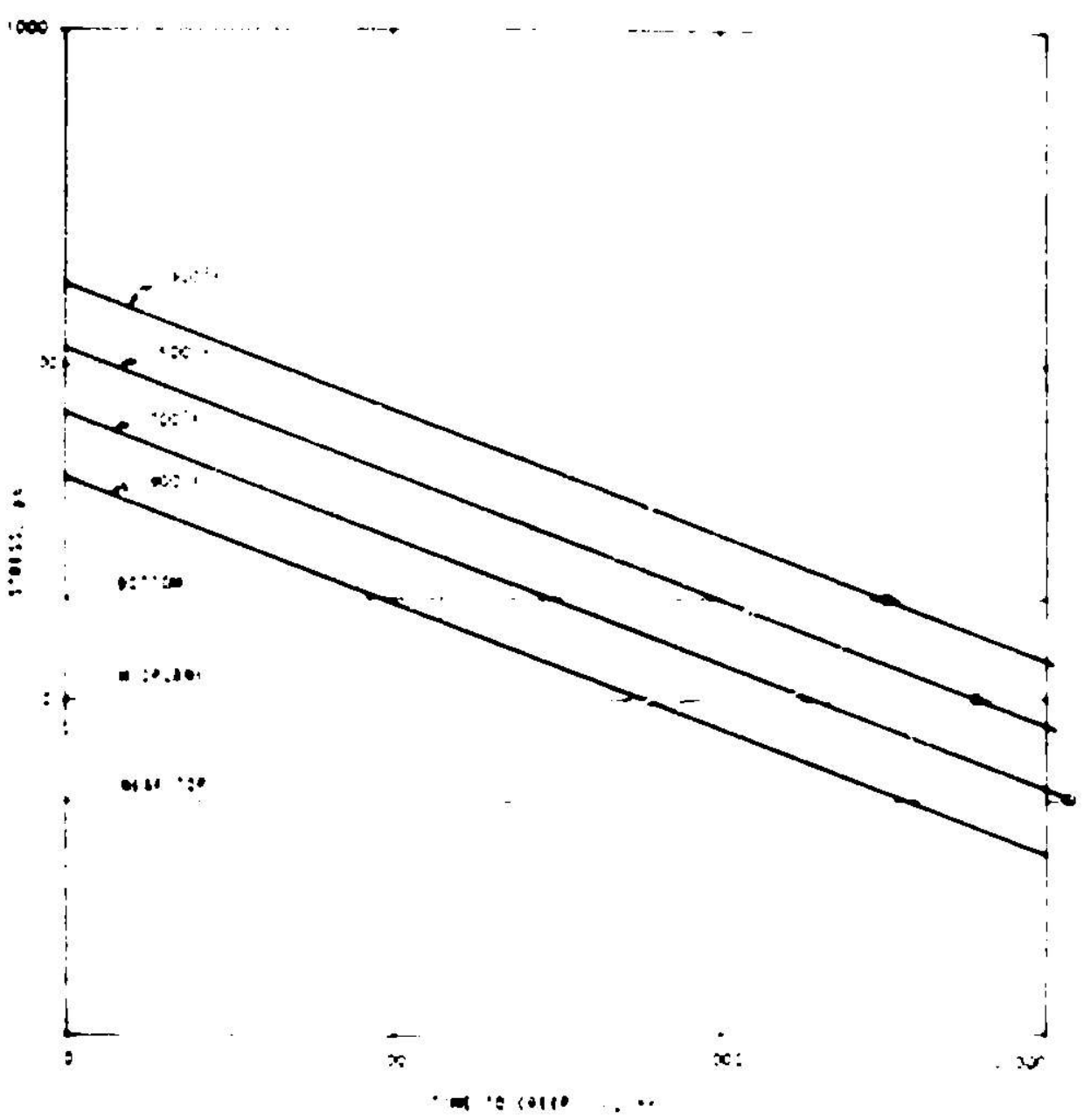

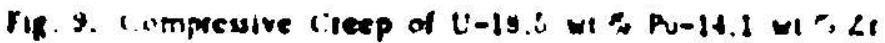

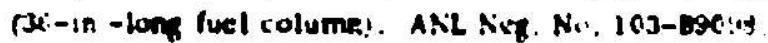

the bottom of the pin. the time to compreanively creep $1 \%$ at the various locations in tre pin is represented by the emall circles in Fig. 9. Overall pin shortening is an integral of these values, wo that $1 \%$ slumping might be expected to occt: : in aboul $6000 \mathrm{hr}$ (250 days). This is about a facing of 10 lese than the normal lengthenine expected due to fuel ewelling during this irradiation period. In other worde. Although irradiation may increave the slur ping rate somewhat, fuel elumpine does not appear to be of any significant conc arn. It has been shown experimentally that, at the fuel-oweiline values obtaired ai high burnup. interconnection of swelline porosity occure accompanied by sodium inflitration and a sienificant increase in thermal conductivity. Therefore, the temperaturee used here certuinly repreaent an overestimate of fuel-centerline temperature.

A note is in order on the method's used to generate Fig. 9. The data were enerated at etrese levele more then a factor of 10 greater then those that interest ue. lor thort timos ( $<100 \mathrm{~min}$ ). ald over a narrow temperature range $\left(1250-1300^{\circ} \mathrm{F}\right)$. Thereinre, the extrapolations to generate Fig. 9 are lerge. 
Thesc extrapolations were performed using conventional high-temperature creep relationships $\left[(\text { time to } 1 \% \text { creep })^{-1}=(\right.$ constant $) \sigma^{n}$ ex:p $\left.(-Q / R T)\right]$ and ohould be appropriate for the temperatures of interest.

D. Conclusions on Thermal Performance

1. Out-of-reactor results indicate that $\mathrm{U}-15$ wt $\% \mathrm{Pu}-10$ wt $\% \mathrm{Zr}$ is compatible (i.e., has an acceptable cladding-ponetration rate and no eutectic formation) with SA 304 stainless steel and a number of high-strength advanced base alloys to temperatures approaching $1500^{\circ} \mathrm{F}$. Information needs to be generated on use of $\mathrm{U}-15$ wt \% Pu- 10 wt \% $\mathrm{Zr}$ with Type 316 stainless steel. Oxygen content of the fuel and cladding may have some effect on compaibility and requires further investigaticn.

2. In-reactor results to 4.5 at. \% burnup indicate that $U-15 w t \%$ Fu- 10 wt \% Zr 18 compatible with SA 316 stainles steel (i.e., has an acceptable cladding-penetration rate and no eutectic formation) at $1200^{\circ} \mathrm{F}$. Irradiations at higher temperature and to greater burnups need to be conducted to define time-temperature limits.

3. In-reactor results to 4.5 at. \% burnup indicate that, at $1200^{\circ} \mathrm{F}$. U. 15 wt \% Pu- 10 wt \% $\mathrm{Zr}$ penetrates SA 304 stainles oteel at about five times the rate it penetrates SA 316 stainless steel. This observation is inconsistent with out-of-reactor results on other fuel systems and requires further investigation via 15 radiation tests. The difference may be due co facrors othe: than the inherent difference between the two stainless steels le.g.. oxygen content of the cladding).

4. Future compatibility tests and irradiatiora should factor in the presence of fission products consistent with the level exper ted with high burnup and fuel reprocessing.

5. The solidus of U-15 wt \% Pu-10 wt \% Zr alloy is sufficiently high $\left(-2100^{\circ} \mathrm{F}\right)$ that fuel melting $c$ an be easily avoidud during normal reactor operation, even assuming rather high codium outlet iemperatures. The effect of fisaion-product buildup (particularly fissium e'emente) on the fuel solidus temperature should be determined.

6. Although data on fuel elumping are ocarce. alumping under normal operating conditions (and probably even severe iransients to near the fuel -olidus temperature) appenre to be of no eignifi:ant concern.

7. The adequacy of Type 316 tainlese steel cladding (cold-worked or annealed) and advanced alloys to contain U-Pu- $\mathrm{Zr}_{\mathrm{r}}$ fuel with acceptable cladding distortions at high burnup $(-10$ at. $\%) \mathrm{can}$ be demonetrated only by additional fuel-element ir radiations. 
The ease oi fabrication of a given fuel design is an important factor in defermining the practical applicability of that design to future LMFBR's. Fuelsabrication processes must be available for both initial core loading and recycled fuel. This section of our report summarizes the fabrication processes used on U-Fs EBR-II fuels and includes the results obtained with the se processes. 't also summarizes the available information on U-Pu-Zr fabrication.

For U-Fs fuel, the same basic processes were used for fabrication of unirradiated fuel and for remote refabrication of irradiated fuel. These same basic processes can probably be used on unirradiated and irradiated U-Pu-Z,r alloys; however, some alternative approaches will also be discussed for $U-P u-Z r$.

\section{A. Fabrication of U-5 wt \% Fs EBR-II Fuels}

A nowsheet for the fabrication of irradiated $2 \mathrm{r}$ unirradiated $\mathrm{U}-\mathrm{Fs}$ EBR-II fuel is shown in Fig. 10. An inert-atmosphere, shielded alpha-gamma cell is used only for processing and fabrication of irradiated fuels that have experienced a low fission-product-decontamination factor (i.e., fuels from which fission products have not been completely removed). Although the processes used for fabrication of unirradiated ${ }^{40,41}$ and irradiated ${ }^{42}$ EBR-II fuels are well documented, we will briefly summarize them.

For unirradiated fuel, an alloy billet is prepared by direct melting of uranium with molybdenum, ruthenium, rhodium, palladium, niobium, zirconium, and silicon alloying elements in a sabilized zirconia crucible at $-3500^{\circ} \mathrm{F}$ for about $2 \mathrm{hr}$ and casting in a $\mathrm{graphite}$ mold coated with zirconia, yttria, or thoria. For ir radiated fuel, the alloy billet results from the melt-refining step (see Sec. VII.A). For either process, the billet is then charged into a graphite crucible cnated with zirconia, yttria, or thoria in the injection-casting furnace. The injection-casting furnace consists of a vacuum-preasure chaniber in which a number of precisicn-bore mold tubes are suspended vertically, open end down, above the crucible in which the fuel is melted. The furnace and the molds are evacuated during the melting cycle. The molds are lowered to immerse the mold ends, and the furnace is rapidly pressurized with inert gas. The pressure on the surface of the metal in the crucible caupes the evacuated molds to fill. As soon as the metal in the molds solidifies, the molds are raised.

High-silica glass is used as the mold material because it can be formed to satisfactory tolerances and it withstands the thermal shock of casting at $-2550^{\circ} \mathrm{F}$. One end of the mold tube is flattened and fused closed; the opposite end is cut at a $60^{\circ}$ angle to the axis to aid in penetrating the melt surface and to allow excese metal to drip from the end of the mold. Reaction between the sllica and the fuel alloy is prevented by a thin coating of zirconia, thoria, or yttria. Experience with th.e F.BR-II injection-casting furnaces, esch of which melts $10-17 \mathrm{~kg}$ of alloy and casts as many as 160 fuel pins at s time, indicates 


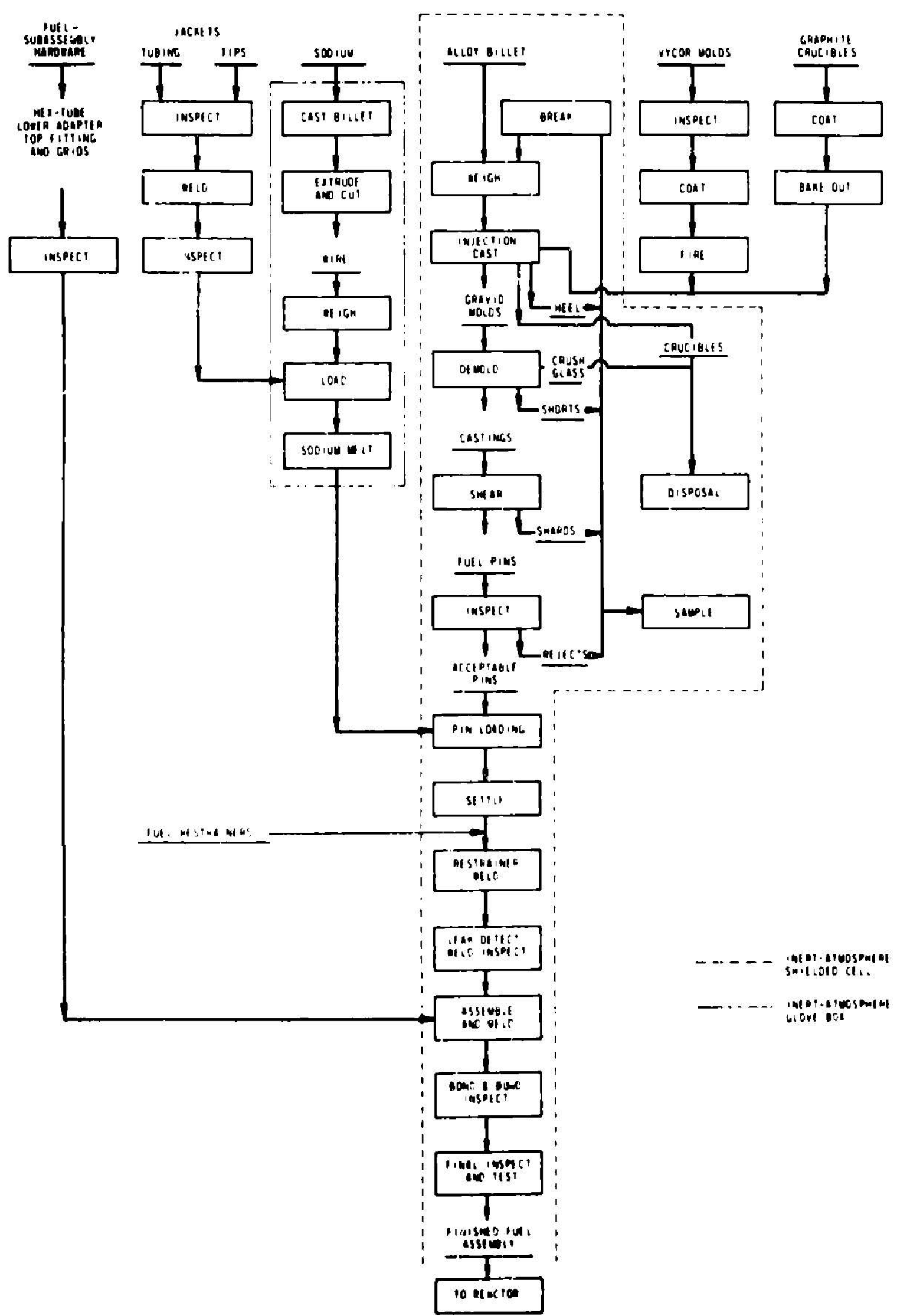

Fig. 1C. Fabrication Scheme for Melallic Fuel. ANL Neg. No. 103-89096. 
that the equipment can be scaled up to melt $70-\mathrm{kg}$ charges to cast about 350 pins at a time. Pressurized inert gas is circulated between the molds for rapid cooling.

A residual heel amounting to about $20 \%$ of the charge weight is left be hind after casting. This heel is usually removed from the crucible after solidification, broken, and recharged into succeeding melts without significant loss.

Demolding is accomplished by crushing the glass away from the fuel pin. The fuel pins are deliberately cast overlength, and segments are cropped from the top and bottom by shearing. The end shards are collected and returned either to the melt-refining or the injection-casting operation. No further mechanical work is required to finish the fuel pins. The pins are inspected for weight, length, diameter, and porosity using automated inspection equipment.

High-purity sodium to thermally bond the pin to the jacket is loaded as a solid wire segment into the previously fabricated jackets. After sodiumloading, the fuel pins are inserted into the jackets, and an end plug is welded in place using capacitive-discharge techniques. The plug-to-jacket weld is leak-tested by a pressure-decay method, and the elements are then ready for the sodium-bonding operation. Sodium-bonding is effected by heating the fuel elements to $\sim 950^{\circ} \mathrm{F}$, holding for about $1 \mathrm{hr}$, and impacting -1000 times.

Final element inspection includes eddy-current interrogation for sodium-bond quality and sodium level, visual examisation for hardling damage, and dimensional checks.

Table XXV summarizes the types and quantities of EBR-II U-Fs iuel elements produced as of June 1975 by the basic processes described above. It also differentiates tetween fabrication of unirradiated fuel and refabrication of irradiated fuel. Well over 100,000 metallic EBR-II fuel elements have been manufactured from both irradiated and unirradiated material in essentially pilot-plant manufacturing facilities. Only one failure of a U-Fs fuel element during the $10 \mathrm{yr}$ of EBR-II operating experience was traceable to a fuel-element manufacturing defec:. This one failure was due to a faulty lower weld in a Mark-IA element.

TABLE XXV. EBR-II U-5 wt \% Fs Fuel Elements Produced as of June 1975

\begin{tabular}{ccc}
\hline \multicolumn{1}{c}{ Fuel Deaign } & Unirradiated & Irradiated \\
\hline Mark I and Mark IA & 59.000 & 35,000 \\
Mark II & 22.000 & 0 \\
\hline
\end{tabular}


B. Fabrication of U-Pu-Z.r Fuels

Injection casting appears to be a feasible approach to fabricating $\mathrm{U}-\mathrm{Pu}$ $\mathrm{Zr}$ alloys, although other processes (e.g., extrusion) should also be considered. Srnall numbers $(\sim 50)$ of U-Pu-Zr fuel pins have been rnanufactured by injection casting for the experimental irradiations described previously. If the injectioncasting process is assumed applicable, then the fowsheet used for U-Fs alloys (Fig. 10) can be used without change. It is appropriate, however, to examine fabrication processes within this flowsheet that would have to be modified from those used for $\mathrm{U}-\mathrm{F}_{\mathrm{s}}$. Although not much work has been done on $\mathrm{U}-\mathrm{Pu}-\mathrm{Zr}$, the principal problems appear to be associated with obtaining homogeneous alloy billets and cast fuel pins.

\section{Preparation of Homogeneous Alloy Billets}

Workers at LA.SL have had considerable success in preparing homogeneous cast billets by mechanical stirring of the melt and bottom-pour chill casting. ${ }^{35}$ Two ceramic crucible coating s that could be applied to standard bottom-pour graphite crucibles were developed so that conventional alloying and casting techniques could be used. The coating more inert to the U-Pu-Zr alloys was NbC applied directly to the graphite surface. The amount of niobium dissolved into the melt was reported to be less than $25 \mathrm{ppm}$, and the oxygen pickup was negligible. The second coating, a $\mathrm{Y}_{2} \mathrm{O}_{3}$ coating codeveloped by LASL and Acheson Colloids Company, consistel of a water suspension of $\mathrm{Y}_{2} \mathrm{O}_{3}$ with a $\mathrm{K}_{2} \mathrm{SiO}_{3}$ binder added. When properly applied, this coating was unwetted by the $U-P u-Z r$ melt, and the graphite crucible could be reused. Alloy billets prepared in $\mathrm{Y}_{2} \mathrm{O}_{3}$-coated crucibles picked up about $100 \mathrm{ppm}$ of both ilicon and oxygen.

Alloying was accomplished by inductively co-melting the metals (uranium, plutonium, and zirconium) under vacuum in the coated $g$ raphite crucible. The molten metals were heated to $2550-2700^{\circ} \mathrm{F}$ and mechanically stirred for $30 \mathrm{~min}$ to ensure dissolution of zirconium into the melt. The stopper rod was raised, and the melt was chill-cast into an aluminum mold at ambient temperature. Table XXV! summarizes the chemical analysis of some of these cast alloys. This approach was effective in minimizing axial variations in zirconium content; however, as is typical for inverse segregation, the variations in radial composition were as great as 0.8 wt \% $\mathrm{Zr}$.

TABLE XXVI Chemical Analyeis of Chill-cael U-Pu-Zr Alloys"

\begin{tabular}{|c|c|c|c|c|c|c|}
\hline \multirow[b]{2}{*}{ Element } & \multicolumn{6}{|c|}{ Composition, wit } \\
\hline & Top & Bottom & Top & Bottom & Top & Bottons \\
\hline$z r$ & $6.8-7.4$ & $6.6-7.0$ & $10.1 \cdot 10 . t$ & $9.9 \cdot 10.2$ & $13.3-14.1$ & $13 . t-13.6$ \\
\hline$P_{u}$ & $1+.8$ & $1+.9$ & 15.2 & 15.1 & 14.6 & 14.6 \\
\hline 11 & $7 k .1$ & 77.9 & 75.4 & 74.7 & 72.3 & 72.0 \\
\hline
\end{tabular}


Alloy preparation at ANL was less successful without mechanical stirring and required extensive use of master alloys to get zirconium into solution at temperatures low enough to prevent unacceptable reaction of the melt with the crucibles. 43

\section{Injec! on Casting}

ANL workers experienced some difficulty in injection-casting U-Pu-Zr alloys. ${ }^{13}$ This difficulty was in large part due to the rather nigh injection-casting melt temperatures required. e.g.. $-2800^{\circ} F$ for $U-15$ wt \% Pu14 wt $\% \mathrm{Zr}$. This temperature approaches the softening temperature of the Vycor casting molds. Because U-15 wt \% Pu-10 wt \% Zr has a lower liquidus temperature and some adjustment in casting parameters is feasible, it shnuld be possible to injection cast at somewhat lower melt temperatures. Nevertheless, the ANL workers were able to successfully cast $0.1+4$ - and 0.166 -in.-dia fuel pins with acceptable homogeneity in up to 13 -in. lengths, using $\mathrm{U}-15 \mathrm{wt} \% \mathrm{Pu}-14$ wt $\% \mathrm{Zr}$ and $\mathrm{U}-15$ wt $\% \mathrm{Pu}-10$ we $\% \mathrm{Zr}$. It appears that, with some additional fabrication development work (perhapg ining the LASL billetpreparation technique, together with a refinement of the ANL injection-casting technique), the process outlined in Fig. 10 could te applied to both irradiated and unirradiated $U-P u-7 . r$ alloys.

\section{Alternative Processes for Fucl-pin Fabrication}

Even though injection casting of $\mathrm{U}-\mathrm{Pu}-\mathrm{Zr}$ has been demonstrated on a small scale, other pin-forming processes should not be overlooked. LASL has done some development on extrusion and swaging of $U-P u-Z r$ into fuel pins." Of these two techniques. extrusion showed by far the greatest promise. LASL's studics indicated that bare extrusion at $-1000^{\circ} \mathrm{F}$ of 0.75 -in.-dia chillcast billets down to $0.1+f-i n$ - dia fuel pins with a $100-10150-t o n$ press shculd present no particular difficulty. The pr: em with this approach is twofold. however.

a. The remote operation and maintenance of an extrusion press in a hot-cell environment for refabricating irradiated fuels will be difficult at best.

b. Considerable effort would be required to determine whether w uch fuel could be properly heat-treated to remove fabrication-induced texture (prcferred orientation). Very small degrees of preferred orientation have been shown to result in rather substantial ir radiation growth in metallic fastreactor fuel. 14

One linal obvious difference exists between fabricating U-Fs and U-Pu-Zr alloy. (irradiated or unlrradiated): the requirement for adequate containment of plutontum to protect personnel. 
C. Conclusions on Fabricability

1. Based upon experienre with EBR-II U-F. fuels, an extension of exioting technology to the fabrication of irradiated and unirradiated $\mathrm{U}-\mathrm{Pu}-\mathrm{Zr}$ alloys dues appear teasible.

2. Such an extension in technology would require additional development studies on producing homogeneous $U-P_{u}-Z_{r}$ fuel alloys and acceptable injection-casting yields in quantities consistent with the fuel needs of a reactor.

3. The feasibility of extrusion or other alternative pin-fabrication methods for producing large quantities in a remote-refabrication facility should be evaluated. If one or more of the methods seem feasible, development studies on the fabrication and the heat treatment to eliminate texture would be required. 


\section{FUEL REPROCESSING}

Before a fuel becomes a serious contender for the LMFBR program, a high degree of confidence must exist that it can be reprocessed in a practical and economical manner. Without a good fuel-reprocessing scheme, much of the justification for breeders is lost.

This section of our report briefly (1) describes past ANL experience with reprocessing irradiated stainless steel-clad U-5 wt \% Fs EBR-II driver fuel and (2) nnsiders the feasibility of future reprocessing of irradiated U$\mathrm{Pu}-\mathrm{Zr}$ fueis clad in stainless steel. Our discussions consider remote pyrochemical (pyrometallurgical) and solvent-extraction reprocessing as well as remote refabrication of irradiated fuels in a facility closely coupled with a reactor(s). The advantages of this close coupling are: (1) short cooling periods that allow for rapid return of fuel to the reactor (an especially important consideration in breeder reactors), and (2) greatly reduced need for off-site shipping of special nuclear materials and radioactive waste products.

\section{A. Reprocessing of U-5 wt \% Fs EBR-II Driver Fuel}

The developmeit and application of remote pyrochemical (pyrometallurgical) reprocessing and remote refabrication of U-5 wt \% Fs EBR-II driver fuel are well-documented. ${ }^{42,45,46}$ The reprocessing begins about 14 days following a reactor shutdown and consists of the following steps: (1) transfer of the $91-e)$ ment subassemblies to the reprocessing facility, (2) disassembly of the subassemblies into individual elements, (3) mechanical decladding of the elernents, and (4) chopping of the deciad fuel pins for charging into the limestabilized zirconia melt-refining crucible.

Melt refining (see Fig. 11) is conducted at $-2550^{\circ} \mathrm{F}$ for $1-3 \mathrm{hr}$, after which the refined rnelt is chill-cast into a mold. During the melt-refining step, electropositive fission products (mainly alkaline-earth and rare-earth fission products) react with the zirconia crucible to form oxides, which deposit along the wetted crucible surfaces. The fission-product gases (xenon and krypton) are released to the furnace, from which they are pumped (through a charcoal trap that removes traces of iodine) to a large tank where they are stored. Condensable fission products (moinly cesium and iodine) are collected within the furnace on a Fiberfrax fume trap above the crucible.

The refined ingot, containing molybdenum, ruthenium, rhodium, palladiurn, niobium, technetium, and zirconium fission products (fissium), is removed fr.m the mold and formed into new fuel pins by injection casting, a process in which the molten fuel is forced by gas pressure into precieionbore Vycor tubes. Following injection casting, the new fuel pins are cut to length, inspected, and inserted into stainless steel jackets together with a sufficient amount of sodium to bond the pins to the cladding. The fuel elements (jackets plus pins) are then seal-welded closed, leak-checked, bonded, inspected, and reassembled into 91 -element subassemblies. The new subassemblies are then transferred baci to the reactor for irradiation. 
APPROXIMATE DISTRIBUTION OF ELEMENTS IN MELT-REFINING PROCESS

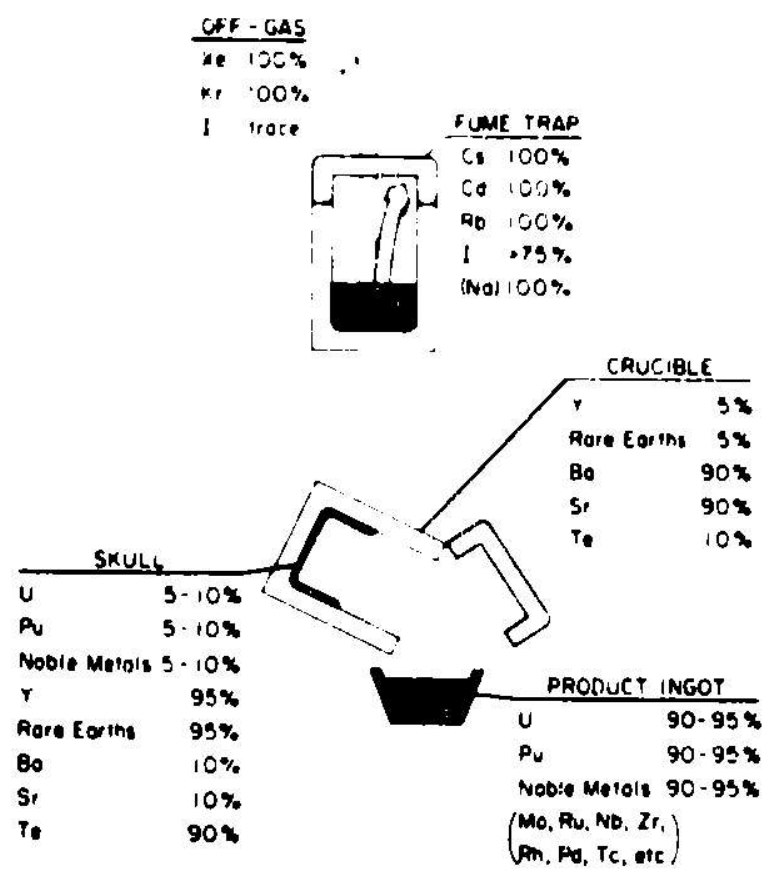

Fib. 11. Fission-ptoduct Removal in Melt Refining of EBR-Il (1-Fs Fuel. ANL Neg. No. 103-B90:1.
The entire reprocessing and refabrication process is performed remotely and has been routinely accomplished in 45 days or less in the EBR-II Fuel Cycle Facility. This facility is close-coupled to the EBR-II reactor, and during $1964-1969$ produced 35,000 reprocessed and refabricated fuel elements for the reactor. In 1969, the mission of the EBR-II reactor was changed from a prototype demonstration reactor with closed-rycle fuel reprocessing to a fast-neutron irradiation test facility. This change in mission for the reactor dictated a mission change for the Fuel Cycle Facility to an examination facility for experiments irradiated in EBR-II.

Molybdenum, ruthenium, rhodium, palladium, niobium, and technetium are not removed during melt refining, and zirconium is only partially removed. The aggregate of these elements (fissium) therefore increases in the refined material at the rate of about $0.35 \mathrm{wt} \%$ Fs per at. $\%$ burnup. This buildup in fissium content is controlled by a side stream called "dragout." Suppose a fuel initially containing $5 \mathrm{wt} \% \mathrm{Fs}$ is irradiated to 1 at. \% burnup. The fissium content would then increase to 5.35 wt \% Fs, about a $7 \%$ increase. Simply stated for this example, dragout is the intentional side streaming of $7 \%$ of the refined material to another process for quantitative removal of fissium elements. Uranium with the proper enrichment is then added to the remaining $93 \%$ to bring the refined ingot up to $100 \%$ of its original weight, resulting in an adjusted fissium composition of 5 wt \% Fs.

In actual practice, the melt-refining step results in an ingot plus a skull (oxidized dross and some unpoured metal) whish remains in the zirconia crucible. This skull accounted for 5-10\% of the $\mathrm{n}$ elt-refining charge, so no additional dragout was required for fuels having 12 at. \% burnup.

Before discussing the process used for reclamation of skulls, we need to consider the effects of burnups above 2 at. $\%$ on the dragout requirements. First, assume a 0.35 wt \% Fs increase per at. \% burnup and a desirable 5 wt $\%$ Fs content at the beginning of each burnup cycle. Further assume a burnup limit of 10 at. \%, which seems to be a reasonable goal based upon results of irradiating EBR-II Mark-Il fuel. At 10 at. \% burnup, the fissium content will increase 
from 5 to $8.5 \mathrm{wt} \%$ (i.e., a $70 \%$ increase in fissium content). Therefore, as a first approximation, $70 \%$ dragout is required. The implications of this are important; even if the desired starting fissium content is increased 1010 wt $\% \mathrm{Fs}$, $35 \%$ dragout is required. Therefore, either tivo major processes (melt refining and dragout refining) are required to reprocess high-burnup U-Fs fuels, or a single process must be developed to remove the fissium elements.

A skull-reclamation process for EBR-II U-Fs fuel (see Fig. 12) was developed and tested on a pilot $3 \mathrm{cale},{ }^{47}$ but was never installed and made operational in the EBR-II Fuel Cycle Facility. In the process, liquid-metal and molten-salt media are used, and solubility differences and selective oxicationreduction reactions are applied to make possible the necessary separations of uranium from the fissium elements. The solvent-metal phases are zincmagnesium alloys, and the salt phase is a mixture of alkaline-earth halides $\left(47.5 \mathrm{~mol} \% \mathrm{MgCl}_{2}, 47.5 \mathrm{~mol} \% \mathrm{CaCl}_{2}\right.$, and $5.0 \mathrm{~mol} \% \mathrm{MgF}_{2}$ or $\mathrm{CaF}_{2}$ ). This approach was established to process skulls from low-burnup fuel, which accounts for $5-10 \%$ of the melt-refining charges. Its applicability to 35 or $70 \%$ dragout on high-burnup fuels appears impraztical, because the equipment and the quantity of process wastes become prohibitively large. In addition, it is limited to uranium fuels, since it is incapable of separating plutonium from rare earths. This separation would be requireo for plutonium-bearing fuels such as $U-P u-Z r$.

As an alternative, a combination of melt-refining and solvent-extraction proce 3 ses could have significant advantages. The melt-refining step would then serve as a head-end step for the subsequent solvent-extraction process. Thus. about half the spent fuel would be available for immediate recycling (after suit able alloy adjustment). The melting operation would also serve to remove fission-product gases (xenon, krypton, and tritium) and volatile fission products (cesium and iodine) from the half of the fuel that goes to solvent extraction. (These fission products are a major problem in the application of solvent extraction to reprocessing of any kind of high-burnup, sliort-cooled fuel.) An additional benefit would be a reduction in gross beta-gamma activity, which contributes to solvent damage.

\section{B. Reprocessing of U-Pu-Zr Fuels}

We are not aware of any information on the reprocessing and refabrication of $\mathrm{U}-\mathrm{Pu}-\mathrm{Zr}$ alloys. However, preliminary studies have been conducted on pyrochemical reprocessing of U-Pu-Ti fuels. ${ }^{40}$ A process similar to that suggested for $\mathrm{U}-\mathrm{Pu}-\mathrm{Ti}$ would be appropriate for U-Pu-Zx. Figure 13 presents a flowsheet for reprocessing U-Pu-Ti fuel together with a uranium blanket. This process resembles that used successfully for EBR-II U-Fs fuel in that it refines irradiated fuel by use of melting, molten-salt media, and solvent-metal phases. The flowsheet does not represent the only selertion of pyrochemical steps that would satisfy the processing requirements. Alternative process steps require study, irowever, but some of them are expected to lead to more economical processing. The flowsheet of Fig. 13 was chosen for U-Pu-Ti 


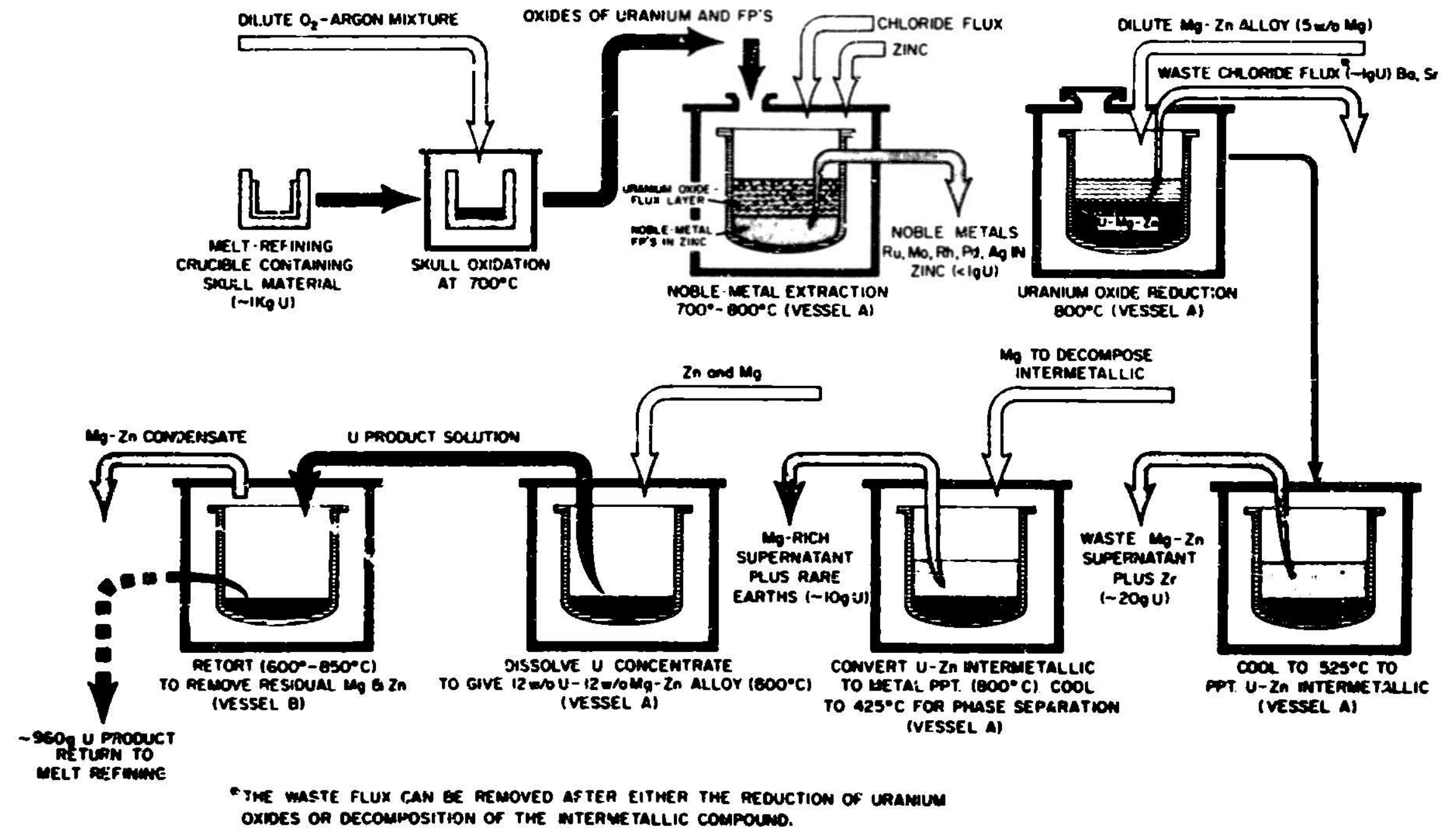

Fig. 12. ERR-Il Liquid-metai Process for Reclomation of Melt-tefining Sku!ls. ANI. Neg. No. 103-B9075. 


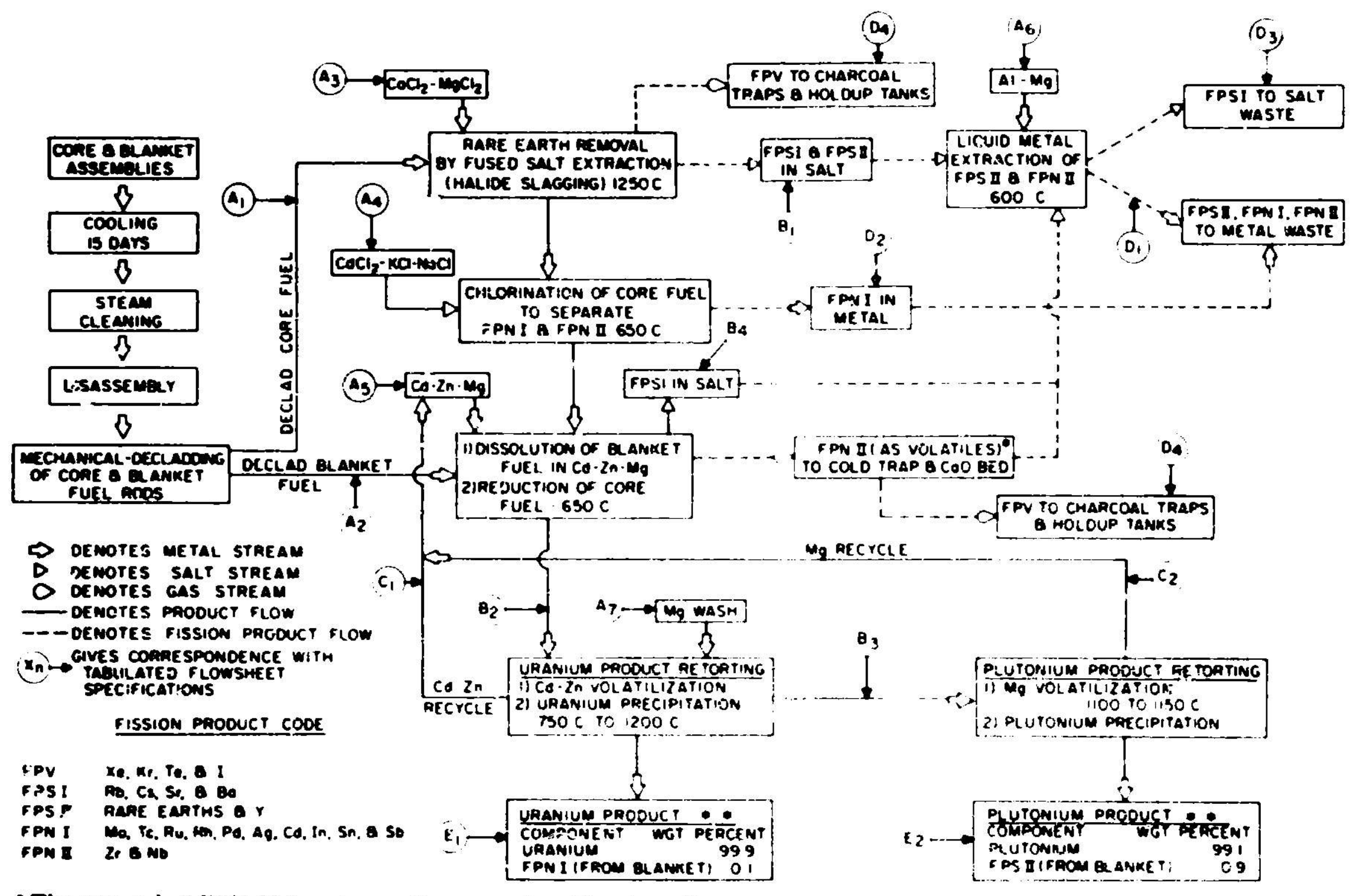

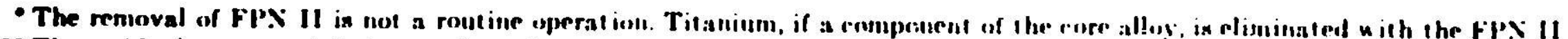
fuel.

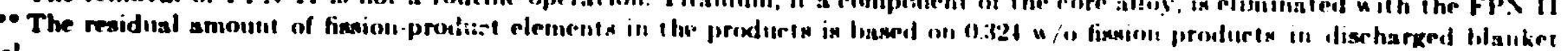

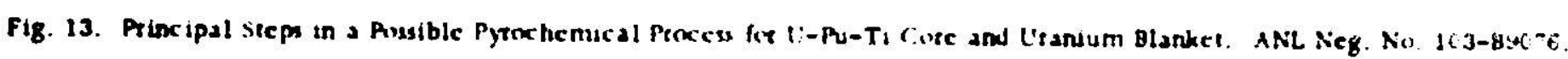


because it carsists of an asacmblage of pyrochemscal serpe for which (1) nutficient suppor! is available from laboratory and pilot-plant studies to provide nome degree of contidence in the technical ixasibility of the steps. and (2) suffic ient information is avalable from component-developmen! stidies to develep conceptual equipment designs.

Althesgh differences in fabricability exist botween $U-F$ and $i-P_{0}-Z_{r}$

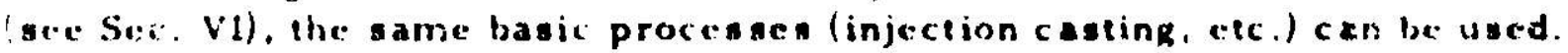
Therefore, the information already preacuted on refabrication of $L-F$ s fuels is alao applicable to U-Pu-\%.r furls.

An alternative approach to reprocesoing U-Pu-Zr fuele is the Purex solvent-cextraction process. That process has long and extensive hintory in reprocessing a broad range of reactor fuele"t, 30 and is currently being studied with the objective of adapting it to fast-reactor tuele. It is anticipated that some unique problems may be associatcd with dissolution of the ainy to prepare feed solution. For exainple, there is evidence that uranium-zirconium alloys may react explosively with nitric acid." The eame hazard may exisi with $l:-l,-Z r-F s$ alloyn. Oxidizing the alloy before diseolution may eliminate that hatard. Ilowever, dis solution of solid-solution (U-Pu-Zr) oxide may be difficult and may require the use of hydrofluoric acid. The problen of alloy disalution would require conaiderable investigation. Criticality hazarda with respect in the dissolver. leed-adjustment sanks, and contacting equipment would have in be resolved.

The Purex process produces uranium and plutonium nitraten essen!jelly fr... of all fission products. Reconversion to the metals is a well-established procedure. ${ }^{44}$ such clean metals would be well sulted to adjusement of the tis sirim content of the blended metal alloy that is to be returned to fuel fabrication.

A further potential benefit may be derived fron ihe combined system of melt-re-Sining and Purex reprocessing. Since about hall the fuel in completely purified. it may not be necessary to remove the alkaline- and rare-earth fission products from the portion that it recycled direct!y to refobrication. It would then be poseible to eliminate the 1-3-hr liquation at $2550^{\circ} \mathrm{F}$. Li may also be possible to subetifue another crucible material for the coetly zieconia crucible. which cannot be reused. Thus, perhape a graphite cruciblecculd be used tor effecting a rapid nitii of the chopped fuel. followed by pouring the double ingot.

If these modifications of the melt-refining step are practical, it showld be posatble to aignifi:antly reduce the operating time for this step. Thus, two or three melting operations could be performed in the same furnace during a 24-hr day. A single 1000-MWe LMFBR would require a fuel-reprocssefing rate of about $70 \mathrm{~kg}$ of fuel per day. If a critically eafe furnace can handie $20 \mathrm{~kg}$ in a angle melt, two furnaccs siould be bufficient for reprocesing the fuel from a 1000-MWr reactor. Increasing the size of the facility to handle fuel froin three close-coupled plants thould be teastble. 
Since a Purex plane in be desikned to handle several tonres of reactes fuel per day, a single Purex pla $^{\text {a }}$ could handle the draxout from several me!t-

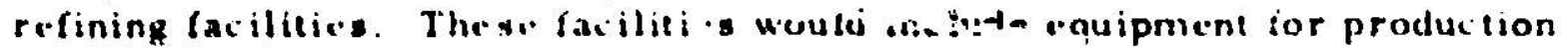
of uranium and plutonium metals from the Purex plant pruciuct i ent for remote refabrication of fucl clements and fuel subasscmblies. Accurdingly, the overall syetem would be uriquely delap!z!:ti iv a iarge revclor pagk. Such a park would irciude a large numbes of reactors (perhaps a varietv of reactors) and the associated factilities for reprocesaing a.ld reiabricating fuel subassemblies.

Clearly. additional studies are required on processes for refining irradiated $\left[-P_{u}-Z, r\right.$ fuels. However. the hasic technolony associated with all the remote stepn of subassembly tranafer, dinassembiy. pin decladding, melt refining. pin casting. fuel-element refabrication, and subassembiy refobrication have becn demonstrated in the kllk-ll Fuel Cycle Facility for abnut 35,000 fuei elements. The following demonstrations of feasibility already achicved at EBR-Il are particularly important.

1. Removal of gascous and volatile fission products by simply melting the ir radiated fuel. This is very practical for U-Pu-Zr alloy=, which melt at about $2300^{\circ} \mathrm{F}\left(1260^{\circ} \mathrm{C}\right)$.

2. Quick turnaround of refined and refabricaled fuel to the reactor, hecause only minienal cooling time (-1+ day following reartor shutdown) is: required before beginning reprocessing.

3. Ability to remote!y refine, refabricate, and inspect metallic fuels.

1. Ability to remotely maintain reprocessing and refabricating equipment.

5. Ability to design and operate an efficiene, quick-turnaround, on-site reprocessing plant that is scaled in size to match the LMFBR it supports.

6. Demunstration of high reprocessing - and refabricating-facility Ivailability $(-85 \%)$ over an extended perind of time (six years).

The larger subasomblice designed for commercial breeder reactors will require redesign of equipment and operating facilities. The higher burnup enticipated will probably require a longer cooling period (say 30 days). Additional studics will be necessary to etablish optimum conditions for fuel dissolution and other steps, but the fund mental background for each atep justifies an optimistic projection for the overall process. Onc problem, which applies to ell fant-reactor fuel processes. is thi ultimate control and storage of fisaion-product wastea, including fodine and the fission-product gasea.

\section{Conclusione on Reprocenaing}

1. A simple extension of refining procense dereloped and ouccesafully applied on EBK-II U-Fs fuel to the refining of U-Pu-Zr luels does not appear 
feasible. The reasons for this are: (a) the higher burnups and the accompanying high fisaium-element content expected in U-Pu-Zr cannot be controlled with only melt refiniag, and (b) the higher burnups and the presence of plutonium in U-Fu-Zr cannot be accommodated by the EBR-II skull-reclamation process. However, parts of the EBR-II reprocessing scheme are applicable (e.g., melting to remove gaseous and volatile fission products).

2. A simple extension of remote refabrication processes developed and applied on EBR-II U-Fs fuel to the remote refabrication of U-Pu-Zr fuels does appear feasible.

3. The experience gained with remote reprocessing and refabrication of II-Fs fuel elements in the EBR-II Fuel Cycle Facility is invaluable in demonstrating for metallic fuels that (a) alloy fuel can be routinely refined, refabricatcd and returned to the reactor in a relatively short time ( 45 days) following reautnr discharge, (b) complete remote refining and refabrication is a practical approach to fuel recycle, (c) remote maintenance of refining and refabrication equipment $c$ an be performed routinely, and (d) a fucl-reprocessing facility using remote techniques can operate at a high facility availability $(-85 \%)$ over an extended period of time ( $\sim$ ix years).

4. A conioination of melt refining and polvent extraction of highly radioactive fuel in conjunction with remote refabrication appears to offer great advantages to a metallic fuel cycle, including (a) initiation of reprocessing as early as 14 days following reactor shutdown, (b) quick turnaround of external fuel inventory during recycle (i.e., reduced overall inventory), (c) reprocessing at the reactor site in a plant scaled to fit the adjoining LMFBR, and (d) reduc tion in the quantity of fuel that must be subjected to complete aqueous processing and subsequent reduction to metal form. 


\section{SAFETY CONSIDERATIONS}

This section compares safety-related characteristics of large metalfueled LMFBR's with those of corresponding oxide-fueled LMFBR's and then considers how these cha $i$ acteristics affect off-normal reactor operation. The most important safety-related characteristics are fuel-element design, time constants for heat transfer, modes of failure, and mechanisms for feedback reactivity. Off-normal operation includes the two general categories of transient overpower and loss-of-flow malfunctions.

\section{A. Safety-related Characteristics}

Table XXVII lists safety-related parametcrs for a 1000-MWe metalfueled LMFBR and a corresponding oxide-fueled LMFBR. Design information on the metal-fueled reactor was taken from the unpublished parametric stucly done at Argonne National Laboratory in 1967 and discussed in jec. III. A. This reactor had a core height of 38.2 in., a core equivalent diameter of 95.6 in. $(\mathrm{H} / \mathrm{D}=0.40)$, a core volume of 4500 liters, and an average core power density of $500 \mathrm{~kW} /$ liter. Information on the oxide-fueled reactor was taken la rgely from Ref. 51. The core height of this reactor was 36.0 in., its equivalent diameter was $81.8 \mathrm{in}$. $(\mathrm{H} / \mathrm{D}=0.44)$, its volume was 3100 liters, and its average power density was $657 \mathrm{~kW} /$ liter. In both reactors, the sodium-ccolant inlet temperature was $855^{\circ} \mathrm{F}$, and the mixed mean core $\Delta \mathrm{T}$ was $295^{\circ} \mathrm{F}$.

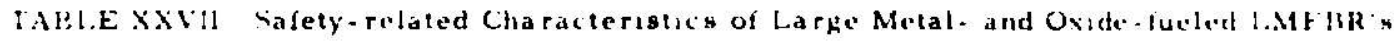

\begin{tabular}{|c|c|c|}
\hline & Martaf-fueled & Oxide- tucled \\
\hline $\begin{array}{l}\text { Fuel material } \\
\text { Clachelums material }\end{array}$ & 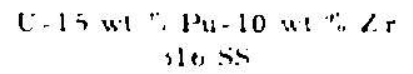 & 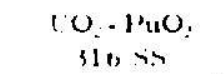 \\
\hline Cladrang OI) $x$ wall thackness. in & $0.212 \times 001$ & $0: 10 \times 0014^{\circ}$ \\
\hline Fuel-pin diameler (as fabruated) in & $111=2$ & 111154 \\
\hline Ihermal-butid material fa, fabrualedt & $\therefore a$ & Hir." \\
\hline Fuel mp solidus liquadur. F & $\therefore 110 \therefore 80$ & $2010>305$ \\
\hline Fuei-ladaing eutectic temp ! & 1515 & Sism. \\
\hline Peah linear puwer." $\mathrm{kW}$ fi & 12.1 & $1+1.1$ \\
\hline Nortual max cladding temp d $t$ & $i$ isto & $1300^{\circ}$ \\
\hline Vurmal max tuel temp ${ }^{d} \mathrm{r}$ & $1+2+$ & +480 \\
\hline I acl-e lement ince constant for heal translet. wee & 01 & 1 \\
\hline 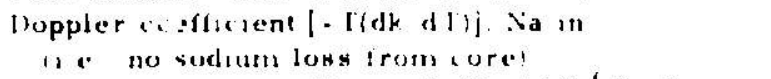 & $.0003^{\prime \prime}$ & $000 x^{2}$ \\
\hline Ixia' expan-lou vefficient |-(dk d I) $\left.\right|^{\prime}$ I I & $\therefore 1 \times 10^{-4}$ & $1101 \times 10^{-}$ \\
\hline
\end{tabular}

atromke1 SI

bror vO -15 al " puO.

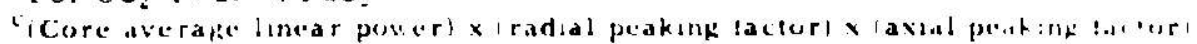

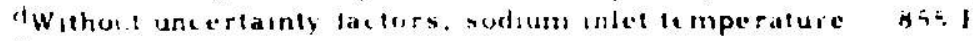

"From Ka.l to

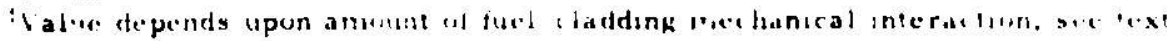

As shown in Table XXVII, the ternary metal fuel allny has a solidus temperature of about $2110^{\circ} \mathrm{F}$ and a liquidus temperature of about $2280^{\circ} \mathrm{F}$. This alloy, however, forms a eutectic with SA 316 stainless steel at about $1515^{n} \mathrm{~F}$. For the U-5 Fs/SA 316 stainless steel fuel element used in EBR-II, the cladding penetration rate becomes significant with respect to reactor-accident 
time scales (i.e., about $5 \%$ cladding-wall penetration $/ \mathrm{min}$ ) at about $1565^{\circ} \mathrm{F}$. On the hasis of discussions in Secs. V.A.I and V.A.3, it is assumed here that this same temperature holds for the ternary alloy. That is, a cladding-inner-wall temperature of $1565^{\circ} \mathrm{F}$ represents a condition of incipient failure for a fuel element of the ternary alloy. This is about $245^{\circ} \mathrm{F}$ above the normal maximum cladding-inner-wall temperature given in Table XXV11. The corresponding increase in average fuel temperature is from about 1196 to $1411^{\circ} \mathrm{F}$.

Another important temperature is that at which sodium boiling occurs: such boiling could lead to overheating of elements and their subsequent failure. Sodium boils at 1640 ' F at an absolute pressure of 1.1 atm. If sodium superheating is neglected and a $\Delta T$ of about $20 \mathrm{~F}$ across the sodium film and of about $30^{\circ} \mathrm{F}$ across the cladding wall at the core top is assumed, sodium boiling would occur when the maximum cladaing. inner-wall temperature is about $1690^{\circ} \mathrm{F}$. This is about $125^{\circ} \mathrm{F}$ above the cladding-inner-wall temperature at which cladding perietration by fuel becomes a safety consern. Thus, for the metal-fuel element, cladding penetration by fuel is taken as the controlling failure mechanism.

The solidus and liquidus temperatures of the mixed-oxide fuel depend upon its composition: for $\mathrm{UO}_{2}-15$ at. $\% \mathrm{PuO}_{2}$. these temperatures are about 5010 and $5050^{\circ} \mathrm{F}$, respectively. The mixed-oxide fuel does not form a eutectic with the cladding. Here, as with the metal-fuel element, overheating due to sodium boiling would be expected at a cladding-inner-wall temperature of about $1690^{\circ} \mathrm{F}$, which is about $390^{\circ} \mathrm{F}$. bove the normal maximum temperature. The corresponding increase in average oxide-fuel temperature in from about 2560 to about $3000^{\circ} \mathrm{F}$.

Inherent negative feedback reactivity acts to increase the time to reach a severe failure condition. It also might act to mitigate the consequences of such failure in the extremely unlikely event of total malfunctioning of the plant protection system. Inherent negative leedback reactivity is provided by material thermal expansion and by the Doppler effect. Material expansion increases neutron leakage from the reactor and moves fuel to positions of lover seactivity worth. Such movement may he direct (i.e., by axial expansion of (uel) or indi. rect (i.e., by longer-time-scate heating of the grid plate, resulting in radial expansion of the core). A negative Doppler effect is due to reduction of selfshielding in ${ }^{230} \mathrm{U}$ capture resonances with increasing temperature, causing an increase in neutron captures in the ${ }^{230} \mathrm{U}$. These capture resonances in "U are almost entirely below an energy level of about $25 \mathrm{keV}$. Thus the softer the spectrum in an LMFBR, the greater will be its Doppler effect.

In a small LMFBR such as EBR-II, the fuel cnrichment is relatively high (i.e., the "2n $U$ content is relatively omall) and the spectrum ia hard. The Doppler effect in such a reactor is small (and may even be positive) unleas considerable effort is made to degrade the neutron opectrum. For exumple. a mixed-oxide-fuel core in EBR-II was calculated ${ }^{52}$ to have a Doppler coefficient $\mathrm{r}(\mathrm{dk} / \mathrm{dT})=-2 \times 10^{-4}$, and such a core with 17 vol $\%$ BeO added for spectral soltening had a Doppler coefficient $=-2 \times 10^{-3}$. 
Inherent negative feedback reactivity in EBR- 11 : sion of fuel. sodium, and structural maierial. all having different time constants. The total isothermal temperature coefficient for EBR-II was calculated to be $-2.0 \times 10^{-3}(\Delta \mathrm{k} / \mathrm{k}) /{ }^{\circ} \mathrm{F}$." Tha prompt component (time constani $<-0.4 \mathrm{sec}$ ) of the isothermal coefficient was calculated to be about $-7.8 \times 10^{-6}(\Delta \mathrm{k} / \mathrm{k}) /{ }^{\circ} \mathrm{F}$. of which about $29 \%$ is due to axial expansion of fuel, and $64 \%$ to reduction in density of corc sodium. In a large LMFBR, the sodium-density effect would be expected to be small (and in the case of an oxide-fueled reactor to have a time constant of several seconds).

The Doppler coefficient in a large metal-fueled LMFBR is also sensitive to the amount, if any, of moderating material added. In the previously cited design study ${ }^{* \prime}$ of a 1000 -MWe metal-fueled reactor, calculations were done for berylliurn additions at the core radial-blanket interface and radialblanket/radial-reflector interface. Doppler coefficients [- T(dk/dT)] were found to range !rom 0.002 for no beryllium to 0.004 with beryllium at both incerfaces. An average value of 0.003 is used in Table XXVII. The Duppler coefficient in large oxide-fueled LMFBR's is calculated to be typically in the range of $0.007-0.009$; an average value of 0.008 is used in rable XXVII. Note that all the foregoing are "sodium-in" values, i.e., for no sodium los from the core. "Sodium-out" values would be lower.

The amount of axial expansion of oxide fue! in an LMFBR element under transient conditions depends in a complex manner upon the initial fuel density. fuel diameter. and $g$ ap between fuel and cladding. It also depends upon the linear power. burnup. cladding thickness, and temperature distribution of the sodium cooiant. At low burnips, hefore the fuel contacts the cladding, the fuel may expand freely if it has not undergone extensive cracking. Although the oxicle fuel has sower linear-expansion coefficient than its cladding by about a factor of two, it would heat up laster than the cladding during a rapid reac. tivily or now transient, because it has a lower thermal conductivity. Thus. the maximum axial expansion in an oxide element would occus if the oxide fuel cxpanded freely and coherently. Cracking. however. resulting from rapid shutdowns, ma) iead to the formation of spaces between pieces of fuel.

When the pieces of fuel tieat up. they expand intc the free spaces rither than expanoing coherently. Such effects were observed in RAPSODIE." Once the fucl contacts the cladding. it may be constrained to expand with the cladding. Since cladding temperature riseo are not expected to be large in a credible reactivity or Now tranaient, the reactivity feedback due to claddingcontrolled axial expansion of fuel is not expected to be large. For the foregoing reasons, the re has been a widespread coneensus that oxide fuel for an LMFBR does not have a well-characterized, rel able, axial-expansion coefficient of reactivity. "In Rel. 51, xero fuel-axial-expansion leedback reactivity was ireated as "the worbt asuumptions possible: the only negative leedback is the Doppler offect." That reference also sserts that "This combination (Doppler pius axial fuel growth restrained by the cladding! probably represents a minirnum amount of realistic negative leedback that can be expected during the transient." Following Ref. 55, however, zero axibl-expansion foedbeck is as sumed here for an oxide elemert. 
With regard to metal fuel, consider first the axial-expansion characteristic at burnups below that at which contact with the cladding occurs. Take

$$
\frac{d k}{d T} \quad \frac{d k}{d H / H} \cdot \frac{d H / H}{d T}-\alpha \frac{\Delta k}{\Delta H / H} .
$$

where $H$ is the core height and $\alpha$ is the average linear-expansion coefficient of the metal fuel in the temperature range of interest (here taken as 572 . $1292^{\circ} \mathrm{F}$ ). From thermal-expansion data given in Ref. 11 , a for U-15 wt \% Pu10 we $\% 2 \mathrm{r}$ is estimated to be $15.4 \times 10^{-6} /{ }^{\circ} \mathrm{F}$. This value includes expansion due to solid-state phase transformations in the interval $1103-1229^{\circ} \mathrm{F}$. As a point of interest, a for the U.5 F EBR-II fuel alloy is calculated from dilatometric data to be $15.2 \times 10^{-6} /{ }^{\circ} \mathrm{F}$ for the interval $572-1292^{\circ} \mathrm{F}$. 36 For this latter alloy, solid-state phose transformations occur in tho interval $1026-1337^{\circ} \mathrm{F} .96$

The change in reactivity per unit change in core height $[\Delta \mathrm{G} /(\Delta \mathrm{H} / \mathrm{H})]$.. and the associated reduction in fuel density--is taken to be the same as that used in Ref. 51 for the oxide core, namely. -0.158 . This value is close to values reported elsewhere for similar reactor configurations. ${ }^{53}$ Then. for unrestrained axial expansion of the ternary metal fuel alloy.

$$
-\frac{d k}{d T}=15.4 \times 10^{-6}: 0.158=2.4 \times 10^{-6} / . F .
$$

A compariton can now be made of the inherent prompt-negativefecdback reactivity available in the interval between normal operation and incipient failure for the oxide-and metal-fueled reactors. For the oxide-fueled reactor. the feedback is taken to be due only to the Doppler effect; i.e..

$$
-\Delta k_{\text {Dop }}=0.008 \ln \frac{3000+460}{2560+460}=1.09 \times 10^{-3} .
$$

For the metal-fueled reactor. the feedbesk is taken to be due to Doppler effect plus unrestrained axial expansion:

$$
\begin{aligned}
& -\Delta k_{\text {Dop }}=0.003 \ln \frac{1196+245+460}{1196+460}=4.1 \times 10^{-4} . \\
& -\Delta k_{\exp }=2.4 \times 10^{-6} \times 245=6.0 \times 10^{-4} .
\end{aligned}
$$

and

$$
-\left(\Delta k_{\text {Dop }}+\Delta k_{\text {exp }}\right)=1.01 \times 10^{-3} \text {. }
$$

Thus, If unrestrained axial expansion of all the metal fuel is ascumed, the metal-fueled reactor has about the ame inherent prompt-negative-feedback reactivity as the oxide-fueled reactor in the temperature range between normal operation and incipient failure. Of this, about $40 \%$ is Doppler feedback and $60 \%$ 
is axial-expansion feedback. In reality, however, the metal fuel will be at various burnup levels throughout the reactor. depending upon the power distribution, peak allowable burnup, ratio of the enrichments of the inner-and outer-core zones, and refueling scheme. As a worst hypothetical case, all the metal fusel would be in complete contact with its stainless steel cladding. with axial expansion controlled by the latter. Even if the transverse fuel-pin cracking described in Sec. IV. B occurs, the axial fuel expansion should follow the cladding expansion. Iaking the liriear-expansion coefficient of the stainless steel to be $11.0 \times 10^{-6} \mathrm{~F}$ in the temperature range of interest, we find that

$$
-c k_{i \times p}=6.0 \times 10^{-4} \times \frac{11.0}{15.4}=4.3 \times 10^{-4}
$$

and

$$
-\left(c k_{D o p}+\angle k_{\text {exp }}\right)=0.84 \times 10^{-3}
$$

Hence, for this worst hypothetical case, the metal-fueled reactor has $77 \%$ of the inherent prompt negative feedback. of the oxide-lueled reactor. These results suggest that the metal-and oxide-fueled reactors would place similar demands upon required response for a plant protection system and would provide similar feedback reactivity in a hypothetical unbounded reactivity transicnt.

\section{B. Olf-normal Reactor Operation}

The foregoing discussion focused upon inherent prompt-negativefocdback characteristics without regard to specific malfunctions and their as sociated time scales. That is, effects of heat loss from the fuel were not considered Such effects are important. however, in discussir; feedback reactivity for reactor malfunctions under the two general categories of transient overpower and loss of flow. It is in this context that the order-of-magnitude difference in time constants for metal and oxide fuel elements (see Table XXVII) becomes important.

In the temperature range of interest for most postulated credible accidents, the thermal conductivity of mixed-oxide fuel is small at normal operating temperatures and decreases with increasing temperature. This inhibirs heat loss to the cladding and the reby enhances the Doppler effect in the fuel and tends to reduce overheating of the cladding. However, the volumetric heat content $\overline{\rho C}_{p} \angle T$ (where $p=$ fuel density, $C_{p}=$ specific heat, and $\Delta T=$ average temperature risefrom normal operation to incipient failure) of the oxide fuel is almost twice as great as that of the metal fuel. This mitigates somewhat the Doppler effect in oxide fuel. (In other words, a given Doppler feedback in oxide fuel is obtained at the expense of about twice as much thermal energy stored in the fuel.) This thermal-conductivity effect is important 1or transients with time scales shorter than that of the time constant for the oxide fuel (. 3 sec), e.g. . for unbounded reactivity-insertion rates greater than about $0.3 \mathrm{~s} / \mathrm{sec}$. It is not important for how-coastown transients lasting about 1 min or longer. 
At low rates of inadvertent reactivity insertion (leading to relatively slow increases in power), long-time-constant inherent negative feedback reactivity due to such effects as grid-plate expansion and subassembly bowing would be of henefit in any LMFBR, regardless of fuel type. On the other hand, short-time-constant inherent negative feedback due to the Doppler effect and fuel axial expansion would he reduced in both metal-and oxide-fueled reactors because of the relatively long time available for loss of heat from the fuel. This argument also applies to loss-of-flow malfunctions that occur in time scales of the order of $1 \mathrm{~min}$.

As the reactivity-insertion rate increases, the long-time-constant feedback terms diminish in effectiveness. Under such conditions, however, the prompt feedback reactivity in the metal-fueled reactor is slower to approach its limiting adiabatic value than is the corresponding reactivity in an oxidefueled reactor. This is simply because the time constant for heat transfer in the metal fuel is about a factor of 10 smaller. The increase in power, which is determined by the net reactivity added, would thus be expected to be more rapid in a metal-fueled reactor than in an oxide-fueled reactor for a given inadvertent unbounded reactivity-insertion rate.

Slumping of metal fuel (shortening by creep under its own weight) under normal operating conditions during long irradiation times was discussed in Sec. V.C. Slumping or compaction of such fuel under hypothetical accident conditions must also be considered. During irradiation, the metal fuel swells both radially and axially within its cladding (see Sec. IV). Assume that a metal-fueled reactor containing a large amount of swollen fuel is operating normally and then undergoes a transient leading to overheating of the fuel. The question then arises as to whether rapid compaction of the swollen fuel will take place, leading to potentially large rates of reactivity insertion.

In the EBR-II Mark-II metal-fuel design, 33\% fuel swelling is allowed; at $25-30 \%$ swelling, interconnection of porosity occurs. There are two important safety aspects of the interconnerted porosity. First, it allows about a $60 \%$ fission-gas release from the fuel. Second, it allows thermal-bond sodium to move into the porous fuel and $\log$ it. Thus, if high-burnup metal fuel overheats, it should not literally explode, as it might if it contained large amounts of fission gas. Nor would it be expected simply to slump rapidly into a more reactive geometry as it approached its melting point. This is because the U15 wt $\% \mathrm{Pu}-10$ wt $\% \mathrm{Zr}$ alloy begins to melt at about $2110^{\circ} \mathrm{F}$, but at this temperature, the logged bond $g$-tium would have a vapor pressure of $7.3 \mathrm{~atm}$ absolute. The logged sodium would thus tend to have a dispersive effect on the fuel column, at least in the early stages of a transient. Subsequent fuel motion, involving the potential for recriticality, is a complex problem that probably would require transient reactor tests and supporting analysis for solution.

A metal fuel element contains sodium as a thermal bond. Consequences of $108 \mathrm{~s}$ of the bond have been considered extensively for the metal driver fuel in EBR-II. The following summarizes the results of some tests of elements containing a partial bond or no bond. ${ }^{57}$ 
An element with a partial circumferential bond has been tested at TREAT (EBR-MF-1) in a test simulating steady-state power in EBR-II. The element was fully bonded in the lower $4.5 \mathrm{in}$. of its length while the upper 9 in. had a partial circumferential bond of $180^{\circ} \pm 50^{\circ}$. The element was subjected to a flat-topped transient in TREAT with peak powers of $420 \mathrm{~W} / \mathrm{g}$ and an average power of $290 \mathrm{~W} / \mathrm{g}$ (equivalent to a reactor power of $85 \mathrm{MWt}$ in row 1). The postirradiation results indicated no fuel-cladding eutectic formation, no cladding strain, and little change in the pin diameter. The data indicated that the fuel was heated above $642^{\circ} \mathrm{C}$, the transformation temperature for $\alpha$ to $\gamma$ phase, but was not heated to its melting temperature $\left(1002^{\circ} \mathrm{C}\right.$ for solidus).

Element EBK-MF-2, which contained a partial axial bond, was also tested in TREAT. The element was made with a complete bond in the lower 3.6 in., a partial bond for the next 4.1 in., and no bond for the upper $5.8 \mathrm{in.}$ The element was subjected to a flat-topped transient in TREAT for an average power of $308 \mathrm{~W} / \mathrm{g}$ (equivalent to a reactor power of $88 \mathrm{MWt}$ in row 1). Posttest examination indicated that the upper section of the fuel had contracted $0.6 \mathrm{in}$. Straining of the cladding occurred in the unbonded areas, with a maximum diameter increase of 0.0005 in. $0.3 \% \Delta \mathrm{D} / \mathrm{D}$ !. Examination at the $9 \frac{1}{2}-$ in. level and at the top of the pin indicated that liquid fuel had been in contact with the cladding. For most of the fuel, however, melting occurred only at the grain boundaries, the location of the lowest melting uranium alloy composition. The liquid fuel in contact with the cladding had reacted with part of the cladding to form a liquid eutectic alloy. The maximum reduction in the nominal 0.009-in. wall thickness was 0.002 in. At the center of the fuel, the grain structure indicated that the fuel had become molten only at the grain boundaries and that all of the fuel had not melted.

Tests ID-RP-1 and ID-RP-2 were conducted on elements with no sodium bond. The elements were subjected to flat-topped transients in TREAT to power densities of 170 and $270 \mathrm{~W} / \mathrm{g}$, respectively. For the former test, local fuel-cladding eutectic formations occurred, with the maximum penetrations being less than 0.001 in. For the latter tests, the maximum eutectic penetration was about 0.001 in.

In all of the above tests, the flat-topped transient allowed the elements to be at a relatively level power for about $8 \mathrm{sec}$. The power ratings were high enough so that fuel for the unbonded elements would have reached its melting temperature, slumped, and recast against the side of the element and run at equilibrium conditions at the end of the test. There was no cladding failure in any of the tests, even though there were areas of local fuel-cladding eutectic formation.

In more recent tests, ${ }^{58}$ a special subassembly, $X 149$, containing 12 partially bonded EBR-II Mark-IA driver-fuel elements was irradiated in EBR-II during run 59A to an exposure of $74 \mathrm{MWd}$. Eight of the elements contained 
partial axial voids in their bond sodium, and four contained partial circumferential voids in theirs. Neutron radiog raphs of the 12 elements made subcequent to the irradiation indicated that all the elements containing axial voids had significant amounts of fuel me!ting in the upper 5 in. of the fuel pins. All the elements containing circumferential voids showed little change, except for small sections along the centerline of the fuel pins, where melting apparently started. No penetiation of the cladding was observed in any of the 12 elements, and they were judged suitable for reinsertion into EBR-II for further irradiation. Reconstituted as experimental subassembly X149A, the subassembly was irradiated in EBR-II in runs 69A-74G, totaling $11,306 \mathrm{MWd}(-2.1$ at. \% burnup). During this interval, it gave no evidence of fission-gas release or bond-sodium release. All the foregoing work supports the kelief that substantial debonding of a metal-fuel element will not lead to breaching of its cladding.

In the highly unlikely event of a reactor malfunction leading to breaching of cladding by molten metal fuel, however, the potential for molten-fuel/ coolant thermal interaction (MFCI) must be considered. Fauske ${ }^{59}$ has proposed that a necessary, but not sufficient, condition for a vapor explosion to result from an MFCI is that the interface temperature between the "hot" and "cold" liquids must be greater than the homogeneous nucleation temperature of the "cold" liquid. For sodium as the cold liquid, Fauske reports that the nucleation temperature has been found experimentally to be $2300^{\circ} \mathrm{K}$. The interface temperature is defined by

$$
\frac{T_{H}-T_{I}}{T_{I}-T_{C}}=\sqrt{\frac{\left(\rho k C_{P}\right)_{C}}{\left(\rho k C_{P}\right)_{H}}}
$$

where

$$
\begin{aligned}
\mathrm{T} & =\text { absolute temperature } \\
\rho & =\text { density } \\
\mathrm{k} & =\text { thermal conductivity, } \\
\mathrm{C}_{P} & =\text { specific hedt, } \\
\mathrm{H} & \equiv \text { hot liquid, } \\
\mathrm{C} & \equiv \text { cold liquid, }
\end{aligned}
$$

and

$$
I \equiv \text { interface. }
$$

When we use the estimated properties for molten U-5 Fs alloy (that used for $E B R-i I$ driver fuel) and $T_{I}=2300 \%$, the foregoing equation gives $T_{H}$ as a function of $\mathrm{T}_{\mathrm{C}}$. For $\mathrm{T}_{\mathrm{C}}=1000^{\circ} \mathrm{K}\left(1340^{\circ} \mathrm{F}\right), \mathrm{T}_{\mathrm{H}} \approx 2560^{\circ} \mathrm{K}\left(4148^{\circ} \mathrm{F}\right)$. This temperature is $2000^{\circ} \mathrm{F}$ above that at which the metal fuel is completely molten. Thus, before temperatures high enough to cause an $\mathrm{MFCl}$ with metal fuel would be reached, other potentially more serious problems would arise, e.g., rapid rearrangement of fuel. 
The foregoing comparison of the behavior of la rge metal-fueled and oxide-fueled LMFBR's was admittedly qualitative. A quantitative comparison could only be made after doing calculations of loss-of-flow and overpower transients for each type of reactor. These calculations should be done on as consistent a basis as possible, using appropriately justified fe edtack-reactivity coefficients, criteria for incipient failure of fuel elements, etc. Results of the calculations would show any significant differences in plant-protection-system and containment requirenients for the two reactor types.

\section{Conclusions on Safety Considerations}

1. Under off-normal reactor operating conditions, the controlling mechanism for element failure appears to be cladding penetration by fuel for metal-fuel elements and sodium boiling for oxide-fuel elements.

2. For the interval between normal operating conditions and incipient failure of elements, the prompt negative feedback reactivity due to both axial expansion of fuel and the Doppler effect in a large metal-fueled LMFBR is about the same magnitude as that due to the Doppler effect alone in a large oxide-fueled LMFBR.

3. Large metal- and oxide-fueled LMFBR's will have similar plantprotection-system requirements with regard to response characteristics.

4. To obtain a given amount of Doppler feedback reactivity, the thermal energy stored in the fuel of an oxide-fueled reactor must be twice as much as that stored in the fuel of a corresponding metal-fueled reactor.

5. For a given inadvertent unbounded reactivity-insertion rate, the increase in power woild be expected to be more rapid in a metal-fueled reactor than in an oxide-fueled reactor.

6. Overheating of high-burnup metal fuel would not be expected to lead to rapid fuel compaction and potentially large rates of reactivity insertion; however, both out-of-pile and in-pile tests would probably be required to prove this.

7. Results of a number of in-pile (TREAT, EBR-II) tests indicate that substantial debonding of a metal fucl element will not lead to breaching of its cladding.

8. With metal fuel, molten-fuel/coolant interaction would only become explosive at temperatures at which a more serious problem would be likely to occur, namely, extensive compaction of the core.

9. Analyses should be done to provide a quantitative basis for comparing the safety-related characteristics of large metal-fueled LMFBR's with those of large oxide-fueled LMFBR's; such work should use consistent reactor configurations, operating conditions, material properties, hypothetical malfunctions, etc. 


\section{APPENDIX \\ Properties of U-Pu-Zr Fuel Alloys}

This appendix summarizes in tabular form the available pertinent information on physical and tensile properties of $\mathrm{U}-\mathrm{Pu}-\mathrm{Zr}$ alloys. For compar ison, information is also presented on other metallic fuels.

TABLE XXVIll. Phyeical Propertieg of $1 !-P u-Z r$ Alloye24,19.46

\begin{tabular}{|c|c|c|c|c|c|}
\hline \multirow[b]{2}{*}{ Property } & \multicolumn{5}{|c|}{ Alloy, ut \% } \\
\hline & $\mathrm{U}$ & $\mathrm{U}-5 \mathrm{~F} \mathrm{~s}$ & $U-11 \mathrm{Pu}-6 \mathrm{ZT}$ & $\mathrm{U}-15 \mathrm{Pu}-10 \mathrm{Zr}$ & $\mathrm{l}-18 \mathrm{Pu}-1+2 \mathrm{r}$ \\
\hline Liquidus temp. $F$ & 2070 & 2160 & -2190 & -2280 & -2350 \\
\hline Solidus temp. ' $r$ & 2070 & $18 ? 2$ & -2050 & -2110 & $-21+0$ \\
\hline $\begin{array}{l}\text { Transformation tomp. F } \\
\text { Start } \\
\text { Complete } \checkmark\end{array}$ & $\begin{array}{l}1234 \\
1427\end{array}$ & $\begin{array}{l}1026 \\
1: 33\end{array}$ & $\begin{array}{l}1163 \\
1256\end{array}$ & $\begin{array}{l}1103 \\
1229\end{array}$ & $\begin{array}{l}1103 \\
1220\end{array}$ \\
\hline Density at it $F$ (as $(a a t) . g / \mathrm{cm}^{3}$ & 19.1 & 18.0 & 16.8 & 15.8 & 14.8 \\
\hline $\begin{array}{l}\text { Average coefficiert af inermal } \\
\text { expansion, } 10^{-6}, F\end{array}$ & & & & & \\
\hline $\begin{array}{l}77^{\circ} F \text { to first transformation } \\
\text { Find of transformation } 101742 \mathrm{~F}\end{array}$ & $\begin{array}{l}10.8 \\
12.8\end{array}$ & $\begin{array}{l}4.2 \\
b\end{array}$ & $\begin{array}{l}10.2 \\
10.1\end{array}$ & $\begin{array}{l}9.8 \\
11.2\end{array}$ & $\begin{array}{l}9.7 \\
11.1\end{array}$ \\
\hline $\begin{array}{l}\text { Fractional length increase in } \\
\text { tranaformation range. Al ? }\end{array}$ & $0.00+5$ & 0.0059 & 0.0051 & 0.0052 & 0.0050 \\
\hline $\begin{array}{l}\text { The rmal Conductivity } \\
\left.\text { al (ac) (cm) } t^{\circ} \mathrm{C}\right) \\
\text { at } 230^{\circ} \mathrm{F} \\
\text { at } 1640 \mathrm{~F}\end{array}$ & $\begin{array}{l}0.069 \\
0.127\end{array}$ & $\begin{array}{l}0.0+8 \\
0.120\end{array}$ & - & $\begin{array}{l}0.031^{c} \mathrm{c} \\
0.076^{\mathrm{c}}\end{array}$ & $\dot{-}$ \\
\hline DIll llardness at 77 f (as cast) & 290 & $21+$ & +70 & 540 & +10 \\
\hline
\end{tabular}

a Dac to $1+72$ r only.

biri dala avai!able for tomperatures above eraneformation temperature of $1337^{\circ} \mathrm{F}$.

Clita for 1 - 15 ut \% Pu-6.8 ut \% Zr.

TASLE XXIX. Tensile Properties of Extruded L. 15 wi \% Pu-10 wit Z Zr (Ref. 35)

\begin{tabular}{|c|c|c|c|c|}
\hline $\begin{array}{c}\text { Temperature } \\
F\end{array}$ & $\begin{array}{l}\text { ('llimate Tenaile } \\
\text { Strength, } 10^{3} \text { pai }\end{array}$ & $\begin{array}{l}\text { Yield Strength } \\
\text { (at } 0.2 \% \text { off-net). } \\
10^{3} \mathrm{p}=\mathrm{i}\end{array}$ & $\begin{array}{c}\text { Elongation. } \\
\end{array}$ & $\begin{array}{c}\text { Elaeticity, } \\
10^{\circ} \mathrm{pai}\end{array}$ \\
\hline 77 & 70 & - & Nil & 2.2 \\
\hline 570 & 39 & - & Nil & 2.1 \\
\hline 660 & +4 & $4 t$ & 3 & 0.9 \\
\hline 750 & 14 & 10 & 53 & 0.4 \\
\hline
\end{tabular}




\section{ACKNUW LE DGMENTS}

The asaistance of the following people is gratefully acknuwledged: G. J. Bernstein, R. M. Fryer, A. G. Hins, J. H. Kittel, and M. J. Steindler for their technical review and suggestions on various sections; J. E. Flinn.

G. L. Hofman, and J. F. Koenig for allowing our use of unpublished data; and K. J. Mudge for aid in preparing the refort. 


\section{REFERENCES}

1. J. H. Kitcel ex sl., Plutunium and Plutonitum Alioys as Hucleas fliel Materiala, Nuc1. Eng. Design 15(4), 373-440 (May 1971).

2. N. J, Olson and G. C. Mcclellan, Interim kesults of End-of-Life Erarina.tion of Mark-IA Pue? Irradiatad in EBR-II Subassembly X06BA, ANL/ELA-06y (Feb is?3).

3. N. J. Olson, C. M. Walter, and W. N. Beck, Statilatical and Metallurgicai Anaiyses of buperimental Hark iA Driver suel Element Cladding Failures in the Experimentoi Breeder Reactor II, Rucl. Technol. 2b(1), 134-151 (Jan 1976):

4. R. S. Barnes, A Theor, of Swelling ani Gas Release for Keactor Matarials, J. Nuc! . Mater. 11(2), 135-148 (Mar 1964).

5. Reuctor Development Progmur Progrees Report: Novamber 1973, NuL-RDP-22, P. $1.22(\tan 8,1974)$.

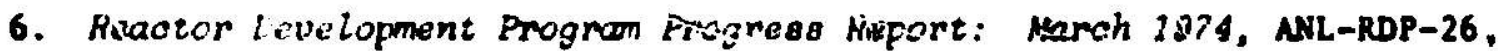
p. 1.19 (Apr 26, 1974).

7. 3. P. Bacca, F. G. Foote, G. C. MCClellan, and J. H. Cunk, Performance of EBK-II intuey Puel, Trans. Am. Nucl. Soc. 12(1), 90 (June 1969).

8. W. F. Murphy et al. Postirradiation Exemination of U-PU-2r Fuel Elemerste irraciated in EBR-II to 4.5 Atamic Percent Bumup, ANL-7602 (Dec 1969).

9. H. N. Beck, R. J. Fousek, and J. H. KAteel, The Irradiation Buhavior of Hi.gh-bumuf, Urunilon-Plutoniun Alloy Srototype Fuel Eiemsnto, NR-7388 (May 1968).

10́. S. A. Caspersson, R. C. Noyes, and J. A. VitC1, "Econonic and Nuclear Perfozance Character1st1ce of $500 \mathrm{mH}(e)$ Oxide, Carbide, and Nitride LYPBRs," Prat. Int. Conf. on Advanced Reactors: Physics, Design and Ecunomics, Atlante. Sspt 8-11, 1974, J. M. Kallfelz et al., Eds.. Pergamon Preas, Pp. 125-1.34 (i9?5).

11. W. N. Beck et al., Irradiation Ferformance of Fust Reactor UranizonPlutoniwn Metal Fuele, Nucl. Met. 13, 507-523, A. iner. of Mining, Metallurglcal, and Petrolel Englneers (1968).

12. C. M. Walter, N. J. Olaon, and C. A.. Hofmen, BBK-II Driisr Fuel Qualification and Performance, Nucl. Met. 18, 181-202, Am. Inst. of Mining. Metallurgical, and Petroleun Enginears (1973).

13. Reactor Deve Lopnant Progran Progrese Report: Nanch 1974, All-Rop-26, p. 1.21 (Apr 26, 1974).

14. G. L. Hofmen el. Irradiation Behruior of Unencesoulated EBR-II Mark-II Driver Puti. to a Marimen Bumup of 6 at. 5 , An-8119 (Fab 1976).

15. J. F. Koen18, EBR-Il Project, pareonal comandcat1on (Apr 1975).

16. W. Halbull, A Statistical Distribution Punstion of Wide Applioability, J. Appl. Mech. 18, 29.1-297 (1951).

17. H. P. Goode and J. H. X. Kao, "An Mdepsation of the MIL Standerd 105B Plans to Rallability and Life Teotins Applicet1on," Trano. Am. Soo. for Quality Control 15th Anual Convention, PItevburgh, June 5-7, 1961. pp. 245-251. 
19. H. Swith and S. D. Dubey, reme Reliability brublems in the Chemical Ina.'stry, Indus. Qual. Control ii(2): 64-70 (Aug 1964).

19. A. j. Fitzelberger, Improve your Reliability, lbiú, ?4(6), 313-316 (Dec 19:57).

20. J. A. Mrretton1, Practical Application of Weibuli Viatribution, op. c1t. 21(2), P-ip (Aug 1964).

21. R. A. Milchell Ints..jetion to Weibull Analyaiy, PWA 3001, Pratt and Whitney Alrcraft 3001, U1: , of Un:ted Alrcreft Corp., East Hartford, Conn. (Jan $6,19 \bar{i} i)$.

22. J. L. Jeeci, Exxon Nuclear Corporatic:, persoral ccmonication (Har 1971).

23. L. G. Johnion, Thiory and Tachique of Vari tion Research, Elsevter, New York, ip. 2 and 61 (1964).

24. Reactor Devilopment Progrom Progress Report: Novemi-n 1973, ANL-RDP-22, p. $1.26(\mathrm{Js}, 8,1974)$.

25. L. R. Kelman, H. Savage, C. M. Walter, B. Blumenthal, R. J. Dunworth, and H. V. Rhude, "Status of Metall1c Plutonium Fast Power-Breeder Puels," Proceedings of the Third Intermatiora? Conference on Plutonicon, Plutonium 1965, A. E. Kay and M. B. Waldron (Eds.) for the Inst1tute of Metels, UKAEA, Chaplan and Hall, PP. 458-526, London (1965).

26. Reactor Development. Proymom Progre日8 Report: April-May 1969, ANL-757i. p. 152 (July 7, 1969); June 130人, ANL-7581, p. 90 (July 29, 1969); July i969, NNL-7595, p. 96 (Aug 25, 1959): August 1969, ANL-7506, p. 99 (Sept 26, 1969); and Septeinber 1969, ANL-7618, D. 94 (Oct 24, 1969).

27. S. T. Zegler and C. M. Walter, Compatibility between Metálic UroniumPlutonium-Base Fuflo and Potentiai Cladding Materials, Nucl. Met. 13, 335-344, Am. Inst. of Mining, Metallurgical, and Petroleum Engineers (1968).

28. S. T. Zegler, H. V. Riude, and J. A. Laht1, Compatibility of Uronium-5 w/O Fiseiwn Alloy with Types 30 iL and 316 Stainlese Steel, ANL-7596 (Sept 1969).

29. C. M. Walter and J. A. Laht1, Compatibility of Uramizon-PLutoniwi-Zirconium Fuel Alloys with Potential Cladding Naterials, Nucl. Appl. 2, 308-319 (Aug 1965).

30. M. Hansen, Constitution of Binary AZZOzB, McGraw-H111, New York (1958).

31. P. G. Mardon et al., The Plutoniwm-Iron System, J. Inst. Met. 86, 166-171 (Dec 1957).

32. C. M. Walter and L. R. Kelman, Penetration Rate Studies of Stainlese Steel by Molten Uranizon and Uranium-Fiseivm Alloy, J. Nucl. Mater. 6(3), 281-290 (1962).

33. C. M. Walter and C. E. Dickerman, TREAT Study of the Penetration of Molten Uranium and U-5 wt $\$ \mathrm{Fe}$ Alloy through Type 304 Stainlese Steel, Nucl. Sc1. Eng. 18, 518-524 (1964).

34. C. M. Walter and L. R. Kelman, The Interaction of Iron with Molten Urconium, J. Nucl. Mater. 20(3), 314-322 (1966);.

35. D. R. Harbur, J. W. Andersan, and W. J. Maraman, Studies on the U-Pu-Zr Alloy Syotem j:yr Fast Breedar Reartor Applications, iA-4512 (1970). 
36. H. A. Saller, K. F. Dlckerson, A. A. Bauer, and N. F. Daniel, Properties of a Fisaium Type Alloy, BMI-1123 (Aug 3, 1956).

37. B. Blumenthal, The Transformation Temperchures of High Purity Uraniwm, J. Nuil. Mater. 2(1), 23-30 (1960).

3e. A. S. Coffinberiy and M. B. Waldron, "The Physical Metallurgy of Plutonlum," Progress in ivicicar Energy, Serles V, Vol. I, Pergamon Press, Pp. 354-410, London (1956).

39. W. N. Beck and R. J. Fousek, Fission Grs Release and Thermal Conduciivity Measurement on $\|-5$ wt $\% F s$ Irradiated in CP-5, Trans. Am. Nucl. Soc. $12(1), 78$ (1969).

40. H. F. Jelinek, N. J. Carson, Jr., and A. B. Shuck, Fabrication of EBR-II, Cripe-l Fuel Pins, ANL-6274 (June 1962).

i1. N. $\rightarrow$. Carson et al., Fabrication of EBR-II, Core I Fuel Elements, ANL-6276 (Dec 1962).

42. 31, J. Feldman at al., Remote Refabrication of EBR-II Fuels, Nuc1. Met. 15. $1 i, 2.5$. Intt. of Mining, Metallurgical, and Petroleum Engineers (1969).

43. H. F. Jelinek and A. G. Hins, "Fabrication of Experimental Metal Fueled Irradiation Test Rods," Arwinl Progress Report for 1965: Metallurgy Diviaion, ANL-7155, pp. 66-68 (1956).

44. E. F. Sturcken and C. M. Walter, Texture and Irradiation Growth in EBR-II Driver Fuel, J. Nucl. Mater. 50(1), 69-82 (Feb 1964).

45. S. Lawroski and L. Burr1s, Jr., Processing of Reactor Fuel Materials bij Pyrometallurgical Methods, At. Energy Rev. 2(3), 3-69, IAEA Vienna (1964)

46. D. C. Hampson, R. M. Fryer, and J. W. R1zz1e, MeZt Refining of EBR-II Fuel, Nucl. Miet. 15, 57, Am. Inst. of Mining, Metallurgical, and Petroleum Eng1niaers, (1969).

47. I. 0. Winsch et al., EBR-II Skull Reclamation Process, Ibid., p. 77.

48. L. E. Link et a., 1000-MW(e) Metal-fueled Fast Breeder Reactor, ANL-7001 (June 1966).

49. R. L. Stevenson and P. E. Sm1th, "Aqueous Separation," Ch. 4 of Vcl. I, Fuei Reprocesining, Reactor Handbook, S. M. Stoller and R. B. R1chards, Eds., Pp. 107-2.34, Intersclence Pub., Inc., New York (1961).

50. W. Ochsenfeid, H. Schsleder and S. The1ss, Aqueous Repmcessing of Fast Bresder Fue? Ëzments-Common Extraction and Separation of Macroquantities of Plutonizon and Uronium in the Purex Proces8, KFK-911, Karlsruhe Nuclear Research Center, EUKFNR-888 (Oct 1970).

51. Comparison of Two Sodium-Cooled, 1000 MWe Fast Reactor Concepts, Task I Report of 1000 MWe LMFBR Fcllow-On Work, GEAP-5618 (June 1968). (Data for advanced plant used here.)

52. G. H. Golden and B. R. Sehgal, Thermal-Hydraulic and Doppler Characteristics of Some Oxi.de Cores for EBR-II, Trans. Am. Nucl. Soc. 12(2), 916 (Dec 1969).

53. L. J. Koch, W. B. Loewenste1n, and H. O. Monson, Addendum to Hazard Summary Report, Experimental. Breeder keactor-II (EBR-II), ANL-5719 (Addendum) (June 1962). 
54. J. M. Chaumont, M. Jallade, and J. Martin, "Information on the Behavior of tise Oxide Fuel Drawn from Observations of the Reactivity During the Flrst Days of Power of RAYSOD!E-FURTISSIMO," Proc. ANS "of ical Neeting Irradiation Experimentation in Fast Fieactor,, Jackson, Wyo., Sept. 10-12, 1973. pp. $484-488$.

55. H. H. Humel and D. Okrent, Reactivity Coofficients in Lurge laet Power Reactors, Monograph Series on Nuclear Sclence and Technology, John Graham, Ed., Am. Nucl. Soc. (1970).

56. S. T. Zegler and M. V. Nev1tt, Structures and Properties of Uranium-fiosium Alloya, ANL-6il6 (July 1961).

57. J. F. Koen18, C. C. Ford, and A. A. Madson, Argonne Nat Ional Lavoratory, unpublished Information (1971).

58. J. F. Koen18, EBR-II Project, perscnal communication (June 1975).

59. H. K. Pauske, Some Aopecte of Liquid-Liquid Heat Transfer and Explodive Boiling, Proc. Fast Reactor Safet: Meeting, Betinily Hills. Callf., April 2-4, 1974 CONF-740401, P2, Pr. 99;-1005. 